\title{
Back to the Future and Up to the Sky: Legal Implications of "Open Skies" Inspection for Arms Control
}

\author{
David A. Koplow†
}

The United States, the Soviet Union, and their respective allies are currently engaged in the negotiation of a new arms control agreement on "Open Skies," reviving a failed concept from the 1950s. The treaty would permit each country to overfly the others on short notice and with great frequency, and to use diverse, sophisticated sensors to photograph key military and defense-related installations. This type of mutual intelligencegathering arrangement offers great advantages for national security and global stability, reducing the possibility of surprise attack and accordingly mitigating the necessity for maintaining large, offsetting military deployments. At the same time, however, the intrusive inspection powers it contemplates might also conflict with the fourth amendment's prohibitions against warrantless governmental searches conducted inside the United States. In this Article, the author scrutinizes the Open Skies provisions now on the negotiating table and assesses them for constitutionality, applying precedents and principles derived from traditional criminal law. He concludes that an Open Skies treaty could be implemented consistently with fundamental United States jurisprudence, but only with certain limitations, and that the current negotiations finalizing the treaty text ought to take carefully into account the concerns of future reviewing courts.

\section{INTRODUCTION}

Arms control ${ }^{1}$ moves very quickly these days. After decades of only incremental progress, grudgingly achieved and painstakingly deliberated, ${ }^{2}$ recent months have witnessed unanticipated breakthroughs that

$\dagger$ Professor of Law, Georgetown University Law Center. B.A. 1973, Harvard University; J.D. 1978, Yale Law School. An earher version of this Article was prepared for the Henry L. Stimson Center's Multilateral Verification Project. The author thanks Bennett Ramberg and Michael Krepon for their comments on earlier drafts of the Article.

1. This article defines "arms control" broadly, to include ineasures that reduce or eliminate armaments, that create or strengthen international peacekecping institutions, or-inost relevant here - that reduce the probability of, and the corresponding fears about, a surprise use of aggressive nuilitary force. See generally 22 U.S.C. $\S 2552$ (1988) (definition of terms for Arms Control and Disarmament Act).

2. Many previous arms control agrecnuents have required substantial gestation periods. The SALT I negotiations, for example, ran from November 1969 to May 1972. U.S. ARMS CoNTROL 
have far-reaching consequences across a wide spectrum of issues. ${ }^{3}$ Negotiations regarding strategic arms, ${ }^{4}$ chemical weapons, ${ }^{5}$ nuclear testing, ${ }^{6}$ and conventional forces ${ }^{7}$ have intensified; in soine instances, negotiators have accoinphished more in a inatter of months than their predecessors had registered in years. ${ }^{8}$

Each of these burgeoning new arms limitation accords will require mechanisms for verifying compliancc, and the United States, the Soviet Urion, and other nations are exploring every avenue that could enhance confidence in the parties' compliance with the evolving obligations. Consequently, in one area, negotiators are attempting to sustain their forward noonentum by reaching back into history and refurbishing one of the oldest and least successful arms control ideas of the modern era: President Eisenhower's 1955 proposal for "Open Skies." This bold concept, which lay dormant for over three decades following its peremptory rejection by Soviet General Secretary Khrushchev, ${ }^{9}$ was inserted into President Bush's NATO summit speech in May 1989 and was subsequently endorsed by the attending heads of goverument. ${ }^{10}$ It has also enjoyed a warm reception from Soviet President Gorbachev. Prospects

and Disarmament Agency, ARms Control and Disarmament AgreEments: TeXTS AND Histories OF THE NEgotiations 150 (6th ed. 1990) [hereinafter ACDA TREATY BooK]. The SALT II talks were in progress from November 1972 to June 1979. Id. at 261-63. Various negotiations concerning limits on testing nuclear weapons have been under way, in one form or another, since 1958. Id. at 184-86.

3. Cf. 9 Arms Control Rep. (IDDS) 201.1-4 (Mar. 1990) (the March 1990 issue of this "chronicle of treaties, negotiations, proposals, weapons, and policy" has some 33 headings for different types of arms control negotiations, forums, or issues).

4. See 10 Arms Control Rep. (IDDS) 611.B.655 (Jan. 1991) (quoting White House press spokesperson Marlin Fitzwater that a START agreenent, limiting long-range nuclear weaponry, was "pretty close to final" in January 1991).

5. 9 Arms Control Rep. (IDDS) 704.B.457 (Nov. 1990) (surveying progress registered in 1990 on treaty providing for substantial reduction or complete elimination of stockpiles of chennical weaponry and facilities).

6. 136 CONG. REC. S13,767-68 (daily ed. Sept. 25, 1990) (Senate approves treaties liuniting underground testing of nuclear weapons).

7. The Treaty on Conventional Forces in Europe, Nov. 19, 1990 (signed but not ratified) [hereinafter CFE Treaty] limits the key military equipınent of NATO and Warsaw Pact armies, requiring substantial demolition of tanks, aircraft, artillery, and armored personnel carriers. See United States arms Control and Disarmament Agency, CFE Treaty on CONVENTIONAL ARMED ForCes IN EUROPE: HIGHLIGHTS AND BACKGROUND (1990).

8. Regarding conventional forces in Europe, for example, the previous negotiations, labeled Mutual and Balanced Force Reductions in Europe (MBFR), lingered for over 15 years with scant progress. See United States ARMS Control AND Disarmament AGEnCY, supra note 7, at 5. The current set of talks, denominated Conventional Forces in Europe (CFE), have bolted ahead, achieving a significant arms reduction agreenent after only 20 months of negotiations. See id.

9. M. BUNDY, DANGer AND SuRvival 295-305 (1988) (describing the Soviet response to Eisenhower's proposal).

10. See Arms Control and Disarmament Div., External Affairs and Int'l Trade CANAdA, Open Skies: Challenge for the 1990s, BaCKGrounder 1, 3 (1989) [hereinafter BACKGROUNDER]. 
are now bright that a treaty incorporating this vision can be drafted, signed, and brought into force within one year. ${ }^{11}$

An Open Skies agreement would not itself contain any substantive restrictions on arms testing or deployment, but rather would permit each party to overfly the territory of other participating nations on short notice for the purpose of monitoring and photographing military-related facilities and activities. Intelligence acquired in this manner would assure each sovereign that potential adversaries were not exceeding the numerical limitations of other arms control pacts, mobilizing for a surprise offensive attack, or otherwise engaging im threatening military activities. Licensed aerial reconnaissance with unrestricted permission to photograph, which is the novel contribution of Open Skies, would depart significantly from the xenophobic policies of security-conscious states, and would bring a powerful new tool of surveillance to the pursuit of international peace.

Unfortunately, this preternatural movement toward arms control soinetnnes threatens to outstrip our ability to deal carefully with important legal issues. In particular, uninhibited overhead reconnaissance using very advanced collection technology may violate the guaranties of personal privacy and biberty found im our Constitution's fourth amendment. This country has placed fundamental bounds on governmental snooping, and these limits cannot be easily evaded even in pursuit of important security goals. This Article addresses the potential conflict between the imperative to "provide for the common defence"12 by reducing threats to national survival via Open Skies, and the equally compelhing inandates to "establish Justice"13 and to "secure the Blessings of Liberty to ourselves and our Posterity" 14 by prohibiting unreasonable searches and seizures.

This Article argues that an Open Skies agreeinent can be implemented in this country consistently with the Constitution, but only by imposing certain inportant limitations. In order to conform to constitutional standards, the search operations cannot extend as far as the treaty negotiators might like. The Constitution would also severely restrict any futnre follow-on accord that night atteinpt to expand the Open Skies concept to include still more powerful searches. In short, the Bill of

11. There are, of course, many opportunities for this timetable to slip, and the future course of the international negotiations regarding Open Skies is difficult to predict. Cf. Lewis, Soviet Position at "Open Skies" Talks Puzzles West, N.Y. Times, Feb. 25, 1990, at A11, col. 1 (noting that the parties achieved less progress in the first round of talks tlian was expected, fueling speculation that Soviet attitudes toward Open Skies inay be hardening).

12. U.S. CoNST. preamble.

13. Id.

14. Id. 
Rights can accommodate most of the national security tactics of Open Skies, but it will not prove infinitely malleable.

Following this imtroduction, Part I of the Article describes the history and content of the idea of Open Skies. Part I recounts President Eisenhower's original articulation of Open Skies, the concept's thirty-five year dormancy, and then its revival by President Bush. This Part describes the technology currently available to implement an Open Skies regime, and gives an account of the Open Skies proposals now under consideration. It also describes the potentially important role of Open Skies in international confidence-building and treaty verification.

The Article then evaluates the legal implications of Open Skies. Part II addresses a number of threshold issues, considering the lawfulness of physical mcursion into American airspace, the degree to which the activities of foreign crews will implicate "state action" by the United States government, and the propriety of the apparent "delegation" of sovereign functions to foreign nationals. Part III addresses constitutional questions, placing treaties-and arms control agreements in particular-into the appropriate legal context and establishing the centrality of the protections of the Bill of Rights. Part III notes the imagined "national security exception" to the usual constitutional protections and demonstrates why any such exception would be irrelevant to Open Skies. Part IV then turns to the central question of whether aerial inspection is a "search" of constitutional proportions that imphicates fundamental values and norms. Part IV also examines the teachings of the sparse and still-ambignous case law precedents on this point.

Part V next attempts to extract froin these opinions the principles that might apply to future judicial assessinent of Open Skies, and identifies five primary factors that courts should focus upon in deciding whether to permit, prohibit, or soniehow constram the inspections. The negotiators and impleinenters of an Open Skies agreement should therefore seek to mamipulate these five variables in advance: (a) the power of the collection niethodology; (b) the purposes of the search; (c) the character of the places to be searched; (d) the opportunities to iminimize the invasion of citizens' privacy; and (e) the availability of suitable recourse for abuse. Finally, the Article offers some concluding observations on the need to adapt both constitutional law and arms control programs in order to enbrace future challenges and opportunities.

\section{I}

\section{The Evolution of the Open Skies Concept}

The current version of the Open Skies concept is a lineal descendent of the 1955 proposal. This Part describes the earlier iteration of negotiations, the progress niade in 1989-1990, and some of the factors that com- 
bine to inake the present Open Skies idea even more relevant and potentially even more powerful than the original.

\section{A. Eisenhower's Original Suggestion}

During the 1950s, the United States and the Soviet Umion frequently exchanged disarmament proposals regarding a variety of security-related topics, but they managed to locate precious few areas of agreement. ${ }^{15}$ In 1955, a panel of White House experts headed by Nelson Rockefeller and Harold Stassen, then special assistants to the President, investigated the possibility of presenting sone type of novel proposal at the upcoming Geneva Conference of Heads of Government. ${ }^{16}$ Open Skies attracted support within the administration ${ }^{17}$ as a method of mitigating the dangers of surprise attack, ${ }^{18}$ testing Soviet willingness to accept the principle of imtrusive inspection, ${ }^{19}$ and securing real advantages for American

15. See Control and Reduction of Armaments: Hearing on S. Res. 93 Before the Subcomm. on Disarmament of the Senate Comm. on Foreign Relations, 84th Cong., 2d Sess. 10-15 (1956) [hereinafter Hearing] (statement of Harold E. Stassen, Special Assistant to the President for Disarmament, reviewing United States and Soviet negotiating postures); B. BECHHOEFER, POSTWAR NeGOTIATIONS FOR ARMS CONTROL 290-97 (1961) (discussing the comprehensive Soviet disarmament program of May 1955); G. MYrdal, THE GAME OF Disarmament 78-84 (1976) (asserting that both the United States and the Soviet Union were more interested in propaganda than in real disarmament during most of the 1950s); W. ROSTOW, OPEN SKIES: EISENHOWER'S Proposal of JULy 21, 1955, at 1114-19 (1982) (text of Soviet proposal); STANFORD ARMS Control Group, International ARMS Control: Issues and Agreements 94-102 (C. Blacker \& G. Duffy 2d ed. 1984) (describing Uinted States' "Baruch Plan" and "Atoms for Peace" proposals and the USSR's various responses).

16. See 2 S. AMBrose, EISENhOWER 258-59 (1984) (recounting the Eisenhower administration's preparation of the Open Skies proposal); BACKGROUNDER, supra note 10 (regarding the evolution of the Open Skies proposal generally); W. Rosrow, supra note 15, at 46-47 (recouuting how Rockefeller presented the idea to Eisenhower). The concept of aerial inspection to aid disarmament had been considered in 1946 and 1952, but the proposals had not progressed very far. See Hearing, supra note 15, at 36; Pounds, Proposals for On-Site Inspection Over the Years: From the Baruch Plan to the Reagan Initiatives, in ARMS CONTROL VerIfication \& THE NEw ROLE OF ON-STrE INSPECTION 69-91 (L. Dunn \& A. Gordon eds. 1990).

17. See Arms Control and Disarmament Div., External AfFairs and INT'l Trade CANADA, Open Skies: OpportunItY for the 1990s, BACKGRounder No. 2, at 2-3 (1990) [hereinafter BACKGROUNDER No. 2] (Open Skies was conceived by analysts working for Nelson Rockefeller, and although Secretary of State John Foster Dulles opposed the idea, Eisenhower came to see it as a dramatic proposal capable of capturing the public's inagination); W. RosTow, supra note 15, at 46-47 (Rockefeller's plan saw resistance at first, but eventually Eisenhower warmed to it).

18. During the 1950s, the fear of a surprise attack-a Soviet version of the Nazi blitzkrieg that had proven so effective a decade earher-drove American military strategists, and they devoted a great deal of planning and deployment to forestalling that possibility. See Rosenberg, The Origins of Overkill: Nuclear Weapons and American Strategy, 1945-60, in 7 INT'L SEcurrTy 3, 31-32, 38-40 (1983) (describing Eisenhower's preparations for defending against surprise nuclear attack). Open Skies reconnaissance seemed to promise a partial solution for that fear. See Hearing, supra note 15, at 22; Leghorn, Aerial Reconnaissance, in Selected Readings in Aerial Reconnaissance 6, 9 (A. Katz ed. 1963); Levison, Capabilities and Limitations of Aerial Inspection, in INSPECTION FOR DisarmamenT 59 (S. Melman ed. 1958).

19. W. Rostow, supra note 15, at 29-30; see also Hearing, supra note 15, at 22 (American officials described Open Skies as only the "gateway" or "threshold" to an overall disarmament plan). 
intelligence. $^{20}$

At the conference on July 21, 1955, Eisenhower described the gist of the Open Skies concept:

I should address myself for a moment principally to the delegates from the Soviet Umion, because our two great countries admittedly possess new and terrible weapons in quantities which do give rise in other parts of the world, or reciprocally, to the fears and dangers of surprise attack.

I propose, therefore, that we take a practical step, that we begin an arrangement, very quickly, as between ourselves-immediately. These steps would include:

To give to each other a complete blueprint of our military establishments, from beginning to end, from one end of our countries to the other; lay out the establishments and provide the blueprints to each other.

Next, to provide withm our countries facilities for aerial photography to the other country-we to provide you the facilities within our country, ample facilities for aerial reconnaissance, where you can make all the pictures you choose and take them to your own country to study; you to provide exactly the same facilities for us and we to make these examinations-and by this step to convince the world that we are providmg as between ourselves agamst the possibility of great surprise attack, thus lessening danger and relaxing tension. Likewise we will make more easily attainable a comprehensive and effective system of inspection and disarmament, because what I propose, I assure you, would be but a beginning. ${ }^{21}$

During this period, the Soviets favored an agreement to permit foreign inspectors to be stationed in ground control posts at key railyards, airports, and seaports to monitor military activities on the spot. Western proposals stressed instead the advantages of aerial photography. Levison, Air Inspection, in First STEPs To DISARMAMENT 100, 104-05 (E. Luard ed. 1965).

20. Reconnaissance satellites were not yet available, and the closed nature of Soviet society had meant that the United States did not have access to basic military data about the Soviet Union, such as the number of troops, aircraft, and ships. The corresponding information about American forces, meanwhile, was readily available to the Soviets through open sources. An Open Skies regime would have partially redressed this asymmetry, but the Soviets feared that it would also provide the United States with the targeting information necessary to plan a surprise first strike against them, at a time when the Soviet Union could neither defend itself against a massive long-range bomber assault nor credibly threaten to retaliate in kind. See A. KRASS, VERIFICATION: How MUCH Is ENOugh? 118 (1985) (U.S. Strategic Air Command needed better intelligence); Morrison, Opening the Skies, 1989 NAT'L J. 3020 (quoting Khrushchev's opirion that Open Skies was a means of gathering targeting information); A. Katz, Some Notes on the History of Aerial Reconnaissance, Part I (Apr. 1966) (unpublished manuscript available from the Rand Corporation) (surveying the military applications and utility of aerial recounaissance).

21. Levison, supra note 19, at 103-04; Statement on Disarmament by President Eisenhower to the Heads of Government Meeting in Geneva, Switzerland (July 21, 1955), reprinted in Meeting of Heads of Government at Geneva, 33 DEP'T ST. BuLL 171, 174 (1955). At the opening of the summit conference, Eisenhower stressed that the mutual fear of surprise attack was frustrating the superpowers' pursuit of the disarmament goals of the United Nations Charter, and that in seeking to reduce the possibility of such aggression, "nothing is more inportant than that we explore together the challenging and central problein of effective inutual inspection. Such a system is the foundation for real disarmament." Opening Statement by President Eisenhower to the Heads of Government 
Despite a chilly initial reception from the Soviets, ${ }^{22}$ the concept of Open Skies recurred in discussions at high levels. The United States circulated a more detailed version of the proposal on August 30, 1955, elaboratimg the mechamics of the anticipated exchange. ${ }^{23}$ Premier Bulganin, in a September 19, 1955 letter to President Eisenhower, voiced reservations about the scope of the proposal, ${ }^{24}$ but during 1956 the two sides appeared to be nearing agreement on a test run of the idea, which would have applied to only a limited sector of Europe. ${ }^{25}$ Although they also

Meeting in Geneva, Switzerland (July 18, 1955), reprinted in Meeting of Heads of Government at Geneva, supra, at 172.

22. See M. BunDy, supra note 9, at 295,301 (stating that the Geneva proposal "died the day it was born"--the Soviet language in response to Open Skies was formally polite, but never reflective of sincere interest). Former Soviet Ambassador Anatoly Dobrynin has suggested that Khrushchev, believing that the United States would be inore nonplussed by a Soviet acceptance of the proposal than by a predictable rejection, wanted to confound American expectations by responding positively. The Politburo rejected that strategy, however. Morrison, supra note 20, at 3020. Eisenhower himself concluded that, despite his own good faith, the Soviet leadership considered the Open Skies proposal "nothing inore than a bald espionage plot against the Soviet Union." 2 S. AMBRoSE, supra note 16, at 265; BACKGROUNDER No. 2, supra note 17, at 4 .

23. Statement by Henry Cabot Lodge, Jr. before a Subcomm. of the U.N. Disarmament Comm'n (Aug. 29, 1955), reprinted in Inspection as the Key to Disarmament, 33 DEP'T ST. BuLL. 438, 439-40 (1955). The United States submitted a detailed plan to the Disarmament Subcommittee of the United Nations Commission on Disarmament. The plan included both ground-based observers (which the Soviets appeared to prefer) and aerial inspection. Levison, supra note 19, at 104. American negotiators followed up on the proposal by submitting additional details to the Disarmament Subcommittee later in 1955. See Teltsch, U.S. Asks Priority for Aerial Check in U.N. Arms Talks, N.Y. Times, Dec. 3, 1955, at Al, col. 8; Statenent by Harold Stassen before a Subconn. of the U.N. Disarmament Comm'n (Oct. 7, 1955), reprinted in Disarmament and the President's Geneva Proposal, 33 DEP'T ST. BuLl. 703 (1955). However, there is also evidence that in late 1955, the United States hardened its position regarding Open Skies and, accordingly, consensusbuilding became inore problematic. See G.A. Res. 914, 10 U.N. GAOR Supp. (No. 19) at 5, U.N. Doc. A/3116 (1955) (urging the Disarmament Commission to pursue Eisenhower's proposals for Open Skies); B. BECHHOEFER, supra note 15, at 311 (stateinent of U.S. representative to U.N. Disarmament Conımission); G. MYRDAL, supra note 15, at $82-83$ (discussing lack of public support).

24. Letter from Nikolai A. Bulganin to President Eisenhower (1955), reprinted in President and Soviet Premier Exchange Views on Inspection, 33 DEP'T ST. Bull. 643 (Oct. 24, 1955); see also W. Rostow, supra note 15, at 64 ("the Bulganin letter did not rule out the possibility of mutual aerial inspection playing an ultimate role in arms control proposals, but it flatly rejected Eisenhower's fundamental proposition" that arms control ineasures could not succeed without Inutual confidence that verification was possible and reliable); Levison, supra note 19, at 104 (Bulganin stressed that actual reductions in arms, rather than merely the mechanisms for monitoring reductions, should be the primary objective of the negotiations; he also stressed that the anticipated provisions for exchange of blueprints and for aerial overflight should apply to all countries, not just to the superpowers). Secretary of State Dulles assured the Soviets that once the basic bilateral Open Skies program was in place, the United States would negotiate extending the program to other countries. Hearing, supra note 15, at 8 (describing Dulles' statements at Geneva in Nov. 1955).

25. In March 1956, Harold Stassen proposed a plan for reciprocal aerial inspection of an area of 20,000-30,000 square iniles in the United States and Soviet Union. On Noveniber 17, 1956, the Soviet Union counter-proposed aerial and ground-based inspection of a zone 1000 miles wide down the center of Europe. Levison, supra note 19, at 105. The negotiators almost achieved agreement in mid-1957 regarding a zone of inspection covering much of Europe, almost half of Siberia, and a portion of the continental United States. B. BECHHOEFER, supra note 15, at 343-49; Levison, supra 
considered various other candidate zones of inspection over the next two years, the two sides were never able to find sufficient common ground. ${ }^{26}$

By the end of 1958, the tenuous consensus on Open Skies had dissolved amid a host of other political and technical issues, ${ }^{27}$ and no agreement was ever implemented. ${ }^{28}$ In 1960, the downing of Gary Powers' U. 2 reconnaissance aircraft over the Soviet Union poisoned the atmosphere for further consideration of aerial surveillance, ${ }^{29}$ and arms control negotiators turned their attention to other opportunities. ${ }^{30}$ The idea of Open Skies was shelved as an interesting and pronrising suggestion that never went anywhere. ${ }^{31}$

note 19, at 106. In 1958, the Soviet Union vetoed a Security Council resolution that would have endorsed the concept of aerial inspection for nuch of the territory above the Arctic Circle. 2 U.S. DeP'T OF STATE, Documents on Disarmament, 1957-1959, at 1005 (1960).

26. The United States incorporated aerial reconnaissance into another proposal in May 1957, but when Britain, France, and West Germany objected to the inspection provisions, the United States withdrew the proposal from consideration. Levison, supra note 19, at 106. There were also suggestions that the United States or the United Nations should inplenient a unilateral program of Open Skies overflights even if the Soviet Union objected. The United States would build aircraft to penetrate Soviet airspace at high altitudes, and the inevitable occasional losses would siniply be part of the price of obtaining adequate intelligence about eneiny military activities. See Leghorn, supra note 18, at 9-10; Leghorn, How Aerial Inspection Would Work, U.S. NEWS \& WORLD REP., July 29, 1955, at 83. The United States did briefly use very high-altitude balloons to carry reconnaissance cameras over the Soviet Union, but these had limited utility since they were uncontrollable, not directed at specific targets but rather drifting with the winds. Blair \& Brewer, Verifying SALT Agreements, in Verification and SALT 7, 9 (W. Potter ed. 1980).

27. Negotiations in Geneva took place from November 10 to December 18, 1958, but the two sides reniained far apart regarding Open Skies. The Western delegates focused on the technical aspects of the inspection scheine, whereas the Eastern representatives first wanted to address the poitical underpinnings. The two sides never bridged their differences. Levison, supra note 19, at 106.

28. The United States Arms Control and Disarmainent Agency continued research into aerial and other inspection inethodologies, see 4 U.S. ARMS ConTrol AND DisARMament AGENCY, ANN. REP. 24-25 (1965), but the issue of Open Skies disappeared front the negotiators' agendas after 1958. See Levison, supra note 19, at 107.

29. See Cohen, The Evolution of Soviet Views on SALT Verification: Implications for the Future, in Verification and SALT, supra note 26, at 49, 56; Moser, The Time of the Angel: The $U-2, C u b a$, and the CIA, AM. HerITAGE, Oct. 1977, at 4. U-2 overflights of the Soviet Union, even when they were possible, could hardly be an adequate substitute for Open Skies. The spy planes did not have nearly the capacity for coverage of the Soviet Union that a treaty could have provided, and the limitations on the U-2 program were "almost shocking." W. RosTow, supra note 15, at 74 (quoting personal comnunication from Paul Worthman).

30. Limitations on the testing of nuclear weaponry came to the forefront at this time, and the Limited Test Ban Treaty, Aug. 5, 1963, 14 U.S.T. 1313, T.I.A.S. No. 5433, 480 U.N.T.S. 43, was concluded in 1963.

31. The Open Skies proposal at least temporarily served the function of seizing for the United States the moral and political initiative in the world's search for appcaling disarmannent ideas. It also helped establish Eisenhower as a leader in the efforts to achieve peace. See W. Rostow, supra note 15, at 57-58; cf. Baldwin, Arms Control: Can U.S. Plan Work?, N.Y. Tines, Sept. 18, 1955, at B6, col. 1 (although Open Skies nrarked a shift from an idealistic U.S. goal of elinninating nuclear weapons to a practical goal of inonitoring and preventing their use, the proposal convinced neutral nations that the U.S. supported peace efforts). By late 1960, the United States (and by 1962, the 


\section{B. Open Skies Revived}

For the next three decades, Eisenhower's proposal received httle active attention. ${ }^{32}$ Then, in Septeinber 1986, the Stockholm Document on Confidence- and Security-Building Measures in Europe ${ }^{33}$ announced East-West accord on a variety of steps to increase the "transparency" of each bloc's military apparatus. ${ }^{34}$ The Stockholm Document included four provisions establishing the principle of aerial reconnaissance as an easy and higli-confidence means of inonitoring questionable military activities througlout the continent. ${ }^{35}$

The real resurgence of Open Skies, however, came when President Bush invoked Eisenhower's ideas in a May 12, 1989, speeclı at Texas A\&M University, his first major address as President on U.S.-Soviet relations. ${ }^{36} \mathrm{He}$ called for reconsideration of Open Skies, "but on a broader, more intrusive and radical basis." 37 The NATO heads of government

Soviet Union) had developed reconnaissance satellites that partially fulfilled the original surveillance goals of Open Skies overflights. W. RosTow, supra note 15, at 10.

32. There were occasional suggestions that Open Skies might play a role in the verification of nodern arms control accords, but these were almost wistful in tone, regretting the lost opportunity of the 1950s to effectuate a helpful inspection process. Perry, The Forces of Verification: Strategic Arms Control for the 1980s, The Rand Paper SerIES, Aug. 1977, at 19-20. The concept of aerial inspection appeared from time to time; for example, provisions of the Antarctic Treaty declare that "[a]erial observation may be carried out at any time over any or all areas of Antarctica" in order to verify conpliance with the treaty's disarmament and other provisions. Antarctic Treaty, Dec. 1, 1959, art. VII, § 4, 12 U.S.T. 794, 797, 402 U.N.T.S. 71, 76.

33. Document of the Stockholm Conference on Confidence- and Security-Building Measures and Disarmament in Europe, reprinted in 1987 SIPRI Y.B. 365 [hereinafter Stockholm Document].

34. In the Stockholm Docunient, the 35 negotiating parties (including the United States and the Soviet Union) agreed to pursue a variety of mechanisms for airborne and terrestrial monitoring of nilitary facilities, equipment, and exercises. Although only partially implemented, the agreement nonetheless reflected the great increase in the various states' willingness to accept the principle of intrusive inspeetion for arms control purposes. BACKGROUNDER, supra note 10, at 2-3.

35. Provisions 89 through 92 of the Stockholn Document specify that personnel froin the inspecting state (1) may use airplanes or helicopters, (2) are entitled to a "continuons view of the ground during the inspection," (3) inay enter the inspection area "without delay," (4) inay use navigational maps and charts, and (5) may stay in the inspection area up to 48 hours. Stockholm Document, supra note 33, at 366; BACKGROUNDER, supra note 10, at 2-3.

36. See Krepon, With Lack of High-Up Interest, "Open Skies" Treaty Falls by Wayside, L.A. Times, Oct. 7, 1990, at M2, col. 1.

37. N.Y. Times, May 13, 1989, at A6, col. 1; Address by President George Bnsh, Texas A\&M Univ. Commencement Ceremony (May 12, 1990), reprinted in Bush, Clange in the Soviet Union, U.S. Dep't of State, Current Policy No. 1175, at 2. During the Summer of 1989, President Bnsh "decided to go forward with a policy of maximum openness and nuaximum flexibility, after the U.S. intelligence coinmunity conducted a net assessment of the benefits and risks." HENRY L. STIMSON CENTER, OPEN SKIEs 2 (1989) [hereinafter STIMSON CENTER] (general background presentation by a Bush admimistration official delivered at the Mnltilateral Verification Project). The inost complete publicly available works analyzing the history and current status of the Open Skies negotiations are L. DUNN \& B. HENRY, OPEN SKIES AND CFE AERIAL INSPECTION: REPORT OF A WORKSHOP Sponsored by the arms Control Program of Los Alamos National labratory (Aug. 30, 1990) (published by Science Applications Int'l Corp.); B. HeNRY \& R. DAvis, OPEN SKIES AND CFE Aerial INSPECtion: Background PAPER for Workshop on Open SKies and Aerial 
endorsed the principle in a communiqué issued froin Brussels on May 30, $1989,{ }^{38}$ and propounded an elaborate set of "Basic Eleinents," outlining inany of the details, on Deceniber 15, 1989.39

This time, the Soviets' initial response was supportive. ${ }^{40}$ At their meeting in Wyoming on September 22 and 23, 1989, Secretary of State James A. Baker III and Soviet Foreign Minister Eduard Shevardnadze "agreed in principle" to the concept of Open Skies, which they said "could make a genuine contribution to openness and confidence-buildmg." 41 They also expressed their willingness to attend an international conference on the subject. ${ }^{42}$

The first round of that international conference, which initially imvolved the foreign ministers of the participating nations, took place in Ottawa, Canada, on February 12 through $28,1990 .{ }^{43}$ Although partially overshadowed by discussion of Gerinan reunification and conventional force reductions in Europe, Open Skies was agam a "hot" topic, ${ }^{44}$ with several states offering additional wrinkles on the concept, and with little if any iniportant dissent. Secretary Baker declared that Open Skies was "potentially the inost important measure to build confidence ever undertaken" by NATO and the Warsaw Pact. ${ }^{45}$ Representatives of the two blocs sought to outdo each other in floating increasingly far-reaching proposals. ${ }^{46}$

INSPECTION (May 31, 1990) (published by Science Applications Int'l Corp.); Hawes, Open Skies: From Idea to Negotiation, NATO ReviEw, Apr. 1990, at 6; Tucker, Back to the Future: The Open Skies Talks, 20 Arms Control Today, Oct. 1990, at 20; see also Krepon, Conditions Ripe to Puncture Aerial Borders, Defense News, Oct. 30, 1989, at 27, col. 1 (noting the parallels in formulation, strategy, and diplomacy between Eisenhower's proposal in 1955 and Bush's in 1989).

38. See BACKGROUNDER, supra note 10, at 1, 3; Tueker, supra note 37, at 21-22.

39. NATO Press Service, Open Skies: Basic Elements Agreed by the North Atlantic Council Mecting in Ministerial Session at NATO Headquarters, Brussels (Dec. 15, 1989).

40. There were, however, some Americans (both inside and outside the Bush administration) who were at least initially unreceptive to the idea of reviving Eisenhower's proposal. See Grossman, Keep the Eyes in the Skies, Christian Science Monitor, June 30, 1989, at 19, col. 1 ("It would be difficult to think of any proposal less relevant."); Krepon, supra note 37, at 27, col. 1 ("most observers dismissed the idea as a public relations stunt"). The idea was described as a "top down" rather than a "bottom up" proposal, indicating that it originated with senior White House advisors rather than percolating up through the burcaucracy. Sinith, Bush Plan Predates Satellite, Wash. Post, May 13, 1989, at A14, col. 1.

41. Joint Statement on Arms Control by James A. Baker III and Eduard Shevardnadze, Jackson Hole, Wyo. (Sept. 23, 1989), reprinted in 19 ARMS CONTROL TODAY, Oct. 1989, at 22.

42. Id.

43. Lewis, U.S. Presents Plan for German Unity, N.Y. Times, Feb. 13, 1990, at A10, col. 1.

44. Lewis, Accord in Ottawa, N.Y. Times, Feb. 14, 1990, at A1, col. 6.; Open Skies Conference Communiqué (Feb. 13, 1990), reprinted by U.S. Arms Control and Development Agency [hereinafter "Open Skies Communiqué"]. While issues surrounding German unification dominated the headlines, work on Open Skies continued at the conference, and the three days of ministerial meetings were followed by an additional ten days of deliberations at the technical level, to concentrate more fully on Open Skies. Lewis, supra, at A10, col. 4.

45. Lewis, supra note 43 , at A10, col. 1 .

46. See, e.g., Opening Statement by Sergiu Celac, Minister of Foreign Affairs, Romania, Open 
The second round of the conference was held in Budapest, Hungary, from April 23 through May 10, 1990. This session was disappointing, registering less progress than treaty adherents had anticipated, and the negotiators have not yet scheduled a third round of talks. ${ }^{47}$ Nonetheless, the general perception remains that ouly a relatively small number of important issues now separate the negotiators, and that if the leading states demonstrate sufficient political will, a treaty could be ready for signature in the near future. ${ }^{48}$

In the imterim, soine countries have already undertaken partial measures of implementation. Canada and Hungary, for example, experimented with a trial Open Skies overflight on January 4 througli 7, 1990. The trial was designed to test flight planning and safety procedures and to investigate the arrangements necessary to ensure smooth reciprocal monitoring. ${ }^{49}$ Reportedly, the mock inspection was "quite

Skies Conference, Ottawa (Feb. 12, 1990); Opening Statement by Gyula Horn, Minister of Foreign Affairs, Hungary, Open Skies Conference, Ottawa (Feb. 12, 1990); Statement by Jiri Dienstbier, Minister of Foreign Affairs, Czechoslovakia, Open Skies Conference, Ottawa (Feb. 12, 1990) (all expressing support for Open Skies). The government of Canada has been particularly active in promoting the concept of Open Skies. See, eg., BACKGRounder No. 2, supra note 17, at 6-7 (Canada supports Open Skies because it will provide smaller nations with the technological means to mointor areas of concern, will distribute the burden of momitoring among the North Ameriean and European allies, and will represent a practical step in improving East-West relations).

47. See Krepon, supra note 36, at M2, col. 1. During their June 1990 summit mecting, Bush and Gorbachev spent more time on Open Skies than on any other arms control topic except START. Id.; see also 9 Arms Control Rep. (IDDS) 409.B.18 (Dec. 1990) (Canada proposes third round of negotiations); N.Y. Times, June 4, 1990, at A14, col. 1 (Following the summit, Bush was "hopeful that the good discussion between President Gorbachev and-the one we had about the importance of 'open skies'-will revive those negotiations."); 10 Arms Control Rep. (IDDS) 409.B.21 (Feb. 1991) (NATO is developing a package of new Open Skies negotiating positions designed to ehicit a favorable response from the Soviet Union)

48. See Tucker, supra note 37, at 24 (suggesting that a treaty could be reached in one more round of negotiations, if the U.S. and Soviet Umion are ready to compromise); Leopold, U.S. Begins Efforts to Revive Open Skies Talks With Soviet Union, Defense News, Dec. 10, 1990, at 27, col. 1 (U.S. will launch high-level effort to revive talks over next several months); Krepon, supra note 36, at M2, col. 1 (Bush administration has concentrated on other arms control imitiatives, and has not invested sufficient energy in Open Skies negotiations to overcome Soviet resistance); Lewis, supra note 44, at A10, col. 6 (negotiators concluded first round of talks with a broad agreement that an Open Skies accord was desirable, and hoped to complete such an accord during the second round of talks).

49. Adams \& Lowman, Canadian Flight Over Hungary Marks Trial Run of U.S. Open Skies Intiative, Defense News, Jan. 15, 1990, at 25, col. 1; Canadian Gov't Press Release, Canada and Hungary Conduct a Trial "Open Skies" Overflight (Jan. 1990). In the mock overflight, a Canadian C-130 Hercules military airplane traversed Hungary for three hours at a variety of altitudes, sinulating the flight plan an Open Skies aircraft might wish to follow. The exercise included overflying a Soviet military base. Hungarian officials inspected the plane before and after the flight and had observers inside the plane at all times. The observers had full access to all areas of the aircraft and continuously momitored its perfornance. In contrast to an actual Open Skies overflight, this experiment included no photographic or other sensors; it thus tested only the flight procedures. Canada has invited Hungary and the Soviet Union to undertake a corresponding overflight of Canadian airspace. Adams \& Lowman, supra, at 25, col. 1; Canadian Gov't Press Release, supra, at 3. 
satisfactory." 50

In addition, the basic concept behind Open Skies-reliance upon aerial overflight and observation to promote military transparency and mutual confidence-has also been incorporated into the new Treaty on Conventional Forces im Europe (CFE Treaty). ${ }^{51}$ That inultilateral accord obligates parties to accept "an agreed number of aerial inspections"52 and contemplates ongoing negotiations to develop acceptable quotas "and otlier applicable provisions."53 The relationship between the Open Skies talks and the CFE Treaty process has traditionally been a close one and the issues involved have substantially overlapped. ${ }^{54}$ Although the two regimes are similar in concept--botll rely on international overliead reconnaissance-there are important differences in their respective goals, ${ }^{55}$ equipment, ${ }^{56}$ and geographic coverage, ${ }^{57}$ and the two negotiations continue to proceed independently.

\section{Open Skies Technology}

In the thirty-five years since Eisenhower announced his initial vision of Open Skies, stunning technological advances have vastly expanded the potential power and intrusiveness of aerial reconnaissance. Open Skies today would permit observation of unprecedented intensity, revealing

50. Adams \& Lowman, supra note 49, at 25, col. 1 (quoting Edward Rowny, Special Assistant for Arms Control to the Secretary of State). But see 9 Arms Control Rep. (IDDS) 409.B.7 (Mar. 1990) (noting "problems showing up in the test flight over Hungary").

51. CFE Treaty, supra note 7.

52. Id. art. XIV, If 6.

53. Id. Those impleinenting talks, dubbed "CFE 1A," began in Noveinber 1990, but there is no agreed timetable for their completion.

54. Originally, the negotiating parties contemplated that the Open Skies negotiations would progress more rapidly, elaborating the details of an aerial inspection program that could then be adapted for CFE Treaty purposes. However, when the Open Skies talks stalled in Spring 1990 and the CFE talks bolted ahead, many expected that the contemplated relationship would then reverse, with Open Skies eventually building upon the CFE Treaty's evolving model. See L. DuNN \& B. HENRY, supra note 37, at 15-17; B. HENRY \& R. DAVIS, supra note 37, at 15-16; Hitchens, NATO Pegs Sensors to Verify Treaties, Defense News, Sept. 24, 1990, at 18, col. 1. Eventually, the CFE Treaty was drafted with only a general commitınent to aerial inspection, deferring negotiation of the details to subsequent talks. Questions of overflight, equipment, and use of data therefore reinain active in both fora.

55. The CFE Treaty relies upon aerial inspection as a supplemental tool of verification to monitor comphance with provisions that limit the deployment of specified armainents, while Open Skies is considered more of a confidence-building measure, independent of any specific program of weapons reductions.

56. The CFE and Open Skies negotiations may lead to somewhat different outcomes on such critical unresolved issues as the types of aircraft and sensors and the use of aequired data. See infra notes 112-17 and accompanying text.

57. The most important distinction between Open Skies and the CFE Treaty concerns geographic scope. The CFE Treaty is applicable to the continent of Europe "from the Atlantic Ocean to the Ural Mountains." B. HENRY \& R. DAvis, supra note 37, at 16. Open Skies, on the other hand, would also permit overflight of the United States, Canada, and the Asian portions of the Soviet Union. 
many more details of military activity than have previously been available. ${ }^{58}$ The technology used to render military structures "transparent," however, would inevitably also expose intimate aspects of nonmilitary, nongovernmental private life protected by the Constitution.

Reciprocity is an indispensable aspect of any arms control arrangement, and under an Open Skies regime, eacli nation would serve as both imspector and lost. ${ }^{59}$ Thus, foreign monitors would be legally empowered to overfly the entirety of the United States, with hittle if any advance notification to the intended targets of scrutiny. Military installations and other government facilities would certainly be of the greatest interest, ${ }^{60}$ but private businesses and individual dwellings would also be subject to unrestricted and unarmounced observation. ${ }^{61}$ The vast size of the United States would ensure that, as a practical matter, no particular location would encounter very frequent overfliglits. Nonetlieless, nothing in the treaty would prevent repeated observation, either througlı direct overflight or through the use of "slant photography," whiclu allows aircraft to inomitor targets located many miles to the side. ${ }^{62}$

Open Skies observation will be umque not ouly in the frequency of overflights, but also in the sophistication of the nomitoring technology.

58. See Spitzer, Aerial Observation and Overfights, in Verification of Conventional ARMS IN EUROPE: TeChNological ConstrainTS AND OpPoRtunities 89-122 (R. Kokoski \& S. Koulik eds. 1990).

59. The traditional dynamic of modern arms control negotiations has usually involved the United States pressing for, and the Soviet Union resisting, intrusive measures of inspection to verify compliance with the terms of any agreement. Most observers, including many Soviets, came to think in terms of the United States principally advocating the interests of the "inspecting state" and the Soviet Union mainly championing the concerns of the "host state." See Stovall, A Participant's View of On-Site Inspections, Parameters, June 1989, at 2 ("[T] he Soviets are inost concerned with foreign intrusion while the U.S. is most concerned with comphiance verification."). But see Krass, The Soviet View of Verification, in Verification AND ARMs Control 37-38 (W. Potter ed. 1985) (Soviet leaders' actions have always refleeted their concern for verification of compliance). Of course, any inspection rights imcorporated imto a disarmament treaty would have to be fully reciprocal as between the two superpowers, and in recent years, the tables have turned somewhat, with the Soviet Umion now sometimes calling for intrusive inspection powers and the Urited States expressing wariness that the verification process might compromise legitimate privacy interests.

60. Foreign arms control inspectors under an Open Skies treaty would be seeking principally evidence of military activities, and would focus their primary attention on such installations as military bases, government laboratories, and military production facilities. But private factories or warehouses suspected of producing or storing weapons would also be momitored, as would almost any industrial facility that could be adapted for producing weapons clandestinely. Indeed, the mobility and small size of many modern weapons suggests that almost any place could be converted into a covert storage depot and thereby be an appropriate subjeet of Open Skies monitoring.

61. Regardless of which targets they sought to monitor, foreign inspectors would inevitably overfly and collect information from private property located near their intended targets. As discussed below, see infra Part IV, this practice would raise issues of the conversion of trade secrets, the invasion of privacy, and the deteetion of contraband.

62. Blair \& Brewer, supra note 26, at 34. The side-looking radar of the United States' SR71 reconnaissance aircraft has a peripheral vision of up to 80 miles. Sloyan, Spies in the Sky, Wash. Post, Feb. 25, 1990, at B1, col. 1, B4, col. 1. 
The types of sensors, their degree of sensitivity, and the details of the resulting imagery would be unprecedented. ${ }^{63}$ Regarding "ordinary" photography, for example, although nations closely guard the exact capabilities of their current photoreconnaissance satellites, publicly discussed estimates suggest a resolution capability under optimal conditions of as fine as a few inches. ${ }^{64}$ Photography froin aircraft would have even better resolution and could regularly reveal iteins only a few square inches in size, and maybe smaller. ${ }^{65}$

In addition to relatively familiar types of visible-hight photography, Open Skies overflights could employ a host of esoteric technologies. For example, sophisticated non-optical systens could collect images at night or through some cloud cover. ${ }^{66}$ Infrared sensors could reveal phenomena invisible to the human eye, such as the difference between live and cut vegetation, perhaps indicating the presence of camouflage. Thermal sensors conld reveal heat gradients, which can suggest activity occurring underneath opaque roofs. ${ }^{67}$ Modern airborne radars can also be extremely revealing, even $\mathrm{m}$ adverse weather, ${ }^{68}$ in some cases even being capable of penetrating thin wooden roofs. ${ }^{69}$ Advanced coinputerized sys-

63. The SR71 "Blackbird," recently grounded by Air Force budget constraints, was the most advanced American reconnaissance aircraft. It is capable of fiying at four times the speed of sound and at altitudes im excess of 100,000 feet. Sloyan, supra note 62, at B4, cols. 1 \& 3 . Under optimal conditions, it could "pick out the numbers on a license plate or street sign." Id. at col. 1. Imagery from this aircraft lielped locate American prisoners of war in Vietnam, support the attempted rescue of the American hostages in Iran, and identify Moammar Qaddafi's personal tent prior to the 1986 American air strike against Libya. Richelson, Technical Collection and Arms Control, in VERIFICATION AND ARMS CONTROL, supra note 59, at 169, 177-78; Sloyan, supra note 62, at B4, col. 4.

64. D. Barash, The ARms Race AND Nuclear WAR 245 (1989) (reporting that "ground resolution on the order of $10 \mathrm{~cm}$ is regularly achieved" by photoreconnaissance satellites); Blair \& Brewer, supra note 26, at 19 (satellite plotoreconnaissance resolution is now on the order of three or four inclies, which is probably the best attainable, given the light-scattering effects of the atmospliere). See generally A. KRASS, supra note 20, at 16-28 (describing the development and procedure of satellite plotography); Spitzer, supra note 58, at 89-118 (discussing the capabilities of numerous forms of aerial reconnaissance teehnology).

65. The MITRE CORP., OPEN SKies AIRcraft: A Review of Sensor Suite CONSIDERATIONS 6 (Jan. 1990) [heremafter OPEN SKIES AIRCRAFT]. The observers could also use otlier sensors to acquire large-scale nnages. For example, the SR71 in one hour could film panoramas of 100,000 square miles. Sloyan, supra note 62 , at B4, col. 1 .

66. See generally J. Richelson, The U.S. INTElligence COMMUNITY 107-38 (1989) (describing modern remote imaging systems and capabilities).

67. See generally A. KRAss, supra note 20, at 30-32 (describing capabilities and limitations of thermal infrared sensing). Existing cquipinent can detect temperature variances as small as one-half degree Fahrenheit, indicating phenomena sucli as heated buildings or engines that have operated recently. STIMSON CENTER, supra note 37, at 3.

68. InTERA TECH. LTD., AirboRne Remote Sensing for Multi-Lateral Verification 2 (Nov. 1989) (paper presented to the Multi-Lateral Verification Project of the Henry L. Stimson Center).

69. OPEN SKIES AIRCRAFT, supra note 65, at 6 ("Synthetic Aperture Radars can be used to operate day or night, with or witlout cloud cover, and in fact can penetrate thin foliage or even thin wooden roofs."). 
tems can dramatically enhance imagery or compare current information with data acquired on previous passes, enabling observers to obtain still more detailed and accurate information about the target. ${ }^{70}$ Particulate samplers could collect dust or other debris that might indicate the occurrence and nature of events such as clandestine nuclear tests. ${ }^{71}$

If the contemplated Open Skies agreement or a subsequent elaboration of $i^{72}$ permitted the use of other types of equipment, collectively known as "signals intelligence" or "SIGINT," even more hitherto private activities would be precipitously revealed. ${ }^{73}$ Modern eavesdropping equipment can intercept telephone, telegraph, and fax transmissions. If Open Skies inspectors chose to focus their most sophisticated equipment on a particular target, they could detect and decipher the noise or vibrations from a typewriter or computer, see and read documents from afar, and monitor ordinary conversations-imcluding those occurring inside a closed office or home. ${ }^{74}$

Of course, the superpowers today already collect much of this type of intelligence, utilizing an impressive array of sensors designed to momtor one another's activities. ${ }^{75}$ These include the "national technical

70. A. KRASS, supra note 20, at 49-59 (technical discussion of image enhancement and image restoration); ADAM, Peacekeeping by Technical Means, IEEE SPECTRUM, July 1986, at 42, $52-53$ (describimg image-processing techniques to restore and enhance aerial photographs); Blair \& Brewer, supra note 26, at 25 (discussing use of false-color photography to reveal camouflaged objects); Hafemeister, Advances in Verification Technology, 41 Bull. ATOM. SCIENTISTS, Jan. 1985, at 35 (discussing contrast enhancement and filtering techniques); Richelson, supra note 63, at $206 \mathrm{n} .15$ (technical discussion of image enhancement and image restoration).

71. Richelson, supra note 63, at 197 (discussing aerial sampling and detection of nuclear explosions); see also OPEN SkIES AIRCRAFT, supra note 65, at 13 (Open Skies applications also mclude detection of cheimical weapon manufacturing); id. at 14, 17 (describing Open Skies applications to arms control verification through "acoustic momitoring" and "electronic tagging," two advanced technologies that could detect military equipment and operations).

72. Even without a signed Open Skies agreeınent, some have proposed extending its principles to other, even more ambitious arrangements, such as the cooperative operation of sensitive recormaissance satellites. See Danson, Sharing Information Is the Next Step, Globe and Mail, Jan. 23, 1990, at 7, col. 1 (suggesting that an Open Skies follow-up accord could include cooperative satellite reconnaissance).

73. J. RICHELSON, supra note 66 , at $167-80$ (discussing idea of collecting signals froun airborne "platforms"). See generally Richelson, supra note 63, at 178-86 (describing a variety of signals intelligence teclinologies); Lardner, National Security Agency: Turning On and Tuning In, Wash. Post, Mar. 18, 1990, at Al, col. 3 (illustrating the use of signals intelligence technology to track arms-for-hostage deals betwecn the U.S. and Iran).

74. See Marx, The New Surveillance, TECH. REv., May/June 1985, at 45, 47-48 (overview of modern surveillance teclinologies); Lardner, supra note 73, at A24, col. 1 (notes possibility of recording indoor conversations from the vibration of voices on window glass). But see OPEN SKIES AIRCRAFT, supra note 65, at 12 (suggesting that an Open Skies regime would not be especially useful for performing a SIGINT function, because effective interception of useful communications requires the ability to colleet data over a continuous period of time).

75. See generally W. ROWELl, ARMS CONTROL VERIFICATION $41-72$ (1986) (surveying various techmical and cooperative mechanisms for monitoring compliance with arms control agreements); R. Scribner, T. Ralston \& W. Metz, The Verification Challenge 47-66 (1985) (discussing technical means for arms control verification); Schear, Cooperative Measures of 
means of verification" or "NTM" (such as photoreconnaissance satelhtes, long-range seismometers, and radar facilities) enshrined in existing arms control treaties, ${ }^{76}$ as well as a variety of overt and covert human sources. ${ }^{77}$ Each of these observation tools makes a contribution, but each also has its limitations, and Open Skies overflights could add substantially to a nation's knowledge about its potential adversaries. ${ }^{78}$

\footnotetext{
Verification, in VERIFICATION AND ARMS CONTROL, supra note 59 (discussing cooperative ineasures of verification).

76. See Richelson, supra note 63, at 169 . Several earher arms control agreements have included nearly the same language to regulate the use of NTM. See Interim Agreement on the Limitation of Strategic Offensive Arms, May 26, 1972, United States-USSR, art. V, 23 U.S.T. 3462, 3465, T.I.A.S. No. 7504, at 4; Treaty on the Limitation of Anti-Ballistic Missile Systems, May 26, 1972, Umited States-USSR, art. XII, 23 U.S.T. 3435, 3443-44, T.I.A.S. No. 7503, at 9-10; Treaty on the Limitation of Strategic Offensive Arms, June 18, 1979, Umited States-USSR, art. XV, S. Exec. Rep. No. 14, 96th Cong., 1st Sess. 319, 421 (1979), 18 I.L.M. 1138, 1155-56, reprinted in ACDA TREATY BOoK, supra note 2, at 267, 288 (did not enter into force) [hereinafter SALT II Treaty]. These provisions generally permit the use of NTM "in a manner consistent with generally recognized principles of international law," prohibit "interference" with NTM, and ban "deliberate concealment ineasures" that impede verification by NTM.

The United States and the Soviet Union have never jointly defined the NTM protected by these treaties, but the United States has declared that NTM include photographic reconnaissance satellites, similar aircraft-based systems, and ground-based and sea-based systems such as radars. W. RoweLL, supra note 75, at 51-52; Cohen, The Evolution of Soviet Views on SALT Verification, in VERIFICATION AND SALT, supra note 26, at 55.
}

77. Diplomats and tourists, as well as spies, can provide data useful to the verification of compliance with arms control treaties, but all these human sources have become somewhat less important in the nodern era when the technical neans of nonitoring have proven so successful. See J. RICHELSON, supra note 66, at 233-49 (increased capability of collecting intelligence by technical ineans has reduced reliance on hunran sources, though the latter rentain useful for filling in gaps in intelligence); Moser, supra note 29, at 4, 6-7 (discussing the rise of sophisticated technology in the early 1950s and President Eisenhower's desire to decrease reliance on human resources).

78. See generally Hafeneister, Romm \& Tsipis, The Verification of Compliance With ArmsControl Agreements, 252 Scr. AM., Mar. 1985, at 39 (describing a number of high-technology surveillance methods and their limitations); see also OPEN SKIES AIRCRAFT, supra note 65, at 4 (advantages of aircraft for data collection). Several recent arms control treaties have recognized the importance of having inultiple sources for information about the weaponry to be regulated. These trcaties include provisions requiring an ongoing bilateral exchange of data that specifies the number of weapons in each of several relevant categories. See SALT II Treaty, supra note 76, Memorandum of Understanding Regarding the Establishnent of a Data Base on the Numbers of Strategic Offensive Arms, S. Exec. Rep. No. 14, 96th Cong., 1st Sess. 319, 440-44, 18 I.L.M. 1138, 1161, reprinted in ACDA TREATY BooK, supra note 2, at 267, 295; Treaty on the Elimination of Internediate-Range and Shorter-Range Missiles, Dec. 8, 1987, United States-USSR, S. Exec. Rep. No. 100-15, 100th Cong., 2d Sess. 1 (1988), 27 I.L.M. 90 [hereinafter INF Treaty], Memorandum of Understanding Regarding the Establishnient of a Data Base for the Treaty, 27 I.L.M. 90, 98, reprinted in ACDA TREATY BOoK, supra note 2, at 350,363. Some treaties have supplemented these provisions with agreements about the conduct of on-site inspection. See INF Treaty, supra, Protocol Regarding Inspections, 27 I.L.M. 90, 190, reprinted in ACDA TREATY Book, supra note 2, at 350, 431; Treaty on Underground Nuclear Explosions for Peaceful Purposes, May 28, 1976, United States-USSR (signed but not ratified) [hereinafter PNE Treaty], Protocol, S. Exec. Doc. N, 94th Cong., 2d Sess. 5, 9 (1976), 15 I.L.M. 891, 893, reprinted in ACDA TREATY BOOK, supra note 2, at 194, 198.

It should also be noted that coninercial airlines operated by European governments or private enterprises now routinely fiy over the territory of NATO and Warsaw Pact states. These civilian 
Satellites, for example, have assumed the greatest importance for arms control verification, ${ }^{79}$ but they' operate within severe constraints. Aircraft reconnaissance under an Open Skies agreement could therefore provide nations with a flexible means of supplementing the information they now gather, circumventing four major limitations of current satellite verification.

First, modern satellites are extremely expensive. Because of this, only the wealthiest nations use them, and even the superpowers can afford fewer than they would like. ${ }^{80}$ By contrast, aircraft are relatively inexpensive and are available to all states. ${ }^{81}$ Furthermore, the sensor

flights could be utilized for covert photography or other national intelligence purposes, achieving soine of the same effects as an effective inultilateral Open Skies agreement. There is, however, a stark asymmetry in these overflights: Soviet airliners regularly fly over virtually all of Western Europe, but contmercial aircraft front NATO states rarely fly over the portions of the Soviet Union east of the Ural Mountains. Even in European Russia, foreign overflights are much less common. An Open Skies treaty could redress this inbalance. Florini, Come Spy the Friendly Skies, 46 BuLL. ATOM. SCIENTISTS, Mar. 1990, at 13.

79. W. RowELL, supra note 75, at 44-47; Richelson, supra note 63, at 173-78.

80. StIMSON CENTER, supra note 37, at 1; Richelson, supra note 63, at 199. One expert has estinated that modern recounaissance satellites cost approximately $\$ 1$ billion each. Sloyan, supra note 62, at B4, col. 5. But cf. De Santis, Commercial Observation Satellites and Their Military Implications: Speculative Assessment, 12 WASH. Q., Summer 1989, at 185 (recounaissance satellites operated by several states or by conmercial enterprises will becone nore common in the future); Broad, Non-Superpowers Are Developing Their Own Spy Satellite Systems, N.Y. Tunes, Sept. 3, 1989, at 1, col. 1 (Britain, Spain, France, Italy, Israel, and perhaps other countries are developing electronic and photographic spy satellites).

Some have proposed establishing an International Satellite Monitoring Agency, through which nations could collaborate to share the expenses of building and operating reconnaissance satellites for arms control purposes. The U.N. General Assembly endorsed the concept in 1982, and it has been reiterated frequently, but it is still far from operational. 8 Arms Control Rep. (IDDS) If 850211 (Jan. 1989); Turner, Opening the World's Skies for Mankind, 1 SPACE PoL'y 357, 359 (1985); see also Jasani, Prins \& Rees, Share Satellite Surveillance, 46 BuLl. ATOM. SCIENTISTS, Mar. 1990, at 15 (discussing the pros and cons of a shared system of satellite surveillance). Similarly, some commercial satellite reconnaissance systenis offer imagery to the public, but these are generally incapable of producing resolutions as great as those of the superpowers' advanced military systems. Krepon, Peacemakers or Rent-a-Spies?, 45 Bull. Atom. Scientists, Sept. 1989, at 12-13. For related articles on this subject, sec Kennedy \& Marshall, $A$ Peek at the French Missile Complex, 45 BULL. ATOM. SCIENTISTS, Sept. 1989, at 20; Richelson, Military Intelligence-SPOT Is Not Enough, 45 Bull. Atom. Scientists, Sept. 1989, at 26; Spector, Keep the Skies Open, 45 Bull. Atom. ScientisTs, Sept. 1989, at 15; Zimmerman, Evidence of Spying, 45 Bull. ATOM. ScientisTs, Sept. 1989, at 24; Zimmennan, Photos From Space: Why Restrictions Won't Work, TECH. REV., May/ June 1988, at 47 [hereinafter Zimmerman, Photos From Space].

81. BACKGROUNDER, supra note 10, at 1, 7-8; INT'L INST. FOR STRATEgic STUdies, THE MiLITARY BALANCE 1989-90 (1989) (describing the reconnaissance aircraft many states operate today). An airborne inspection capability costs only about one-twentieth as much as a comparable satellite systen. BACKGROUNDER, supra note 10, at 8 . Of course, aircraft can be very expensive too: the American fleet of SR71 recounaissance planes, for exaunple, carried annual operating expenses of $\$ 200$ inillion. Sloyan, supra note 62, at B4, col. 5. But the Open Skies aircraft would not require nany of the high-performance (and high-cost) characteristics necessary for the SR71 to operate inside a hostile environment. See Gulfstream Aerospace, THE C-20F GuLfSTREAM: AN IDEAL PLATFORM FOR OPEN SKIES (undated advertising brochure for conntercial aircraft decmed suitable for Open Skies missions); supra note 63 (describing the SR71). 
technology required for remote aerial photography is not especially complex or costly, and suitable equipment could be readily accessible to all. ${ }^{82}$

Second, satellites are predictable. It is relatively easy to calculate the future trajectory of a monitoring satellite, smce most have very little ability to maneuver on demand. Even the most sophisticated American reconnaissance satellites, such as the recently launched Advanced $\mathrm{KH}$ 11, can take days to shift position im space in response to fast-breaking events. ${ }^{83}$ This predictability gives target nations an easy opportunity to halt or conceal earthborne activities prior to satellite overflight. ${ }^{84}$ Aircraft, however, provide a more flexible response, since they can be dispatched to any location at any time, can follow innumerable llight plans, and can "loiter," make repeat passes, or suddenly deviate from a given course. ${ }^{85}$ Aircraft can also be quickly adapted to specialized purposes, and can be outfitted with whatever sensors the particular occasion requires. ${ }^{86}$

82. A nation could accomplish Open Skies observation using inexpensive apparatus with sensors that do not embody the highest levels of technology. This type of photographic equipment is already commercially available, Nordwall, Kodak Team Develops Aerial Camera with Electro-Optic, Film Capability, Aviation WeEx \& SPACE TeCH., Aug. 15, 1988, at 101, and many states arc now pursuing this type of capability. See Countries Adopt Airborne Cameras As Altemative to Satellite Systems; Aviation WeEx \& Space Tech., Sept. 7, 1987, at 111. Because the systems arc not extremely sophisticated, U.S. laws restricting the export and transfer of sensitive equipment would impose few impediments. Morrison, supra note 20, at 3020; Notes from Canadian Open Skies Press Conference 2 (Feb. 8, 1990) (comments by Ambassador Bumey).

American defense officials have indicated that the United States would probably not use its most sophisticated sensors on an Open Skies mission; strategically, it would be wiser to use only second-best equipment im an operation where Soviet inspectors could learn so much about the equipment. The United States would reserve its top-of-the-lime hardware for more confidential purposes. DOD Will Alert U.S.-Based Forces Before Open Skies Overflights, Aerospace Daily, Jan. 19, 1990, at 107 [hereinafter Open Skies Overflights].

83. Sloyan, supra note 62 , at B4, col. 5 .

84. Reports suggest that both the United States and the Soviet Union regularly track the overflights of each other's reconnaissance satellites, so that they can delay, move, or conceal their most sensitive programs in order to conduct them without observation. Richelson, supra note 63, at 201.

85. An Open Skies agreeinent would require an inspecting aircraft to adhere to its previously filed fight plan (out of safety considerations, if nothing else), and it could not suddenly depart from the pre-announced and approved pattern. The advance notifieation process would provide time for the inspected state to secrete its most sensitive equipment and activities-an opportunity that American officials have already indicated the United States would not hesitate to exploit. Open Skies Overflights, supra note 82 , at 107 . Nonetheless, even if the overflymg aircraft cannot loiter Imannounced above a target or make surprise repeat passes, the operator can turn onboard sensors to acquire information from different angles as the plane passes over a fixed target. The aircraft can also simultaneously scrntinize a target with a number of different types of sensors and keep it under constant surveillance from "standoff" range. OPEN SKIES AIRCRAFT, supra note 65, at 1, 4.

86. See BACKGROUNDER, supra note 10, at 7 (airborne reconnaissance more technically flexible than spaceborne systems); Sloyan, supra note 62, at B4, cols. 1 \& 5 (aircraft are more technically flexible than satellites, quickly adaptable for a variety of missions). It is particularly noteworthy in this context that half the 42,000 locations in the "target base" for American photoreconnaissance are located outside the Soviet Union, Eastern Europe, and China, in areas that may not be covered well by satellites. Richelson, From CORONA to LACROSSE: $A$ Short History of 
Third, satellites are fragile. The Challenger shuttle disaster and resulting delays illustrate how inuch we still have to learn about safe space flight. ${ }^{87}$ Furthermore, the Strategic Defense Initiative and related anti-satellite weapons programs illustrate the potential vulnerability of satellites to systenus that can damage or destroy inanmade objects in space. ${ }^{88}$ Conversely, years of successful experience with civilian and military aircraft have proven that they are a durable and robust form of transportation, operated with confidence by nuany nations. ${ }^{89}$

Fourth, satellites are simply too far away to sense everything that could be noted by low-flying aircraft. Modern satellites incorporate truly marvelous intelligence technology, but observation fronı an altitude of 1000 feet is bound to be nore revealing than observation fron 100 miles away, especially when cloud cover, air pollution, and darkness intervene. ${ }^{90}$ Unlike satellites, aircraft can take quick advantage of favorable weather conditions and exploit fleeting observation opportunities.

Satellites, Wash. Post, Feb. 25, 1990, at B1, col. 2, B4, cols. 2-3. But see Richelson, supra note 80, at 26 (aircraft have some disadvantages as compared with satelites for reconnaissance purposes, since aircraft have more limited range and speed).

87. The delay in the space shuttle program also caused substantial disruptions in American plans to deploy a comprehensive network of surveillance satellites. Richelson, supra note 86, at B4, col. 2; Sloyan, supra note 62 , at B4, col. 5.

88. There has been substantial debate regarding the technical feasibility of the Strategic Defense Imitiative, but experts agree that it would be significantly easier to shoot down or otherwise interfere with the operation of ordinary satellites (such as those performing reconnaissance or early warning functions) than to intercept ballistic missile warheads, since the satellites typically are not "hardened" against the threat of enemy attack. See generally OFFICE OF TECH. ASSESSMENT, U.S. Congress, Ballistic Missile Defense Technologies (1985) (discussing the technology and feasibility of ballistic missile defense systems); OFFICE OF TECH. ASSESSMENT, U.S. CoNGRESS, ANTI-SATELlITE WEAPONS, CoUnTERMEASURES, AND ARMS CoNTROL 43-45 (1985) [hereinafter ANTI-SATELLITE WEAPONS] (discussing the capabilities and vulnerabilities of satellite systems).

Both the United States and the Soviet Umion have long snstained vigorous research and development programs toward anti-satellite (ASAT) weaponry. Although neither has yet perfected a highly capable system, each has conducted extensive testing. The intermittent arms control negotiations, meanwhile, have made scant progress toward a treaty that might impose a legal solution to the problem of satellite vulnerability. ANTI-SATELLITE WEAPONS, supra, at 127-28; U.S. Dep't of Defense, Soviet Military Power: Prospects for Change 1, 55-56 (1989); see also Grossman, supra note 40, at 19, col. 1 (criticizing Bush adnninistration for pursuing Open Skies proposals while simultaneonsly requesting funds to pursue ASAT capabilities that could jeopardize the best current reconnaissance systems).

89. Another advantage of an Open Skies regime may be the elimination of incidents such as the Soviet Umion's destruction of Korean Air Lines Flight 007 on August 31, 1983, in which one state attacks another state's aircraft in the behef that it is undertaking an espionage overflight. If reconnaissance overflights were legal and cooperative, there would be less reason for states to undertake covert surveillance and less reason for target states to be worried or trigger-happy. See Statement by Jiri Dienstbier, supra note 46 , at 7 . However, such incidents may not entirely disappear if the Open Skies treaty does not authorize SIGINT inissions, and if the states still attempt to collect that type of intelligence via aircraft espionage.

90. Many strategically sensitive areas of the Soviet Union and Eastern Europe are cloudcovered for $70 \%$ of the year, obscuring observation by satellite-based optical systems. Richelson, supra note 63, at 199; Richelson, supra note 86, at B4, col. 3. 
Moreover, for certain purposes, such as the collection of radioactive or chemical debris that might evidence clandestine military activities, airborne sensors are uniquely useful. ${ }^{91}$

\section{Current Open Skies Proposals}

Although the Ottawa and Budapest conferences did not produce a treaty, the resurgence of interest in Open Skies has reinained strong, and a treaty could be concluded in a relatively short time whenever the United States and Soviet Union decide to press for resolution of a few key reinaining obstacles. The current NATO proposal for Open Skies ${ }^{22}$ envisions the following critical elenents, nuany of which represent significant departures fron the pattern of prior arms control accords:

1) All twenty-two nienbers of NATO and the Warsaw Pact ${ }^{93}$ would agree to participate in the program, as both inspectors and hosts. ${ }^{94}$ The entire territory of the United States, the Soviet Union, Europe, and Canada would be available for overflight, with few exclusions, ${ }^{95}$ on an

91. OPEN SKIES AIRCRAFT, supra note 65 , at 4.

92. NATO Press Service, supra note 39.

93. The original NATO proposal embraced all 16 NATO states and 7 Warsaw Pact states. With the reunification of Germany, the number of participating countries has dropped to 22 . During the February 1990 Open Skies negotiations in Ottawa, the direct participants in the talks were the foreign ministers of the 23 NATO and Warsaw Pact states, whilc Austria, Cyprus, Finland, Ireland, Monaco, Sweden, Switzerland, and Yugoslavia sent observers. Open Skies Communiqué, supra note 44.

The impending dissolution of the Warsaw Pact may complicate the bloc-to-bloc structure of the negotiations but will not affect the scope of its geographic coverage. Under the current NATO proposal, the Open Skies program would not apply to the neutral countries of Europe, although it would be "without prejudice" to them, and they might be imvited to join the trcaty at a later time when the inspection regime was operational. NATO Press Service, supra note 39, at 5.

94. The direct participation in the negotiations of so many states is in contrast to the practice of some other arms control agreements, in which bilateral talks between the United States and the Soviet Union were a critical precursor to multilateral involvement. In the case of intermediate-range nuclear forces, for example, the United States and the Soviet Union first negotiated and signed the basic bilateral accord, the INF Treaty, supra note 78 . The parties then worked out a complex uetwork of subsidiary agreements with the European states on whose territory the weapons were based, permitting on-site inspection of the deployment areas. See Agreement Regarding Inspections Relating to the Treaty Between the U.S. and the U.S.S.R. on the Elimination of Their IntermediateRange and Shorter-Range Missiles, Dec. 11, 1987, 27 I.L.M. 58 (1988). In contrast, the CFE Treaty, supra note 7, was negotiated bloc-to-bloc, involving all members of NATO and the Warsaw Pact.

95. Under the NATO proposal, specific locales that pose exceptional hazards to aircraft safety nay be temporarily placed of limits to the inspectors, but even flights over militarily sensitive areas would be restricted only for reasons of safety, such as during a missile test. NATO Press Service, supra note 39 , at 4-5.

This arrangement-providing blanket permission to inspect, subject only to specified exceptions-is in contrast to the inore restrictive inspection powers usually incorporated into other arms control agreements. For example, in the negotiations regarding the control of nuclear weaponry, as well as in the talks concerning an agreement on chemical wcapons, the parties have generally developed programs permitting inspection of specified installations but preventing inspectors from going wherever they might wish, such as into facilities that have no overt connection 
"anytime, anyplace" basis. 96

2) The inspecting state would not need to supply any "reason" for its inspection, and the inspectors would not be required to justify their presence, explain the basis for their proposed flight plan, or provide evidence supporting any suspicions. ${ }^{97}$ The inspectors would conduct their overflights pursuant to a legal right, and the host would be obligated to permit the flights to occur. No additional forms of legal permission, such as licenses or search warrants, would be contemplated. ${ }^{98}$

3) The overfliglits would occur with only very short warning. The inspecting state would give sixteen hours advance notice of its arrival at a port of entry. It would then liave six lours to file a flight plan, followed by twenty-four hours of preflight preparation time. ${ }^{99}$ During the notification period, the states wonld inspect and servicc the aircraft and equipment, and coordinate flight plans for safety purposes. ${ }^{100}$

4) Personnel of the lost country would be permitted to undertake intrusive but nondestructive testing of the aircraft and its sensors to

to the particular type of weapons or industry being regulated. Morrison, Trusting, But Verifying, 1989 NAT'L J. 2580.

96. Toth, NATO, East Bloc Near Accord on Open Skies, L.A. Times, Feb. 13, 1990, at A18, col. 2. In other arms control contexts, such as the START and chemical weapons treaty negotiations, the concept of "anytime, anyplace" inspection for verification has proven controversial, and both the United States and the Soviet Union have shied away from such a high degree of intrusiveness. Morrison, supra note 95 , at 2582.

97. NATO Press Service, supra note 39, at 2. A different sort of arms control inspection regime relies upon "challenge." Under a challenge regime, a party suspicions about events occurring inside another state would present the evidence that triggered its fears and seek an explanation. The challenged state would then supply clarification or agree to host on-site inspection. This sort of regime has been considered most fully in the context of agreenents to limit the testing of nuclear weapons. See H. York, Making Weapons, Talking Peace 304 (1987). The CFE Treaty also uses a similar concept. CFE Treaty, supra note 7, Protocol on Inspection, § VIII.

.98. NATO Press Service, supra note 39, at 2. The principle of reciprocity provides an important protection against abuses, since each state knows that if it misbehaves (as either inspector or host) and frustrates the purposes of the Open Skies regime, then it will likely be treated poorly in return inspections. L. HENKIN, ARMS CONTROL AND INSPECTION IN AMERICAN LAW 22-24 (1958).

99. NATO Press Service, supra note 39, at 4. This time frame is comparable to that incorporated into the INF Treaty, in which the Umited States and the Soviet Umon agreed that the iuspecting party will give sixteen hours advance notice of its entry into the inspected state. The inspecting party will then have four hours to specify which particular facility it wishes to inspect, and the host will then have nine hours to transport the visitors to their intended target. INF Treaty, supra note 78, Protocol Regarding Inspections, 27 I.L.M. 90, 190, reprinted in ACDA TREATY BooK, supra note 2, at 350, 431; Morrison, supra note 95, at 2582; see also CFE Treaty, supra note 7, Protocol on Inspection, $\S$ VIII (establishing similar timetable).

100. NATO Press Service, supra note 39, at 4. The Open Skies aircraft would follow a wide variety of routes, differing from those customarily used by civil aviation, and would want to use starkly varying altitudes at different locations. This would require complex clearances and air traffic control for safety purposes, and a significant portion of the Open Skies regime would include efforts to streamline the existing bureaucratic mechanisms that coordinate this type of transit. Canadian Gov't Press Release, supra note 49, at 1. 
ensure that it contained no weapons or impermissible equipment. ${ }^{101}$ Observers from the host country would remam on board the aircraft during the flight, monitoring its operation and sensors, and they would be permitted unrestricted movenient throughout the aircraft at all times. ${ }^{102}$

5) Each participating state would furnish its own aircraft and sensors for use during the inspection. These could include custon1-built surveillance aircraft or unarmed military planes adapted for the purpose. ${ }^{103}$ Allies could collaborate in performing and hosting their imspections. ${ }^{104}$

6) Sensors could include optical photographic systenis, infrared and thermal sensors, radar imagers, and particulate samplers, but not wiretapping or eavesdropping equipnient. ${ }^{105}$ Sensors would be of very high quality, capable of acquiring detailed data. ${ }^{106}$

7) There would be a quota systeni, based upon the relative geographic size of each participating state, to allocate the number and duration of the overflights, with provisions to ensure rough equality between the two blocs. The United States would be overflown roughly once per week; the Soviet Union twice to three times per week. ${ }^{107}$

8) The inspecting state would share with its allies ${ }^{108}$ the information

101. NATO Press Service, supra note 39, at 4. This arrangement is in partial contrast to that employed in earlier arms control agreements, such as the PNE Treaty, which provided that the inspecting personnel would bring two identical sets of sensing equipınent, and the host state would select one set for use by the inspectors and one set for the host to retain and examine to ensure that no illegitimate extra sensors were hidden inside. PNE Treaty, supra note 78, Protocol, art. IV, If 6, S. Exec. Doc. N, 94tlı Cong., 2d Sess. 5, 15-17 (1976), 15 I.L.M. 891, 896-97, reṕrinted in ACDA TREATY BooK, supra note 2, at 194, 203-04.

102. NATO Press Service, supra note 39, at 4.

103. Id. The current NATO proposal would not permit the use of helicopters. Id. American officials have conteinplated use of large aircraft such as the Lockheed C-135, especially to inspect a large country like tlie Soviet Union. Sinaller aircraft, such as the Boeing DHC Dasli 8-300, could be used for more geographically limited missions. Air Force personnel would probably operate the planes. Open Skies Overflights, supra note 82, at 107.

104. NATO Press Service, supra note 39, at 4. Holland, Belgiun, and Luxembourg have already indicated that they would plan to pool their resources and undertake joint inspection flights in order to save costs. Adams, Smaller Countries Hope to Reduce Open Skies' Cost, Data Limits, Defense News, Feb. 19, 1990, at 8, col. 1.

105. BACKGROUNDER, supra note 10. Under the NATO proposal, tlie states would develop and update a list of prohibited categories of sensors each year. NATO Press Service, supra note 39, at 4.

106. The United States would be willing to inodify existing export restrictions and sell to the USSR some types of advanced sensors for use in Open Skies. See Hughes, U.S., Soviet Differences Could Prevent Planned Signing of Open Skies Treaty, Aviation WEEK \& SPACE Tech., Apr. 2, 1990, at 41-43; Morrison, supra note 20, at 3020; Notes from Canadian Open Skies Press Conference, supra notc 82, at 2 (comnents by Ambassador Burney).

107. NATO Press Service, supra note 39, at 4. Under the NATO proposal, a country would get a quota on the basis of its geographic size. Id. at 3 . Since the Soviet Union is more than twice as large as the United States, the United States could conduct more than twice as many surveillance fights over the Soviet Umion as the Soviets could conduct over the United States. STIMSON CENTER, supra note 37, at 2.

108. The ongoing political reconfiguration of Europe complicates the prior focus on the bloc-to- 
obtained from Open Skies overflights, ${ }^{109}$ but the host state and its allies would not receive copies of the data. ${ }^{110}$

Most of the Warsaw Pact countries ${ }^{111}$ have not dissented from these propositions in critical ways, but the Soviet Union has expressed contrary views on several outstanding questions. ${ }^{112}$ Primary among these points of contention have been the Soviet suggestions that:

1) The overflying aircraft should be owned and operated by the host state, or perhaps jointly owned and operated by both countries, instead of belonging to the inspecting state. The states could develop and build a dedicated multinational fleet of reconnaissance aircraft for this purpose, and could use a common package of sensors. ${ }^{113}$

bloc negotiation and implementation of Open Skies. Analysts have pondered who would have the responsibihty and authority to overfly a reunited Germany, whether Greece and Turkey would overfly each other, and how the former satellite states of Eastern Europe would now relate to the Soviet Umion. Horgan, Open Skies, 262 ScI. AM., May 1990, at 5, 20-21.

109. NATO Press Service, supra note 39, at 4-5. American officials concede that the interpretation of the data obtained from Open Skies overflights will be challenging, but contend that existing procedures for sharing similar information within the NATO alliance can continue. STIMSON CENTER, supra note 37, at 6; see also Katz, The Fabric of Verification: The Warp and the Woof, in VeRIFICATION AND SALT, supra note 26, at 199 (photographs can be very compelling evidence about behaviors, but interpretation by skilled analysts is necessary before photos can be meaningful to non-experts).

110. NATO Press Service, supra note 39, at 4-5. In contrast, most other arms control agreements, such as the Peaceful Nuclear Explosions Treaty, have dealt with this question by specifying that host country persounel should accompany the inspectors, replicate any measurements as they see fit, and obtain copies of all photographs. The two parties then jointly control the release of any information acquired during the inspection. PNE Treaty, supra note 78, Protocol, art. III, If 5, art. IX, If 2, S. Exec. Doc. N, 94th Cong., 2d Sess. 5, 13-14, 22 (1976), 15 I.L.M. 891, 895-96, 900, reprinted in ACDA TREATY Book, supra note 2, at 194, 202, 209.

111. Diplomatic fissures have appeared within the Warsaw Pact on the question of Open Skies. During the Ottawa conference, Czechoslovakia and Hungary distanced themselves somewhat from the position adopted by the Soviet Union. 9 Arms Control Rep. (IDDS) 409.B.11 (Mar. 1990). Some fear that this disarray may delay an agreement on Open Skies. Howard, Soviets Gain Little Support for Proposal, Globe and Mail, Feb. 5, 1990, at A4, col. 6.

112. See L. DunN \& B. HENRY, supra note 37, at 5-13; B. HENRY \& R. DAVIS, supra note 37, at 6-7; Tucker, supra note 37, at 22-23. The Soviet Union and the Warsaw Pact nations issued their own point-by-point "basic elements paper" in response to NATO's position paper, see Warsaw Treaty Organization, Basic Elements Paper on Open Skies, Opens Skies Conference, Ottawa (Feb. $12,1990)$, and other aspects of their views have emerged in speeches at Ottawa and in informal contacts. See 9 Arms Control Rep. (IDDS) 409.B.9-11 (Mar. 1990); USSR Foreign Ministry Press Center, Questions From the Press, VESTNIK, Mar. 1990, at 80 (interview with Soviet anns negotiator Viktor Karpov) (VESTNIK is a joimt publication of the USSR Foreign Ministry and the Anstrian firm of Allgemeine Bauten-Vertriebsgesellschaft); Lewis, supra note 11, at A11, col. 1; Statement by Jiri Dienstbier, supra note 46; Statement by Boyko Dinitrov, Minister for Foreign Affairs, Bulgaria, Open Skies Conference, Ottawa (Feb. 12, 1990).

113. See Open Skies Overfights, supra note 82, at 107; Adams \& Lowman, supra note 49, at 25, col. 1. Some commentators speculate that one reason for this preference is that the Soviet Umion's surveillance equipment is not as sophistieated as that of the United States. See Morrison, supra note 20, at 3020. Pooling resources would equalize the types of data collected and perhaps permit the Soviets to acquire Western technology. See Howard, Open Skies, and Open Secrets, Globe and Mail, Jan. 23, 1990, at A7, col. 1. Reliance upon host-owned aircraft and sensors would also eliminate the 
2) There should be a smaller quota of permitted overflights, such that the Soviet Umion might host approximately fifteen to twenty-five Open Skies inspections per year, with another fifteen to twenty-five annually for the rest of the Warsaw Pact. Each flight would be of limited duration, with the sensors operating for only three hours of the flight. ${ }^{114}$

3) A more restricted package of sensors should be available for Open Skies flights, using ouly photography and relatively primitive synthetic aperture radars, while eliminating the most technologically sophisticated devices. The permitted sensors should possess relatively limited capabilities and would not be the best available in the West. ${ }^{15}$

4) The treaty should permit broader exclusions from observation, and certain sensitive locations should be declared off limits to Open Skies overflights.

5) The participants should be allowed to overfly one another's overseas military bases as well as their home territories. ${ }^{116}$

6) Each inspecting state should share the photographs and other data it acquires with all the other parties to the treaty, not solely with members of its own military alliance. ${ }^{117}$

7) The spirit of the negotiations should also lead to a subsequent treaty embracing exchanges of information about military activities on the high seas and in outer space ("open seas" and "open space" as well as "open skies"), since these, too, are areas where potential threats exist. ${ }^{118}$

\section{E. The Importance of Open Skies}

Why are the superpowers and their allies, after ignoring the concept of Open Skies for so long, suddenly so eager to pursue it? ${ }^{119}$ What is its

possibility that the inspectors could secretly insert additional types of equipinent beyond those authorized by the treaty.

114. See Krepon, supra note 36, at M2, col. 3.

115. See 9 Arms Control Rep. (IDDS) 409.B.16 (July 1990); Krepon, supra note 36, at M2, col. 3.

116. See 9 Arms Control Rep. (IDDS) 409.B.15 (July 1990). The Soviet Union has noted that the United States maintains a far-flung network of naval and air bases around the world, and has argued that these installations, too, ought to be subject to Open Skies inspections. Howard, Soviets Seek Changes in Scheme for Surveillance, Globe and Mail, Jan. 9, 1990, at A9, col. 1. Many of the states participating in Open Skies negotiations have important military bases or other activities inside other countries. 'See Sivard, World Military and SocIal EXPENDITUREs, 1987-88, at 12-13 (12th ed. 1987) (listing 29 countries with a total of 1,771,360 troops based abroad in 1987).

117. USSR Foreign Ministry Press Center, supra note 112, at 80; Warsaw Treaty Organization, supra note 112, at 1.

118. Lewis, supra note 43, at A10, col. 1; Statement by Eduard Shevardnadze, Open Skies Conference, Ottawa (Feb. 12, 1990), at 3-4, reprinted in Shevardnadze, Open Thinking Opens the Skies, VESTNIK, Apr. 1990, at 60-61.

119. Many delegations praised the effectiveness of the Ottawa round of negotiations and expressed satisfaction with the rapid progress recorded there. Open Skies Comnnuniqué, supra note 44 , at $1-2$. 
place in the modern world of arms control and national security? Both pohtical and military considerations help explain the sudden renaissance. ${ }^{120}$

Politically, agreement on an Open Skies treaty would provide an important deinonstration of mutual good will. Secretary Baker has suggested that an Open Skies agreeinent would provide "a tangible and powerful symbol of einerging East-West cooperation that our public can readily see and understand." 121 This treaty and the unprecedented exposure it mandates could highlight a drannatic break witl past policies of secrecy and distrust. ${ }^{122}$ Open Skies could help symbolize a new era in which nations, motivated by the liope that greater inutual openness could reciprocally reduce the fear of surprise attack, willingly exposed theinselves to foreign scrutiny. ${ }^{123}$ This openness could also reduce tlie dual tendency to apply "worst case scenarios" to perceived threats from the other side and to respond by maintaining a large, expensive, and threatening military apparatus. ${ }^{124}$

Open Skies by itself does not reduce the number of armaments a state may possess. Indeed, paying tlie costs associated with conducting inspections and performing liost functions would marginally increase total military expenditures. ${ }^{125}$ Nonetheless, Open Skies would eventually

120. See L. DunN \& B. Henry, supra note 37 , at 14 (listing the possible purposes of Open Skies); B. HENRY \& R. DAvis, supra note 37, at 8 (same); Tucker, supra note 37, at 20 (describing the utility of an Open Skies treaty).

121. Lewis, supra note 43, at A10, col. 1; Stateinent by U.S. Secretary of State James A. Baker III, Open Skies Conference, Ottawa (Feb. 12, 1990), reprinted in Baker, Open Skies and the New Era in Security, U.S. Dep't of State, Press Release No. 17 (Feb. 14, 1990).

122. Some earlier arms control negotiations witnessed exceptionally difficult and painstaking deliberations regarding what, if any, photographs the inspecting personnel would be allowed to take and what procedures would be necessary to protect the interests of the host state when photography was permitted. See PNE Treaty, supra note 78, Protocol, art. III, I 5, S. Exec. Doc. N, 94th Cong., 2d Sess. 5, 13-14 (1976), 15 I.L.M. 891, 985-96, reprinted in ACDA TREATY BooK, supra note 2, at 194, 202; Heckrotte, Verification of Test Ban Treaties, in VerIFICATION AND ARMS ConTroL, supra note 59 , at $63,67-68$.

123. Of course, the states have already exposed themselves, willingly or not, to satellite reconnaissance, and this type of surveillance-both by the superpowers' military satellites and by privately owned commercial satellites operated for news-gathering and other purposes-is becoming more intrusive and pervasive. Lindgren, Commercial Satellites Open Skies, 44 Bull. ATOM. SCIENTISTS, Apr. 1988, at 34.

124. President Lyndon Johnson described the value of the early reconnaissance satellites in similar terms, noting that the $\$ 35-40$ billion the United States spent on the space program was a valuable investment:

[I] nothing else had come out of it except the knowledge we've gained from space photography, it would be worth ten times what the whole program has cost. Because tonight we know how inany missiles the enemy has and, it turned out, our guesses were way off .... We were harboring fears we didn't nced to harbor.

Richelson, supra note 86, at B1, col. 3, B4, col. 1 .

125. One expert has estimated that the cost of building and outfitting a sniall airplane for an Open Skies operation would be $\$ 12$ million, with another $\$ 3$ unillion in annual operating costs. Morrison, supra note 20, at 3020 . 
promote other weapons cuts by evidencing states' benign intentions and easing international tensions. For example, one commentator has noted that the justification for expensive, radar-evading Stealth bombers could be undercut by an Open Skies treaty that provided for regular unencumbered reconnaissance flights over the Soviet Umion. ${ }^{126}$

Open Skies also quiets the hoary debates about how much verification is necessary and appropriate for what measure of disarmament. The United States and the Soviet Union have long disagreed over whether the "control" provisions of an imternational system could conie before, with, or ouly after the "disarmament" provisions had been implemented. The United States has traditionally argned that it would not be safe to reduce armanients before establishing a workable verification apparatus, and the Soviets have frequently countered that no mvasive noonitoring arrangenents would be worthwhile or necessary before truly significant arins reductions were achieved. ${ }^{127}$ By establishing the precedent that, at least im sone areas, the verification systen 1 can conie first, with the substantive arins control measures to follow, an Open Skies treaty would help resolve this particular point of contention. At a time when Europe, and the world as a whole, are racing toward niutual accommodation, ${ }^{128}$ Open Skies could be a timely and salient gesture. ${ }^{129}$

Reaching an agreement on aerial mspection, however, will serve nuore than purely symbolic ends. Open Skies also has a vital military coniponent because of its considerable value to strategic and tactical intelligence. As noted previously, aircraft can perfornn some reconnaissance functions nore deftly, rehably, and cheaply than satellites, ${ }^{130}$ and certain types of data can be acquired only through the proximate sensing

126. Krepon, "Open Skies"-Money in the Bank, N.Y. Times, Feb. 19, 1990, at A17, col. 1.

127. See A. Krass, supra note 20, at 116; see also Stanford Arms Control Group, INTERNATIONAL ARMS CONTROL: IsSUeS AND AGREEMENTS 71-72 (J. Barton \& L. Weiler eds. 1976).

128. There is a strong connection between Open Skies and other arms control efforts designed as "confidence-building measures." Steps like those being considered in the Conference on Security and Cooperation in Europe will not directly reduce the size of the participating states' military forces, but are intended to reduce the potential for, and the fear of, surprise attack. See NATO Press Service, supra note 39, at 1. American and Soviet officials agreed that an Open Skies treaty should not be legally connected to other ongoing negotiations, such as those that produced the CFE Treaty, supra note 7, in November 1990, even though there is an important military and political link between thein. 8 Arms Control Rep. (IDDS) ๆ 850-211 (Nov. 1989). An Open Skies treaty would cover a larger geographic area than the CFE Treaty, and would permit overflight and photography without regard to any particular program of arms reductions. See Notes from Canadian Open Skies Press Conference, supra note 82 (comments by Ambassador Burney).

129. An Open Skies regime would not be foolproof; its proponents recognize that there would always be opportunities for obstrnctionist parties to frustrate it without overtly violating its provisions. Nevertheless, they argne, the treaty can be a useful step in building and sustaining the joint political will necessary to make the inspection program succeed. BACKGROUNDER No. 2, supra note 17 , at 11.

130. See supra text accompanying notes 79-91. 
that Open Skies would authorize. ${ }^{131}$

Moreover, even if Open Skies inspections were nothing more than a backup means of verification, and the treaty were simply an authorization for a redundant system of aerial overflight, it would still make a contribution at the margin, further comphicating the task of any potential arms control violator and providing insurance against failure of the primary system. ${ }^{132}$ The combimation of a satellite's technical elegance and an airplane's robustness and flexibility provides the kind of synergistic assurance that neither system standimg alone could offer. ${ }^{133}$

A solid Open Skies agreenent could therefore contribute to imternational security by increasing each side's confidence that its potential adversaries were not undertaking threatening military activities in contemplation of war. ${ }^{134}$ Aerial overflight could compleinent inore distant or episodic forms of inspection, ${ }^{135}$ assisting in the performance of a variety of intelligence functions. By establishing a system of regular, close, and focused observation, Open Skies could lielp ensure compliance witl current or future arms control treaty terms such as those that require a party rehably to: (a) count the strategic nuclear weapons of other states

131. See supra text accompanying notes 63-74.

132. Modern arms control agreements depend upon multiple verification systems. No single mechanism, no matter how powerful, is ordinarily considered sufficient to monitor comphance, and a network of overlapping and partially redundant means of detection provides the grcatest assurance of adequate verification. A. KRASS, supra note 20 , at 98-101.

133. Moreover, the imagery that satellite photorcconnaissance produces for national security purposes has traditionally been heavily classified in order to prevent the compromise of intelligence sources and inethods that might accompany public release. See Limdgren, supra note 123, at 37. Aerial photography, on the other hand, could probably be disseminated freely, which could further increase confidence by facilitating informed public debate. OPEN SKIES AIRCRAFT, supra note 65, at 4; Krepon, supra note 37 , at 27 , col. 1 .

134. No state is willing to accept nncorroborated, unilateral assertions that a potential rival has scrupulously complied with all treaty obligations. Some mechanism for verifying such performance is therefore necessary. While the standards defining the "adequacy" or "effectiveness" of verification remain controversial, there is general acknowledgment that no realistic system of monitoring could ever provide $100 \%$ certain detection of violations. See D. BARASH, supra note 64, at 240-41 ("The probability of obtaining absolute verifiability would seem to be very low, almost zero."); see also Krepon, The Political Dynamies of Verification and Compliance Debates, in VERIFICATION AND ARMS CONTROL, supra note 59, at 135 ("[I]t was not reasonable to expect either perfect confidence in U.S. monitormg capabilities or treaty constraints that allowed absolute certainty in momitoring coniphance.").

135. Arms control agreements increasingly provide for "on-site inspection"; under such an arrangenient, foreign personnel would be dispatched to observe events firsthand and take appropriate ineasurements and samples to resolve compliance ainbiguities. See PNE Treaty, supra note 78, art. IV, If 1(b), S. Exec. Doc. N, 94th Cong., 2d Sess. 5, 6 (1976), 15 I.L.M. 891, 892, reprinted in ACDA TREATY BooK, supra note 2, at 194, 195; INF Treaty, supra note 78, Protocol Regarding Inspections, 27 I.L.M. 90, 190, reprinted in ACDA TREATY BooK, supra note 2, at 350, 431. In many instances, these on-site inspections would provide a valuable verification tool, deterring violations and complicating the task of evasion, but even then they would not be foolproof. Heckrotte, On-Site Inspection to Check Compliance, in NUClEAR WEAPON TESTS: ProhibITION OR Limitation 247-60 (J. Goldblat \& D. Cox eds. 1988). See generally Schear, supra note 75, at 24-30 (discussing the importance and limitations of on-site inspection). 
and assess their capabilities; ${ }^{136}$ (b) determine the status and location of intermediate-range nuclear forces and the progress made toward dismantling them; ${ }^{137}$ (c) monitor various types of traffic nito and out of potential chemical weapons facilities; ${ }^{138}$ (d) observe events at nuclear weapons testing grounds and collect any telltale radioactive debris from clandestine explosions; ${ }^{139}$ (e) oversee miliary nıaneuvers and formations in order to count and classify conventional troops and equipment; ${ }^{140}$ and (f) perform other types of momitoring activities that are niore difficult or expensive when confined to earthborne or satellite sensors. ${ }^{141}$ Open Skies overflights will not by theniselves suffice for these diverse applications, but they can certainly augment existing verification capabilities. ${ }^{142}$

\section{II \\ Preliminary Legal Issues}

Before evaluating in detail the constitutional implications of an Open Skies regime, we nuust resolve three threshold inquiries. These concern (a) the legality of overflight of American territory; (b) the degree

136. See SALT II Treaty, supra note 76, arts. III \& IV, S. Exec. Rep. No. 14, 96th Cong., 1st Sess. 319, 360-89 (1979), 18 I.L.M. 1138, 1144-48, reprinted in ACDA TREATY BOoK, supra note 2, at $267,274-81$.

137. See INF Treaty, supra note 78, art. XI, 27 I.L.M. 90, 95-96, reprinted in ACDA TREATY Book, supra note 2, at 350, 359-61.

138. See Memorandum of Understanding Regarding a Bilateral Verification Experiment and Data Exchange Related to Prohibition of Chemical Weapons, Sept. 23, 1989, United States-USSR, 28 I.L.M. 1438 (1989); U.S. Draft Convention on the Prohibition of Chemical Weapons, submitted to the Conference on Disarmament, Apr. 18, 1984 (bilateral verification experiment and data exchange related to prohibition of chemical wcapons); Tanzman, Constitutionality of Warrantless On-Site Arms Control Inspections in the United States, 13 YALE J. INT'L L. 21, 44-55 (1988).

139. In the context of trcaties regulating or prohibiting the testing of nuclear wcapons, aerial overflights could be useful for purposes of detecting the emission of telltale radioactive particles. Din, Means of Nuclear Test Ban Verification Other Than Seismological, in NUCLEar WEAPONS TESTS 241-43 (J. Goldblat \& D. Cox eds. 1988); see Heckrotte, supra note 135, at 256 (specifying where to concentrate attention in an on-site inspection); Richelson, supra note 63, at 197 ("[A]erial sampling is employed to detect the atomic particles emitted by a nuclear explosion.").

140. See B. Mandell, The Sinai Experience: Lessons in Multimethod ARms Control VERIFICATION AND RisK MANAGEMENT 21-22 (1987) (discussimg use of overflights to monitor Egyptian and Israeli troops and armaments); Stovall, supra note 59, at 4-12 (describing inspections undertaken pursuant to Stockholm Document); Krepon, supra note 37, at 27, col. 3 (noting that during the process of disengagement from the Sinai Peninsula, Egypt and Israel relied upon the United States to conduct periodic aerial overflights and mimediately release the imagery to both sides).

141. If an Open Skies agreement is implemented and aerial overflights become commonplace, the resulting data would become $\mathfrak{a}$ routine component of each participating state's intelligence structure. The states could then apply the photographs and other products to the full range of national security issues, including as yet unimagined applications in arms control and other fields.

142. See Perry, supra note 32, at 19-20 (describing utility of Open Skies in monitoring modern arms control agreements effeetively yet unobtrusively); Krepon, supra note 37, at 27, col. 1 (states should adopt an Open Skies regime, which would complement other inonitoring arrangements for arms limitation); see also Danson, supra note 72, at 7, col. 1 (suggesting that a follow-on accord to an Open Skies agreement could provide for cooperative satellite reconnaissance). 
of state action by United States officials; and (c) the delegation of sovereign functions to alien personnel.

\section{A. Overflight of American Territory}

Under international law, each sovereign nation has plenary authority to regulate the navigable airspace above its territory. ${ }^{143}$ A nation may exclude alien aircraft altogether, limit their presence, or authorize various sorts of overflights and landings. ${ }^{144}$ Airspace differs sharply in this respect from outer space, where international law generally forbids a subjacent conntry froin asserting sovereign authority. ${ }^{145}$

In the United States, it is well settled that the federal government, rather than the states, exercises this sovereign authority over airspace, and most legal issues relatimg to flight are federal questions. ${ }^{146}$ Accordingly, the federal government has established programs to regulate and monitor air traffic, and it has assunied responsibility for air safety and other pubhic functions. It is also well settled that the federal government retains the authority to use or hicense the superjacent airspace of private landowners. Terrestrial property rights do not include the right to keep

143. See Convention on International Civil Aviation, Dec. 7, 1944, art. 1, 61 Stat. 1180, 1180, 15 U.N.T.S. 295, 296. No state concedes or clains any inherent right of "innocent passage" through the airspace of another state. L. HENkin, R. PuGH, O. SCHACTER \& H. SMIT, INTERNATIONAL LAw 842 (2d ed. 1987). Under the United Nations Convention on the Law of the Sea, each state also controls the airspace above its territorial sea, but aircraft of other states do have a right of "transit passage" over international straits and archipelagic waters. United Nations Convention on the Law of the Sea, opened for signature Dec. 10, 1982, arts. 2, 37-39, 42-44, 53-54, U.N. Doc. AV Conf.62/122 (1982), reprinted in U.N., THE LAW OF THE SEA: OFFIC1AL TEXT OF THE UNITED Nations CONVENTION GN THE LAW OF THE SEA WITH ANNEXES AND INDEX, U.N. Doc. LOS/ Z/1, U.N. Sales No. E.83.V.5 (1983), 21 I.L.M. 1261, 1272, 1276-79 (1982).

144. D. ARoNowitz, LEgal ASPECTS OF ARMS CONTROL VERIFICATION IN THE UNITED STATES 50 (1965). Ordinarily, states negotiate treaties to ensure reciprocal rights to overfly each other's territory and to land for various commercial and other purposes. A complex network of bilateral and inultilateral agreements governs international air traffic. L. HENKiN, R. PUGH, O. SCHACTER \& H. SMIT, supra note 143, at 267. An Open Skies agreement would have the effect of "'streamlining' existing bureaucratic inechanisms for handling international air traffic so that requests for overfight clearances on coinplex and unique routes can be dealt with expeditiously by national authorities." Open Skies: Preparing for THE 1990s, Backgrounder No. 3, Report on the Canada-Hungary Trial "Open Skies" Overflight 1 (1990).

145. See Treaty on Principles Governing the Activities of States in the Exploration and Use of Outer Space, Including the Moon and Other Celestial Bodies, Jan. 27, 1967, art. II, 18 U.S.T. 2410, 2413, 610 U.N.T.S. 205, 208; L. HENK1N, R. PUGH, O. SchaCTER \& H. SMIT, supra note 143, at 1366-67. The United States, the Soviet U1rion, and most other countries have generally acknowledged the legality of satellite overflight and reconnaissance, although the matter is not entirely free froin controversy. See Principles Relating to Remote Sensing of the Earth From Outer Space, G.A. Res. 41/65, 41 U.N. GAOR Supp. (No. 53) at 115, U.N. Doc. A/41/53 (1986); Krass, supra note 59 , at 46-48. As satellite surveillance, including sensing by privately owned commercial spacecraft, becoines more comnon and more powerful, see Lindgren, supra note 123, at 35-37, more legal controversies may arise.

146. See 49 U.S.C. app. $\$ 1508(a)$ (1988); id. app. $§ 1304$ (1988); D. ARonowITz, supra note 144, at 136-37; L. HENKIN, supra note 98, at 33, 51. 
others out of the navigable airspace, ${ }^{147}$ and overflight of a landowner's domain does not constitute a trespass or a "taking" unless the flights are so noisy, low, and frequent that they seriously disrupt enjoyment of the property. ${ }^{148}$ Therefore, with regard to the physical use of American airspace, the federal government could lawfully create a regime of Open Skies overflights, and the concerns of local governments or of individual property holders would not create substantial impediments.

\section{B. Degree of State Action}

The fourth annendment limits the activities of the Umited States government, not private or foreign actors. ${ }^{149}$ Therefore, if courts construed Open Skies overflights not as U.S. Government actions but merely as the actions of foreign countries or of individual foreign nationals, then no fourth amendment restrictions would likely apply. ${ }^{150}$ Under that scena-

147. See United States v. Causby, 328 U.S. 256, 266 (1946) ("The airspace, apart from the immediate reaclies above the land, is part of the public domain.").

148. See Griggs v. Allegheny County, 369 U.S. 84, 88-89 (1962) (aircraft greatly disrupting a property owner's use of the overflown land constitutes a takiug); Causby, 328 U.S. at 266 (aircraft overflights causing direct and immediate interference with the use of private land constitute a taking). But see Pueblo of Sandia ex rel. Chaves v. Smith, 497 F.2d 1043, 1046 (10th Cir. 1974) (traversing air space over plaintiff's unimproved land is not a trespass). For a discussion of property owners' right to airspace, see D. ARONowITZ, supra note 144, at 137. See generally Annotation, Airport Operations or Flight of Aircraft as Constituting Taking or Damaging of Property, 22 A.L.R. 4TH 863 (1983) (reviewing cases clainimg inverse condemnation based on aircraft overflights at varying altitudes or on aircraft testing).

149. Burdeau v. McDowell, 256 U.S. 465, 475 (1921) (fourth amendment protects individuals from government searclies and does uot protect against action by nongovernment actors). Later cases lave attempted, with limited success, to establish what constitutes a government search. See New Jersey v. T.L.O., 469 U.S. 325, 333 (1985) (fourth amendment protects individuals from searclies by all government agents, not solely from those by law enforcement officers); United States v. Jacobsen, 466 U.S. 109, 113 (1984) (governmeut may repeat, and somewhat expand, the plain view observations unade by a private party witlout enlarging the private intrusion into a government searcl); Katz v. United States, 389 U.S. 347, 350-51 (1967) (Constitution protects personal privacy from governmental imvasion, but person's "right to be let alone by otler people" is a matter of state law); Berlin Democratic Club v. Rumsfeld, 410 F. Supp. 144 (D.D.C. 1976) (if German police automatically implemented Urited States Army's "suggestions" about installing wiretaps against American nationals residing in Germany, the activity would be a joint venture and constitutional restraints would apply).

150. See Blum v. Yaretsky, 457 U.S. 991, 1004-05 (1982) (government can be held liable for actions of private parties only where it las "exercised coercive power or has provided such significant encouragennent, either overt or covert," that it is responsible for the private parties" actions); Committee of United States Citizens Living in Niearagua v. Reagan, 859 F.2d 929, 946-47 (D.C. Cir. 1988) (whlere U.S. governnent funded operation of Nicaraguan rebels but did not participate in their activities, there was insufficient state action to implicate fourth alnendment); $c f$. Umited States v. Ramirez, 810 F.2d 1338, 1342 (5th Cir. 1987) (fourth amendment inapplicable where hotel manager who searcled defendant's luggage was not acting as government agent or instrument); United States v. Walsl, 791 F.2d 811 (10th Cir. 1986) (where airline employee's original private searcl of briefcase revealed contraband, subsequent investigation by federal authorities was not a searcl1); Williams v. State, 257 Ga. 788, 364 S.E.2d 569 (1988) (where police did not instruct or request lospital staff regarding removal of a bullet from defendant, operation was not a government searcli). 
rio, only state tort laws protecting against invasion of privacy ${ }^{151}$ or conversion of trade secrets through the unfair competition of illicit spying ${ }^{152}$ would regulate the activity. The Foreign Sovereign Immunities Act, ${ }^{153}$ which prohibits the assertion of jurisdiction over a foreign state or official regarding his or her "discretionary function,"154 would hamper even these private remedies.

One might argne that courts should not characterize Open Skies overflights as federal actions. Under the current NATO proposal, the foreign state-not the United States Government-would own and operate the aircraft. ${ }^{155}$ Foreign personnel would guide and direct the aircraft, and would also decide where and when to fly, what altitudes to use, what pictures to take, and how to nrake use of the acquired miagery. ${ }^{156}$ The United States would simply facilitate the operations, ensure coinphiance

151. The tort of "invasion of privacy" or "intrusion upon seclusion" is applicable to "one who intentionally intrudes, physically or otherwise, upon the solitude or seclusion of another or his private affairs or concerns ... if the intrusion would be highly offeusive to a reasonable person." RESTATEMENT (SECOND) OF TORTS $\S 652 B$ (1977). The elements of the tort do not usually require any physical entry into a private space (the invasion can be accomplished through the use of human senses, including senses augmented by artificial means), or that the intruder use or publicize the acquired information in any way. Id.; see Birnbaum v. Umited States, 588 F.2d 319, 323-26 (2d Cir. 1978) (defining a violation of the freedom from unreasonable intrusion as a part of the tort of invasion of privacy); Pearson v. Dodd, 410 F.2d 701, 704 (D.C. Cir.) (tort of intrusion upon privacy does not require physical trespass into private space, or use or publication of the obtained information), cert. denied, 395 U.S. 947 (1969). But see Anderson v. Fisher Broadeasting Co., 300 Or. 452, 712 P.2d 803 (1986) (television broadcaster's commercial use of videotape of accident victim held not an invasion of privacy).

152. The tort of misappropriating trade secrets is established when an actor takes valuable commercial facts improperly, either by breaching a confidential relationship or otherwise. See E.I. duPont deNemours \& Co. v. Christopher, 431 F.2d 1012, 1015 (5th Cir. 1970) (Texas law provides a cause of action for use of improper means of industrial espionage, where a competing firm hired aircraft to overfly a chemical plant under construction and the resulting photograplis could revcal trade secrets that could have been protected only via unreasonably expensive roofing), cert denied, 400 U.S. 1024 (1971); USM Corp. v. Marson Fastener Corp., 379 Mass. 90, 101, 393 N.E.2d 895, 902 (1979) (corporation need undertake proper and reasonable protective steps, but not heroic ineasures, to preserve the privacy of trade secrets).

153. 28 U.S.C. $\$ \S 1330,1391,1441,1602-1611$ (1988). The "act of state doctrine" would not be applicable to Open Skies activities, simcc that legal principle bars judicial inquiry into the legitimacy of state actions ouly when the acts in question were undertaken by a foreign sovereign inside its own territory. Restatement (THIRD) OF THE Foreign RELATIONS LAW OF THE UNITED STATES $\S 443$ (1980). For Open Skies, in contrast, the foreign state's acts of inspection would be accomplished entirely inside United States territory. See Iraq v. First Nat'1 City Bank, 353 F.2d 47 (2d Cir. 1965) (act of state doctrine would not be applied where government of Iraq attempted to nationalize bank deposits and shares of stock held in New York by deposed King).

154. 28 U.S.C. $\$ 1605(\mathrm{a})(5)(\mathrm{A})$ (1988); see Dalehite v. United States, 346 U.S. 15, 36 (1953) (a discretionary act is one in which "there is room for policy judgment and decisions"); cf. Letelier $\mathbf{v}$. Republic of Chile, 488 F. Supp. 665 (D.D.C. 1980) (Chile not entitled to immunity because the statutory exccption for discretionary functions did not cover illegal actions such as political assassination).

155. See Nato Press Service, supra note 39, at 3.

156. See id. at 4-5. 
with legal regulations, and guard against abuses. ${ }^{157}$ According to this characterization, the federal government would be no more liable for Open Skies overflights than the federal government is now liable for commercial airline overflights. ${ }^{158}$

Moreover, in contrast to most other arms control imspection systems, Open Skies requires no "entry" onto private property and no overt "compulsion" of the citizenry. ${ }^{159}$ Overflown mdividuals or busmesses would not be required to cooperate in any way; the treaty would leave them free to conceal their activities and otlierwise to deny information to the aircraft sensors. ${ }^{160}$ Because Open Skies does not rely upon governinent autliority to mandate disclosure or collaboration by the citizenry, ${ }^{161}$ and because a state would impose no pumshment for tliwarting the mspectors, ${ }^{162}$ the program is arguably not state action at all. ${ }^{163}$

157. See id. at 4.

158. See Griggs v. Allegheny County, 369 U.S. 84, 89 (1962) (where aircraft frequently and noisily overflew private property on landing and takeoff, responsibility for the infringement on property rights lay with the local county airport authority, instead of with the federal government, which had merely established regulations for safe flight plans).

159. StIMSON CENTER, supra note 37. Under an Open Skies treaty, the inspectors would simply fly over the target and not disturb the activities below. The verification arrangements in some arms control treaties, in contrast, could call for the foreign inspectors physically to enter regulated facilities to ensure that no impermissible weapons-related activities are occurring inside. The host government would be obligated to find a legal mechanisin to permit these on-site inspections, which could include forcible entry into commercial—or even residential—buildings without the owner's consent. See Tanzman, supra note 138 (describing the verification provisions and the attendant legal coinphications of the nascent chemical weapons convention).

160. Many existing arms control agreenents prohibit both "interference" with national technical means (NTM) of verification and "deliberate concealınent" of relevant activities froin NTM. See Cohen, supra note 29 , at 60-65; supra note 76 . Under these agreenents, for example, the United States Government would be prohibited from damaging a Soviet reconnaissance satellite in space or building an opaque shelter over the American missile silos that the satellite was attempting to inoritor. Moreover, the governinent would be obligated to ensure that no private American citizens were undertaking similar activities that could undercut the object and purpose of the treaty.

Under an Open Skies agreement, in contrast, the obligations on both the government and the citizenry would be less onerous. The treaty would probably prohibit "interference" with the operation of the aircraft and its equipment; for example, neither the government nor private persons could lawfully shoot at the plane, shine blinding hights into its cameras, or eleetronically "jain" its other sensors. But the Open Skies treaty would not prohibit any kind of "deliberate concealment" by the government or the citizenry. STIMSON CENTER, supra note 37. Thus, unless some other current or future arms control agreenent requires that a particular item or site be exposed to view, its owner or operator could legally withdraw it from observation by erecting a roof over it, bringing it indoors, camouflaging it, or using it only under the cover of darkness or clouds or when no overflights are occurring.

161. See Nato Press Service, supra note 39 (aerial surveillance is the only mcans of inspection provided for in the Open Skies proposal).

162. See id. (Open Skies proposal eontains no provision for punishnent).

163. A somewhat analogous area concerns "administrative searches" (for example, inspections by municipalities to ensure compliance with zoring codes, fire safety ordinances, or public health standards). At one time, the Supreme Court had determined that because these searches were short, nonpenal, and relatively nonthreatening to the target, they had only "peripheral" importance for constitutional concerns and were wholly outside the scope of the fourth amendment's warrant 
The better view, however, is that Open Skies does involve state action and therefore implicates constitutional concerns. ${ }^{164}$ The United States would be intimately involved in the program and should have responsibility for inamtaining fourth amendment standards. As an initial matter, the entire scheme of Open Skies is a government undertaking, authorized by the constitutional grant of power over foreign affairs, ${ }^{165}$ and designed to enable the federal government to accomphish important public purposes; it is not simply the hicensed commercial activity of private foreign actors. ${ }^{166}$ Moreover, federal officials will actively participate in the enterprise by inspecting aircraft and equipment for compliance with treaty provisions, and federal officials will acconipany all flights. ${ }^{167}$ They will momitor the performance of the airborne plane and its sensors, and they may replicate the measureinents. They will constantly accompany the foreign personnel while in this country, assuming responsibility for trouble-free operations. In some instances, federal officials may help fly the airplane. ${ }^{168}$

The law remaims unclear regarding what level of governmental participation suffices to convert an otherwise private action into a public action for fourth amendment purposes. ${ }^{169}$ As the official presence mcreases-for example, where police instruct or direct a private person in conducting a search, ${ }^{170}$ where private security guards are deputized to

requirement. Frank v. Maryland, 359 U.S. 360, 367 (1959). Later, however, the Court reversed itself, finding that even these minor government incursions were "searches" under the fourth amendment and ruling that constitutional requirements-albeit modified by the exigencies of the special circumstances-should apply. See v. City of Seattle, 387 U.S. 541, 545 (1967) (search of private commercial property requires warrant); Camara v. Municipal Court, 387 U.S. 523, 534 (1967) (overruling Frank v. Maryland). But cf. Donovan v. Dewey, 452 U.S. 594 (1981) (federal mine inspections exempt from warrant requirement).

164. Cf. Burton v. Wilmington Parking Auth., 365 U.S. 715, 724 (1961) (where government enjoys a symbiotic relationship with a private entity, government may be hable for private discrimination in the facility).

165. U.S. ConsT. art. II, § 2, cl. 2 (granting the President the power, with the advice and consent of the Senate, to make treaties and to appoint ambassadors, ministers, and consuls).

166. Under an Open Skies agreement, the United States government would have a profound interest in ensuring the success of Soviet and other overflights inside the United States. The government would want these inspections to proceed smoothly and effectively in order to: (a) demonstrate that the United States has scrupulously complied with its imternational obligations; (b) reassure other states that the United States is not undertaking plans for the offensive use of force and those states consequently need not increase their own military activities; and (c) ensure that the United States can credibly insist upon similar cooperation from other states when American aircraft overfly their territories.

167. See Opening Statement by Sergiu Celac, supra note 46 , at 4 (need for a sound cooperative relationship between the inspecting state and the target state).

168. STIMSON CENTER, supra note 37, at 2;

169. See generally $1 \mathrm{w}$. LaFave, Search and Seizure: A Treatise on the Fourth AMENDMENT $\S 1.8$ ( $2 \mathrm{~d}$ ed. 1987) (discussing alternative rnlings on determination of threshold for state action).

170. See Corngold v. United States, 367 F.2d 1, 5-6 (9th Cir. 1966) (where customs agents asked airline employee to open suspicious package and assisted him in doing so, the activity was a 
perform essentially public functions, ${ }^{171}$ or where American law enforceinent officials are deeply involved in the operations of foreign police ${ }^{172}$ courts are more likely to insist upon fourth amendment protections. In the case of Open Skies, the level of official Umited States participation will probably surpass this threshold, rising to the level of a "joint endeavor"173 and triggering intense constitutional scrutiny. The likely outcome, therefore, is that courts will consider Open Skies operations sufficiently governmental in character, purpose, and implementation to mandate full apphication of the fourtli amendment. ${ }^{174}$

\section{Delegation of Sovereign Functions}

Finally, some might attempt to challenge an Open Skies regime

government search); People v. Fierro, 236 Cal. App. 2d 344, 46 Cal. Rptr. 132 (1965) (where motel manager entered defendant's room at the request of sheriff to obtain drug samples, official imvolvement was sufficient to implicate fourth amendment concerns); People v. Barber, 94 Ill. App. 3d 813, 419 N.E.2d 71 (1981) (where police requested that landlord enter defendant's apartment, landlord was acting as government agent im conductimg a search).

171. See Dobyns v. E-Systems, Inc., 667 F.2d 1219, 1223 (5th Cir. 1982) (where private firm contracted with U.S. Government to supply personnel and equipment for military surveillance and peacekeeping, it was performing public function, and fourth amendment applied); People v. Zelinski, 24 Cal. 3d 357, 594 P.2d 1000, 155 Cal. Rptr. 575 (1979) (applying exclusionary rule to ban introduction of evidence seized by private department store personnel who were fulfilling a public function); Alston v. Umited States, 518 A.2d 439 (D.C. 1986) (ordinary department store security officers are not public employees, but if vested with special arrest powers, they perform governmental actions and are subject to the fourth amendment).

172. See United States v. Rosenthal, 793 F.2d 1214, 1231 (11 th Cir. 1986) (fourth amendment is generally mapphicable to searches conducted by foreign sovereign inside its own territory, unless participation of American agents is "so substantial as to convert the activity into a joint venture"), cert. denied, 480 U.S. 919 (1987); Powell v. Zuckert, 366 F.2d 634, 640 (D.C. Cir. 1966) (Air Force officers' search of defendant's home in Japan, pursuant to search warrant issued by Japanese court, was subject to fourth amendment limitations). But cf. United States v. Verdugo-Urquidez, $110 \mathrm{~S}$. Ct. 1056, 1060 (1990) (fourth amendment inapplicable to search by foreign government against its own citizen inside foreign territory, even where American agents participated fully in the search). See generally Annotation, Application of Fourth Amendment Exclusionary Rule to Evidence Obtained Through Search Conducted by Official of Foreign Government, 33 A.L.R. FED. 342 (1977) (reviewing cases in which parties sought to exclude evidence gathered by overseas searches that did not mect fourth amendment standards).

173. See Lustig v. United States, 338 U.S. 74, 79 (1949) ("It is immaterial whether a federal agent originated the idea or joined in it while the search was in progress."); Corngold v. United States, 367 F.2d 1 (9th Cir. 1966) (when a federal agent participates in a joint public/private endeavor, it is a search); Moody v. Umited States, 163 A.2d 337 (D.C. 1960) (where police observed and encouraged private person's search of apartment and received evidence from him, there was a search under the fourth amendment); State v. Becich, 13 Or. App. 415, 509 P.2d 1232 (1973) (where police arranged with private person to observe him removing stolen goods from defendant's home, there was a sufficient government participation in the total enterprise to make it a search). But $c f$. Elkins v. United States, 364 U.S. 206 (1960) (overruling Lustig).

174. See Skinner v. Railway Labor Exeeutives' Ass'n, 489 U.S. 602, 615-16 (1989) (where the federal government "removed all legal barriers" to drug testing of employees by privately owned railroads, and "made plain not only its strong preference for testing, but also its desire to share the fruits of such intrusions," the degree of state action was sufficient to implicate the fourth amendment). 
based upon the assignment of public functions to alien nationals. This issue has sometimes appeared as a major threat to arms control mspection, ${ }^{175}$ as questions lingered regarding the propriety of the exercise of police powers imside the United States by officials who were loyal to another sovereign and not sworn to uphold the Constitution. ${ }^{176}$

The better view, however, based upon judicial acceptance of other forms of delegation ${ }^{177}$ and upon the uncontested practice of foreign imspection under other arms control agreements, ${ }^{178}$ is that Open Skies could survive any such challenge. ${ }^{179}$ The Umited States cannot, of course, delegate to these foreign officials more power than it possesses itself, ${ }^{180}$ but within the constraints of the fourtl amendment, it can assign certain formerly American functions to be performed by Open Skies crews from otler nations.

\section{III \\ CONSTITUTIONALISM AND ARMS CONTROL}

The principles underlying much of the above discussion are that arms control agreements, like all other treaties, are subservient to the Constitution and that no international accord can confer powers or responsibilities that are free from the constraints of the fourth

175. See Kennedy, The Constitution and On-Site Inspection, 14 BrookIYN J. INT'L L. 1, 20-24 (1988).

176. See id.; L. HENKIN, supra note 98, at 55-58, 114-16 (noting the few precedents that suggest that official U..S. powers may be lawfully delegated to foreign or international bodies); see also $D$. ARONOWITZ, supra note 144, at 74, 101-02 (describing how courts are likely to sustain delegation of federal inspection functions). But see Tanzman, supra note 138, at 52-53 (noting that the Supreme Court is unlikely to relinquish to an international panel its power to determine the constitutionality of ad hoc on-site inspections).

177. See Sunshine Coal Co. v. Adkins, 310 U.S. 381 (1940) (upholding delegation of congressional authority to administrative agency and to private industry group for the purpose of setting coal prices); United States v. Rock Royal Coop., Inc., 307 U.S. 533 (1939) (affirming delegation of congressional authority to private trade association for the purpose of establishing parity in milk prices).

178. In the first year of operations under the INF Treaty, the Uinted States conducted 244 onsite inspections at various Soviet nnititary facilities inside Eastern Europe and the Soviet Union. Conversely, the Soviets conducted 96 inspections at American bases in Western Europe and the United States. In addition, each superpower maintained one "permanent" on-site team to inonitor activities full-time at a former missile production plant usside the other country. INF: The First Year, ARMs CONTROL TODAY, Aug. 1989, at 31. See generally Kelmedy, supra note 175, at 20-24 (assessing the question of delegation to Soviet iuspectors of Umited States governmental search powers).

179. But see P. Shane \& H. Bruff, The Law of Presidential Power 85 (1988) ("There may be some life in the delegation doctrine yet."); see also Morrison v. Olson, 487 U.S. 654 (1988) (upholding legislation authorizing judiciary to appoint independent counsel to investigate ethics in government case); Bowsher v. Synar, 478 U.S. 714 (1986) (invalidating Gramm-Rudnan-Hollings deficit control legislation because Congress had purported to delegate to the Comptroller General the executive responsibility for reducing government expenditures).

180. Stimson CENTER, supra note 37, at 2. 
amendment. ${ }^{181}$ This Part briefly summarizes the inchoate tension that Open Skies might reveal between the foreign affairs power and the proteetion of individual rights, especially in the context of the asserted "exception" for national security matters.

The President has a wide range of discretion in managing the nation's foreign affairs. ${ }^{182}$ The traditional balancing of domestic powers among the branches of government gives way when the Umited States confronts other sovereigns, ${ }^{183}$ and courts underscore the importance of enabling the country to "speak with one voice"-necessarily that of the chief executive- in international life. ${ }^{184}$

On the other hand, the courts also jealously protect the rights of the individual. In many instances, the judiciary's insistence upon strict fealty to constitutional procedures has frustrated the executive's fondest desires, even in the area of foreign affairs. ${ }^{185}$ The fourth amendment has proven to be a resilient bulwark against law enforcement excesses, and courts frequently invalidate, or tightly constraim, the search and seizure activities that the executive branch would otherwise employ. ${ }^{186}$

181. See Reid v. Covert, 354 U.S. 1 (1957); Missouri v. Holland, 252 U.S. 416 (1920); RESTATEMENT (THIRD) OF THE FOREIGN RELATIONS LAW OF THE UNITED STATES § 302(2) (1986). But see D. ARONOWITZ, supra note 144, at 19-20 (courts will be reluctant to strike down a treaty, especially one concerning national security, and will give it every presumption of validity).

182. See generally P. Shane \& H. BRUFF, supra note 179, at 507-608 (discussing the scope of presidential powers in foreign policy).

183. RESTATEMENT (THIRD) OF THE FOREIGN RELATIONS LAW OF THE UNITED STATES $\$ 1$ reporter's notes $2 \& 3$ (1986) (the separation of powers in foreign relations is different from that in domestic matters; when dealing with other nations, the President has exceptional powers); $c f . i d$. reporter's note 3 (noting that Justice Jackson's concurrence in Youngstown Sheet \& Tube Co. v. Sawyer, 343 U.S. 579 (1952), is frequently cited in foreign relations cases for the proposition that international affairs is often a "twilight zone" of shared constitutional powers, where either the President or tlie Congress can act).

184. See Chicago \& S. Air Lines v. Waterman S.S. Corp., 333 U.S. 103, 111 (1948) (courts should leave the conduct of foreign policy to the political branclies of government); United States $v$. Curtiss-Wright Export Co., 299 U.S. 304, 319 (1936) (President is the "sole organ of the nation in its external affairs"); United States v. Butenko, 494 F.2d 593, 608 (3d Cir.) (courts should not place limits on the President's powers to discharge responsibilities for foreign affairs), cert. denied, 419 U.S. 881 (1974). The President's powers are not, lowever, unlimited. See Youngstown Sheet \& Tube Co. v. Sawyer, 343 U.S. 579 (1952) (President without power to autliorize seizure of steel mills despite war in Korea); Zweibon v. Mitchell, 516 F.2d 594, 614 (D.C. Cir. 1975) (warrant required even for search under the direction of the President acting in the name of foreign-intelligence gathering for purposes of national security), cert. denied, 425 U.S. 944 (1976).

185. See United States v. Robel, 389 U.S. 258 (1967) (declaring unconstitutional a statute forbidding members of the Communist Party from working in a defense facility); Afroyim v. Rusk, 387 U.S. 253 (1967) (invalidating a statute that stripped United States citizenship from naturalized citizen who voted in foreign political election); Lamont v. Postmaster Gen., 381 U.S. 301 (1965) (declaring unconstitutional a federal statute requiring Postmaster General to detain international mail containing communist propaganda); Faruki v. Rogers, 349 F. Supp. 723 (D.D.C. 1972) (invalidating statute that imposed a ten-year citizenship requirement before a naturalized citizen could jom the Foreign Service).

186. See generally $1 \mathrm{~W}$. LAFAVE, supra note 169, cl. 1 (surveying the listory and current 
Some have asserted that American jurisprudence has developed, or should now develop, a "foreign affairs" or "national security" exception to the usual requirements of the fourth amendment, to permit extraordinary latitude when law enforcement or other federal officials act im furtherance of essential imternational functions. ${ }^{187}$ Arms control might be thought a prototypical setting for this exception, as it can readily be argued that day-to-day concerns about proper police procedures should defer to the exigencies of survival in a hostile global environment. ${ }^{188}$

The Supreme Court has never resolved the uncertainty over whether such an exception exists or what its parameters might be. In fact, in Katz v. United States, ${ }^{189}$ while the Court greatly enlarged the class of cases im which a judicial search warrant would be required for electronic surveillance, it explicitly reserved the question of "[w]lhether safeguards other than prior autliorization by a magistrate would satisfy the Fourth Amendment im a situation involving the national security." 190 This possible distinction sharply divided the Court, with Justice White's concurrence strongly advocating the creation of such a national security exception ${ }^{191}$ and Justice Douglas (joined by Justice Brennan) vigorously opposing it. ${ }^{192}$ The Court in a later case confirmed that "the issue remaims open." 193

operation of the exclusionary rule, which is the leading remedy for violation of the fourth amendment).

187. See J. MoORe, F. Tipson \& R. TURNer, National SecurtTy LaW 1004-14 (1990); Connolly, Warrantless On-Site Inspections for Arms Control Verification: Are They Constitutional?, 24 STAN. J. INT'L. L. 179, $211-23$ (1987); Tanzman, supra note 138, at 41-44; see also Wasserstrom, The Court's Tum Toward a General Reasonableness Interpretation of the Fourth Amendment, 27 AM. CRIM. L. Rev. 119, 127, 129 (1989) (identifying other areas in which the Supreme Court has upheld warrantless searches based upon "special governmental needs").

188. See Turner, supra note 80, at 361-62 ("Civil hbertarians at home and abroad might also object to the potential of [a program similar to Open Skies] to invade individual privacy even inadvertently. There is no way to gainsay such a possibility, but there are unany other unore egregious ineans of intrusion today which we all must hive with, and do... [T] will have to be weighed against the benefits in considering whether or not to proceed in this direction."). Legal scholars have only recently begun to address the constitutional questions presented by the possible application within the United States of the inoderu, intrusive inspection programs that might be included in future arms control treaties. See generally Tanzman, supra note 138 (considering potential fourth amendment infirmities of warrantless searches for verifying compliance with arms control agreements); Kennedy, supra note 175 (same); Comılly, supra note 187 (same).

189. 389 U.S. 347 (1967) (FBI's electronic surveillance outside a public telephone booth requires antecedent judicial authorization).

190. Id. at 358 n.23.

191. Id. at 364 ("We should not require the warrant procedure and the magistrate's judgment if the President of the United States or his chief legal advisor, the Attomey General, has considered the requirements of national security and authorized electronic surveillance as reasonable.").

192. Id. at 359 (arguing that the fourth amendment does not distinguish between different types of crimes in extending protection against unreasonable government intrusions).

193. Giordano v. United States, 394 U.S. 310, 314-15 (1969) (Stewart, J., concurring). The legislative branch, too, has shied away from the issue. In the Omnibus Crime Control and Safe 
The Supreme Court's only other contribution to the consideration of a national security exception to the fourth amendment came in United States v. United States District Court. ${ }^{194}$ There, the government, without a prior search warrant, had wiretapped the telephones of three people suspected of participating in the dynamite bombing of a CIA office in Ann Arbor, Michigan. When the suspects challenged the surveillance, the government asserted a national security exception, arguing that the heightened interest in preserving the integrity and stability of the government itself justified the unusual exercise of power. The Supreme Court, however, focused on the facts that the accused persons were all American nationals, meinbers of an entirely domestic United States orgamization, and that "[t]here was no evidence of any nivolveinent, directly or nidirectly, of a foreign power."195 In this situation of "doinestic security," the Court ruled, the fourth amendnent applies fully and officials nay not dispense with the usual warrant requirements. Agam, however, the Court preserved the possibility of at least a limited national security exception, notmg that it was not then expressing any opinion about cases involving a foreign power or foreign agent. ${ }^{196}$

With this ambivalent guidance, the lower courts have generated a body of divided and ambiguous ease law. In United States v. Truong Dinh Hung, ${ }^{197}$ for example, the Fourth Circuit permitted the FBI to conduct wiretapping and other electromic eavesdropping without a search warrant where the target was suspected of passing classified documents to North Vietnamese diplomats during the Vietnam War. The primary purposes of the surveillance were to acquire "strategic intelligence" and to disrupt the espionage, rather than to compile evidence for a criminal prosecution. ${ }^{198}$ The court determined that the executive's need for "stealth, speed, and secrecy" was especially coinpelling in intelligence operations aimed at foreign powers, and that insistence upon the customary warrant procedure would impermissibly undercut the President's flexibility in combatting the threats presented. ${ }^{199}$ Other circuits have also approved warrantless searches in factually similar situations, where a foreign country or agent assertedly threatened the security of U.S.

Streets Act, 18 U.S.C. $\$ \$ 2510-2520$ (1988), Congress established close regulation over most applications of electronic surveillance, but specified that the new legislation was deliberately crafted so as to avoid altering, or commenting upon in any way, the possible scope of inherent presidential power to engage in warrantless wiretapping for national security purposes. Id. § 2511(3); see also United States v. Umited States Dist. Court, 407 U.S. 297 (1972) (section 2511(3) did not affect presidential power to conduct national security surveillance).

194. 407 U.S. 297 (1972).

195. Id. at 309.

196. Id. at $321 \mathrm{n} .20$.

197. 629 F.2d 908 (4th Cir. 1980), cert denied, 454 U.S. 1144 (1982).

198. Id. at 915 .

199. Id. at 913-14. 


\section{Government operations. ${ }^{200}$}

In Zweibon v. Mitchell, ${ }^{201}$ on the other hand, the D.C. Circuit rejected the warrantless wiretapping of a doinestic organization whose suspected terrorist activities had targeted a foreign country and had thereby threatened to disrupt the conduct of United States foreign policy. ${ }^{202}$ The court determined that even this "foreign connection" did not justify suspending the usual fourth amendment protections applicable to citizens' organizations. ${ }^{203}$ The court concluded that there was no constitutional distinction between warrantless wiretapping undertaken to accunulate foreign intelligence and warrantless wiretapping undertaken in anticipation of criminal prosecution. Indeed, the court came close to asserting that there was no national security exception at all. The holding of the case, however, was niore narrow, asserting that the key inquiry was whether insistence upon a warrant procedure would frustrate the government's purpose for the searcl, and finding that there would be no such frustration in cases involving doniestic organizations. ${ }^{204}$ Other courts confronted witl comparable situations liave also ruled agamst warrantless searches. ${ }^{205}$

Even if a national security exception exists, ${ }^{206}$ however, it would not

200. United States v. Butenko, 494 F.2d 593 (3d Cir.) (no warrant necessary to wiretap Soviet national suspected of conspiring to transmit classified defense information to foreign government, where purpose of surveillance was to acquire strategic intelligence and not to assemble case for criminal prosecution), cert. denied, 419 U.S. 881 (1974); United States v. Brown, 484 F.2d 418, 426 (Sth Cir. 1973) (national security exception permits warrantless wiretapping to gather strategic intelligence), cert. denied, 415 U.S. 960 (1974); United States v. Hoffman, 334 F. Supp. 504 (D.D.C. 1971) (permitting warrantless wiretapping to acquire foreign intelligence, but prohibiting it when aimed at domestic organization).

201. 516 F.2d 594, 602 (D.C. Cir. 1975), cert. denied, 425 U.S. 944 (1976).

202. Zweibon v. Mitchell, 363 F. Supp. 936, 939 (D.D.C. 1973), rev'd, 516 F.2d 594 (D.C. Cir 1975), cert. denied, 425 U.S. 944 (1976). In Zweibon, the Jewish Defense League was accused of engaging in a campaign of terrorist violence against the enibassies and diplonatic personnel of the Soviet Union and various Arab states. The Soviet Union frequently protested to the United States government about these "harassments," and the Attorney General affirmed that the incidents caused the United States embarrassment, could coinplicate American-Soviet relations, and could lead to reprisals against American personnel in Moscow.

203. Zweibon, 516 F.2d at 648-51.

204. Id. at 632 .

205. See, e.g., Berlin Denocratic Club v. Rumsfeld, 410 F. Supp. 144, 156-57 (D.D.C. 1976) (United States officials need search warrant to wiretap American nationals abroad); United States v. Snith, 321 F. Supp. 424, 429 (C.D. Cal. 1971) (judicial warrant is required to wiretap doniestic organizations).

206. The current uncertainty about a constitutional national security exception is likely to persist. Warrantless wiretapping of suspected foreign agents and collaborators-the type of government search that has heretofore generated the nost problematic cases-is now closely regulated by the Foreign Intelligence Surveillance Act, Pub. L. No. 95-511, 92 Stat. 1783 (1978) (codified at 50 U.S.C. $\$ \S 1801-1811$ (1988)). This legislation created a specialized court to consider applications and to issue warrants authorizing electronic surveillance of foreign agents for the purpose of gathering strategic intelligence.

This process has been upheld by the courts, see United States v. Belfield, 692 F.2d 141 (D.C. 
apply to an Open Skies situation. The cases that carve out a dispensation from the usual fourth amendment standards typically do so in special circumstances and with specified limitations that do not correlate with Open Skies proceedings.

For example, one salient thread running through the precedents suggests that a national security exception would apply only where the target of the warrantless observation was a foreign agent or was otherwise acting on behalf of a foreign state. Thus the exceptional search and seizure authority might be justified where the United States government acted to protect itself from a threat posed by a foreign power, but not where the target of the investigation was an American citizen acting without any connection to a foreign entity. ${ }^{207}$ Open Skies, however, presents precisely this latter scenario: the observations would be performed by a foreign power, and they would be observations of United States nationals. Where the Open Skies monitoring detects ordinary Americans acting in the course of their everyday, "non-international" hives, even a broadly drawn national security exception would be iniapphicable.

Similarly, the sparse case law suggests other important constraints apphicable to any national security exception. For example, the exception apphies only where the purpose of the extraordinary search mechamism is to acquire "strategic intelligence" useful to the chief executive in dealing with threats from potentially hostile foreign states; ${ }^{208}$ it applies

Cir. 1982); United States v. Megahey, 553 F. Supp. 1180 (E.D.N.Y. 1982), aff'd, 729 F.2d 1444 (2d Cir. 1983); J. CarR, The LaW of Electronic Surveillance § 9.3(c) (2d ed. 1986 \& Supp. 1989), and seems to be working satisfactorily. Consequently, relatively fewer cases night arise in the future to test the general concept of a national security exception to the fourth amendnient or to defiue its parameters. See P. Shane \& H. BRUFF, supra uote 179, at 497-506; see also J. MOORE, F. TIPSON \& R. TURNER, supra note 187, at 1018-26 (in cases where foreign intelligence is at stake and the U.S. government is pitted against other governments, the definition of rcasonable behavior is different from that used in ordinary criminal cases). But see Lardner, Intelligence Panel's Secrecy Criticized, Wash. Post, Aug. 1, 1990, at A17, col. 1 (reviewing legislative proposals to amend Foreign Intelligence Surveillance Act to regulate searches in national security cases).

207. See United States v. Truong Dinh Hung, 629 F.2d 908 (4th Cir. 1980) (discussed at supra text accompanying notes 197-99), cert. denied, 454 U.S. 1144 (1982); Zweibon v. Mitchell, 516 F.2d 594 (D.C. Cir. 1975) (discussed at supra text accompanying notes 201-04), cert. denied, 425 U.S. 944 (1976); United States v. Butenko, 494 F.2d 593 (3d Cir.) (discussed at supra note 200), cert. denied. 419 U.S. 881 (1974); United States v. Hoffinan, 334 F. Supp. 504 (D.D.C. 1971) (discussed at supra note 200 ).

208. See, e.g., Truong Dinh Hung, 629 F.2d at 913-14 (need for executive flexibility in areas of foreign intelligence surveillance renders warrant requirenient inpractical); United States v. Brown, 484 F.2d 418, 426 (5th Cir. 1973) (President nuay, by virtue of his inherent power to protect national seeurity, constitutionally authorize warrantless wiretaps for the purpose of gathering foreign intelligence), cert. denied, 415 U.S. 960 (1974); United States v. Clay, 430 F.2d 165, 171-72 (5th Cir. 1970) (recognizing constitutional and statutory soundness of ordering wiretap surveillance to obtain foreign intelligence), rev'd on other grounds, 403 U.S. 698 (1971); Hoffman, 334 F. Supp. at 507 (President niay possess imphed constitutional authority to conduct warrantless searches where necessary in the conduct of foreign affairs). But see Zweibon, 516 F.2d at 614 (warrant required to 
only in exigent circuinstances, where special powers are essential; ${ }^{209}$ it is subject to a general "minimization" requirement, confining the warrantless activity to the lowest level possible; ${ }^{210}$ it has heretofore been utilized exclusively in the unique context of wiretapping, and has had no important applications to otlier forms of search and seizure; ${ }^{211}$ and the authority to invoke the exception has been attributed solely to the President and the Attorney General, who may not delegate it to lower-ranking officials. $^{212}$

Open Skies, lowever, would depart from all these standards. It would entail warrantless observation of the activities of ordinary Americans and would acquire information unrelated to strategic intelligence concerns about foreign agents or countries. States would conduct their Open Skies observation on a routme, nonenuergency basis, and on a grand scale instead of a minimal one. It would involve reinote sensing by optical and other means, rather than wiretapping. The targets of the observation would by selected by foreign nationals assisted by Americans in relatively junior positions in the bureaucracy. Thus, Open Skies could not fall within any national security exception, even if courts were to recognize such an exception in other contexts.

As important as the Open Skies agreement may be, therefore, it would have to yield to the fourtli amendment's limitations on searclies and seizures, and it would be subject to the established constraints on government imvestigatory techniques. The government may lawfully undertake even its critical international functions ouly wlien they are consistent with the Constitution. The balance between foreign policy goals and donuestic liberties renuains, even when national security interests are at stake. ${ }^{213}$

install wiretap on domestic organization that is neither an agent of, nor acting in collaboration with, a foreign power).

209. See, e.g., Truong Dinh Hung, 629 F.2d at 916 (underscoring the limited nature of the foreign intelligence exception); Halperin v. Kissinger, 606 F.2d 1192, 1200-01 (D.C. Cir. 1979) (special powers of the executive must be limited to instances of immediate and grave peril to the nation), aff'd in part, cert. dismissed in part, 452 U.S. 713 (1981); Slimyu Noro v. United States, 148 F.2d 696, 698-99 (5th Cir.) (warrantless search allowed under the urgent circumstances and sudden emergency of war), cert. denied, 326 U.S. 720 (1945).

210. See, e.g., Truong Dinh Hung, 629 F.2d at 915; Halperin, 606 F.2d at 1200-01; Shinyu Noro. 148 F.2d at 698.

211. See United States v. Ehrlichman, 376 F. Supp. 29, 33 (D.D.C. 1974) (intelligence exception limited to issues of wiretapping, which is cousidered a "relatively noirintrusive search"), aff"d, 546 F.2d 910, 933 (D.C. Cir. 1976), cert. denied, 429 U.S. 1120 (1977). But see United States v. Smith, 321 F. Supp. 424, 429 (C.D. Cal. 1971) (suggesting that electronic surveillance is the inost objectionable of all searches because it is carried out against an unsuspecting individual).

212. Umited States v. Ehrlichınan, 546 F.2d 910, 925 (D.C. Cir. 1976), cert. denied, 429 U.S. 1120 (1977).

213. See Smith, 321 F. Supp. at 430 ("The Constitution ... was written so as to strike a balance between the protection of political freedom and protection of national security interests. To guarantee political freedom, our forefathers agreed to take certain risks which are inherent in a free 
IV

\section{Is Open Skies a "SeArch"?: Precedents}

The central question concerning the constitutionality of Open Skies is whether the functioning of Open Skies aircraft constitutes a "search" of constitutional proportions, triggering the full panoply of fourth amendment protections. This question is critical because if Open Skies is deemed a search, it is probably illegal and the treaty regime incorporating it will fail. ${ }^{214}$

The question arises in this stark form because of the nature of the Open Skies inspection regime itself. The treaty would contemplate no procedure for obtaining a search warrant prior to the overflight. Indeed, an essential aspect of the "anytime, anyplace" character of the arrangement would be the explicit rejection of any need for local authorities to approve an inspector's search. ${ }^{215}$ The Supreme Court, however, has declared that warrantless searches are "per se unreasonable under the Fourth Amendment, subject only to a few specifically estabhished and well-defined exceptions."216

While some of these exceptions, such as "pervasively regulated

democracy. It is unthinkable that we should now be required to sacrifice those freedoms in order to defend them.").

214. Cf. Dow Chen. Co. v. United States, 749 F.2d 307, 311 (6th Cir. 1984) (if aerial surveillance of chemical facility is deemed a search for constitutional purposes, it violates the fourth amendment; if it is not a search, law enforcement officials may proceed without warrant), aff'd, 476 U.S. 227 (1986).

215. Under an Open Skies treaty, the Umited States would not depend upon the tolerance of a court of, for example, the Soviet Union in order to conduct an overflight. This arrangement would be necessary for U.S. interests, as the United States would not want to submit its flight plan for review and approval, even in camera, where the dangers of delay, dispruption, or denial might arise. Under the symmetry inposed by an Open Skies treaty, however, the United States would not be able to msist that other states apply for search warrants from American courts to authorize Open Skies overflights in this country.

216. Katz v. United States, 389 U.S. 347, 357 (1967). But see Amsterdam, Perspectives on the Fourth Amendment, 58 MiNN. L. REV. 349, 375 (1974) (categories of exceptions to the warrant requirement have proliferated); Gildea \& Weiler, Unreasonable Searches and Seizures, 26 AM. CR1M. L. REV. 1397 app. at 1428-32 (1989) (summarizing post-Katz exceptions to the warrant requirement). 
industries,"217 "administrative searches,"218 and international border incidents, ${ }^{219}$ may apply to certain aspects of Open Skies, they do not provide blanket permission for warrantless aerial observation. ${ }^{220}$ In order

217. Some industries (such as mining, food preparation, distilleries, and firearms manufacturing), in which the historical pattern of government oversight and inspection is especially thorough, are deemed to possess a diminished expectation of privacy, and extraordinary government intrusions are therefore constitutionally tolerable. See Donovan v. Dewey, 452 U.S. 594, 598 (1981) (recognizing greater latitude to conduct warrantless searches of commercial property because the privacy interest is not the same as im private homes); Marshall v. Barlow's, Inc., 436 U.S. 307, 313 14 (1978) (recognizing an exception to search warrant requirement for "closely regulated" industries traditionally subject to inspection and scrutiny); Umited States v. Biswell, 406 U.S. 311, 315 (1972) (warrantless search allowed in the context of a system for the regulatory inspection of business premises, dictated by statute and limited in time, place, and scope).

This exception might permit arms control inspectors the latitude to enter and imspect selected types of business facilities, but would not provide legal justification for invasive inomitoring of American homes and ordinary commercial establishments. See Connolly, supra note 187, at 200-11 (warrantless inspections already authorized by statute for such "pervasively regulated" industries as nuclear facilities, common carriers, producers of certain biological agents, electromes, and air carriers); Tanzman, supra note 138 , at $44-48$ (pervasively regulated industry exception to fourth amendment warrant requirement provides leeway in some commercial inspeetions, whereas other businesses and private homes receive inore constitutional protection).

218. Administrative searches include a variety of inspections undertaken by local authorities to inomitor comphance with such regulations as housing codes, zoning rules, and health and safety regulations. The relatively minor, non-punitive nature of these inquiries has resulted in a relaxed warrant procedure, but the fourth amendinent remains relevant. See See v. City of Seattle, 387 U.S. 541, 545 (1967) (suitable warrant procedure required by fourth amendment to enter and inspect private commercial premises without consent); Camara v. Municipal Court, 387 U.S. 523, 34 (1967) (administrative searches premised on noneinergency housing code violations represent a significant intrusion upon interests protected by the fourth amendment). The district court in Dow Chemical Co. v. United States, 536 F. Supp. 1355, 1359 (E.D. Mich. 1982), rev'd, 749 F.2d 307 (6th Cir. 1984), aff'd, 476 U.S. 227 (1986), concluded that legal analysis of aerial overflight and photography "roughly" fits into the category of administrative searches, but the higher courts did not pursue that approach. Arms control inspectors might shelter some of their activities under this rubric, but it will not justify all the activities of Open Skies. See Koplow, Arms Control Inspection: Constitutional Restrictions on Treaty Verification in the United States, 63 N.Y.U. L. REV. 229, $305-08$ (1988) (arguing that Camara and See created an unprecedented apparatns for authorizing administrative search warrants, which departs from individuated probable cause analysis); see also Kennedy, supra note 175, at 7-9 ("probable canse" showing for issung a warrant to conduct an administrative search is less onerous than the showing generally required in a criminal context).

219. Law enforcement authorities are accorded exceptional powers to deal with persons or objects crossing a border into the United States. See United States v. Ramsey, 431 U.S. 606, 616 (1977) (border searches are per se reasonable, given the country's need to protect itself, and fourth amendment does not apply); United States v. Weil, 432 F.2d 1320, 1323 (9th Cir. 1970) (upholding warrantless search of items found near the border, even if unknown whether items crossed the border recently); Alexander v. United States, 362 F.2d 379, 382 (9th Cir. 1966) (warrantless search of vehicle in interior of country justified because vehicle had recently crossed the border and had been under constant surveillance). While this extraordimary category of powers may be relevant to some applicatious of arms control verification, it will cover only a small portion of future Open Shies operations.

220. During most Open Skies observations, the targets being overflown will not notice or care that they are being monitored. Conceivably, such disregard could be construed as implied consent, and consent of the searched individual can provide a legal justification for a warrantless search. See Schneckloth v. Bustamonte, 412 U.S. 218 (1973); W. RINGEL, SEARCHES \& SE1zURES, ARRESTS \& Convictions $\S \S 9.1-9.2$ (1985); see also Tanzman, supra note 138 , at 58-62 (discussing the 
for the Open Skies arrangement to be constitutional, therefore, its investigative activities must not rise to the level of a fourth amendment search.

The decision in Katz v. United States ${ }^{221}$ still provides the leading definition of a search. The court there determined that the fourth amendment does not protect what a person "knowingly exposes to the public," but it does protect what he or she "seeks to preserve as private."222 Justice Harlan's concurring opinion elaborated this distinction, establishing a two-part test for the coverage of the fourth amendment: First, has the person exhibited an actual expectation of privacy? Second, is that expectation one that society is prepared to accept as reasonable? $?^{223}$

The Court has thus directed attention to whether a person has voluntarily accepted the risk of being seen or heard, ${ }^{224}$ and it has eschewed the earlier focus on the narrow question of whether the government obtamed its data through a physical trespass. ${ }^{225}$ Where a person conducts activities in "plam view" of the general public and allows anyone passing by to notice his or her activities, no lingering expectation of privacy remains and the government may observe without a warrant the activities that anyone else could also observe. Conversely, where the person has actually and reasonably withdrawn from public scrutimy, the government may not probe further without conducting a search and extending the protections of the fourth amendment. ${ }^{226}$

The application of these principles to cases involving aerial overflight has proven especially vexatious. Pohice or other law enforcement officers often seek to conduct aerial surveillance of someone's backyard, farm, or busimess in order to locate or identify illegal activities, ${ }^{227}$ some-

possibility of requiring contractors to provide contractual consent to inspection prior to entering into a contract with the federal government).

221. 389 U.S. 347 (1967).

222. Id. at 351.

223. Id. at 361 .

224. See Oliver v. Uuited States, 466 U.S. 170, 179 (1984) (fourth amendment protection of reasonable expectation of privacy does not apply to activities undertaken in open fields).

225. See Katz, 389 U.S. at 353 (rejecting the almost exclusive focus on the question of physical invasion of a protected space- the standard that had prevailed under Olmstead v. United States, 277 U.S. 438 (1928)).

226. But see Smith v. Maryland, 442 U.S. 735, 745-46 (1979) (warrantless use of pen register simply to record the teleplone numbers dialed from a particular telephone is not a search, since it acquires only information that is routinely exposed to the telephone company without accessing the contents of the conversation).

227. It is noteworthy that, in some instances, state law enforcement officials have utilized U-2 aircraft-originally dedicated to collecting covert intelligence against other countries for national security purposes-to assist in the process of aerial surveillance to locate, identify, and photograph marijuana plantations in California as part of a criminal investigation. See National Org. for Reform of Marijuana Laws v. Mullen, 608 F. Supp. 945 (C.D. Cal. 1985). In at least one other instance, the government used NASA satelite photography to assist a law enforcement prosecution, during a 1978 enforcement action against Reserve Mining Company for dumping taconite tailings into Lake Superior. United States v. Reserve Mining Co., 380 F. Supp. 11, 39 n.29 (D. Minn. 1974), 
times without first obtaining a judicial search warrant. ${ }^{228}$ For years, this practice sharply divided the lower courts, not only with regard to the legitimacy of the warrantless sightings, but also with regard to the appropriate inethodology and factors to consider in evaluating the pohice conduct. ${ }^{229}$

In 1986, the companion cases of California v. Ciraolo ${ }^{230}$ and Dow Chemical Co. v. United States, ${ }^{231}$ both decided in the Supreine Court by five-to-four votes, provided a substantial ineasure of guidance ${ }^{232}$ in a fashion that would permit, but place limits on, the exercise of Open Skies inspections. In Ciraolo, local police officials received an anonyınous telephone tip that the accused was growing inarijuana plants in his backyard. As that information alone was insufficient to obtain a search warrant, and as the configuration and fencing of the property in question

modified, Reserve Mining Co. v. EPA, 514 F.2d 492 (8th Cir. 1976); Tell, Suits Sight Spies in the Sky, 3 NAT'L L.J., Dec. 15, 1980, at 1, 28.

228. The less problematic surveillance cases are those in which officers on the ground, in a public place, or in a place the public has a right to be, observe activities (such as a smoke plume emanating froin a factory) that anyone else could also have observed. In such instances, the target of the observation has done nothing to prevent inonitoring by police or by anyone else, and courts have found no expectation of privacy. See, eg., Air Pollution Variance Bd. v. Western Alfalfa Corp., 416 U.S. 861 (1974) (inspector's entry onto corporation's land was not a search, as long as the public at large was not excluded from that space, and the inspector merely saw what anyone else could have seen).

229. Compare United States v. Allen, 633 F.2d 1282 (9th Cir.), amended, 675 F.2d 1373 (9th Cir. 1980), cert. denied, 454 U.S. 833 (1981); and Uunted States v. DeBacker, 493 F. Supp. 1078 (W.D. Mich. 1980); and Dean v. Superior Court, 35 Cal. App. 3d 112, 110 Cal. Rptr. 585 (1973); and Randall v. State, 458 So. 2d 822 (Fla. Dist. Ct. App. 1985); and United States v. Knight, 63 Haw. 90, 621 P.2d 370 (1980); and State v. Stachler, 58 Haw. 412, 570 P.2d 1323 (1977); and State v. Ryder, 315 N.W.2d 786 (Iowa 1982); and State v. Myrick, 102 Wash. 2d 506, 688 P.2d 151 (1984) (en banc) (all upholding warrantless aerial surveillance) with United States v. Mullinex, 508 F. Supp. 512 (E.D. Ky. 1980); and People v. Sabo, 185 Cal. App. 3d 845, 230 Cal. Rptr. 170 (1986), cert. denied, 481 U.S. 1058 (1987); and Commonwealth v. Oghialoro, 377 Pa. Super. 317, 547 A.2d 387 (1988), aff'd, 579 A.2d 1288 (1990) (all invalidating warrantless aerial searches). See also Note, Warrantless Aerial Surveillance: A Constitutional Analysis, 35 VAND. L. REv. 409, 416 (1982) (majority of courts agree that warrantless aerial surveillance is constitutional, but courts are divided over whether to employ an "open fields," "open view," or "no reasonable expeetation of privacy" rationale); Note, The Fourth Amendment in the Age of Aerial Surveillance: Curtains for the Curtilage?, 60 N.Y.U. L. REv. 725, 726 (1985) (courts disagree about the appropriate analytical framework for determining the constitutionality of warrantless aerial surveillance).

230. 476 U.S. 207 (1986).

231. 476 U.S. 227 (1986).

232. See United States v. Bassford, 812 F.2d 16, $18-19$ (1st Cir.) (deeision in Ciraolo, issued after briefs were filed on Bassford's appeal, controlled the case and validated warrantless aerial surveillance of defendant's marijuana farm), cert denied, 481 U.S. 1022 (1987); United States v. Broadhurst, 805 F.2d 849 (9th Cir. 1986) (warrantless overflight was not a search because no reasonable expectation of privacy). But see People v. Sabo, 185 Cal. App. 3d 845, 853, $230 \mathrm{Cal}$. Rptr. 170, 175 (1986) (holding that Ciraolo does not declare a rule governing aerial surveillance in all circumstances, at any altitude, from any platform), cert. denied, 481 U.S. 1058 (1987); Commonwealth v. Oglialoro, 377 Pa. Super. 317, 325-26, 547 A.2d 387, 391 (1988) (explaining that Ciraolo validates ouly those naked-eye observations made from a helicopter hovering within navigable airspace), aff'd, 579 A.2d 1288 (1990). 
prevented ground-level observation of the backyard, the police decided to conduct a warrantless aerial surveillance. Two officers trained in marijuana identification accordingly hired a private plane and flew over the property within navigable airspace at an altitude of 1000 feet. They identified the contraband plants and photographed thein with a standard thirty-five millimeter camera. Based on these facts, the officers later obtained a search warrant and seized seventy-three marijuana plants. ${ }^{233}$

The defendant was then tried on charges of marijuana cultivation. When the trial court denied his motion to suppress the evidence froin the search, he pled guilty. The California Court of Appeal reversed the suppression ruling, finding that the warrantless overflight was a search of constitutional proportions because the defendant had held a reasonable expectation of privacy in the shelter of his backyard. ${ }^{234}$ The United States Supreme Court reversed this decision on the ground that, although the defendant satisfied the first prong of the Katz test, since he had a subjective expectation of privacy based upon the opaque fencing, ${ }^{235}$ he did not satisfy the second Katz criterion. The Court focused on the frequency of aerial overflights conducted by all sorts of people for all sorts of purposes, indicating that any private person could easily have observed Ciraolo's backyard from above. ${ }^{236}$ In those circumstances, it was simply unreasonable for him not to anticipate overflight. ${ }^{237}$ It was therefore not a search for the local police to use the saine type of monitoring capabilities available to private citizens generally. ${ }^{238}$

233. Ciraolo, 476 U.S. at 209-10.

234. People v. Ciraolo, 161 Cal. App. 3d 1081, 1090, 208 Cal. Rptr. 93, $97-98$ (1984), rev'd, 476 U.S. 207 (1986).

235. Ciraolo, 476 U.S. at 211. The majority conceded only that through the erection of the fencing, the defendant had manifested an expectation of privacy against "normal sidewalk traffic." The inajority raised, but did not answer, the question of whether the ten-foot-high fence precluded warrantless observation by police officers who were "perched on the top of a truck or a 2-level bus" from which they could pecr over the fence into the backyard. Id. The dissenters argued, however, that under well-establisled precedents, the defendant had fully inet the first Katz test, and "the Court would certainly agree that [the poliee officer] would have conducted an unreasonable search had he climbed over the fence, or used a ladder to peer into the yard without first securing a warrant." Id. at 222-23 (Powell, J., dissenting); see also United States v. McMillon, 350 F. Supp. 593, 597 (D.D.C. 1972) (not a search for police to look over defendant's fence and into his backyard while standing on the porcl of a cooperating neighbor); George v. State, 509 S.W.2d 347, 348 (Tex. Crim. App. 1974) (not a search to pecr through minute cracks and knotholes in high fence).

236. Ciraolo, 476 U.S. at 213-14.

237. Id. at 212-13. The Court agrced with the defendant that the backyard was within the "curtilage" of the lome, the area immediately surrounding the dwelling and sharing inany of the traditional protections accorded to the inost intinate private spaces. The Court nonetheless concluded that open-air activities conducted in the backyard were voluntarily exposed to overhead viewings. But see id. at 222 n.7 (Powell, J., dissenting) (majority failed to mention that in addition to the marijuana garden, Ciraolo's backyard included a small swinnining pool and sun deck used for sunbathing and other private activities closely associated with the home).

238. See id. at 213-14. The dissenting opinion, written by Justice Powell and joined by Justices Brennan, Marsliall, and Blackmun, contended that the majority had not been faithful to the Katz 
In Dow, the Court extended the authorization for warrantless overflights to industrial operations, a context particularly relevant to Open Skies. At the same time, the Court included an important caveat about the very types of high-technology sensing that Open Skies inonitors might adopt. In 1978, the Environmental Protection Agency wanted to inspect the emissions froin two coal-fired power plants located inside Dow's 2000-acre chemical inanufacturing facility at Midland, Michigan. ${ }^{239}$ Dow refused voluntary entry, ${ }^{240}$ and its elaborate security procedures effectively precluded adequate observation froin ground level. ${ }^{241}$ Undaunted, the EPA hired a commercial airplane to overfly the facility and take photographs. ${ }^{242}$ The airplane made six low-altitude passes over the coinplex and acquired seventy-five color photographs of various portions of the installation and equipınent, using a $\$ 22,000$ floor-1nounted Wild RC-10 inapping camera described as "the finest precision aerial camera available." 243 The resulting imagery revealed "a great deal more than the human eye could ever see":244 a resolution of one inch to twenty feet or better, with no loss of detail, displaying itenis such as pipes and power lines as snall as one-half inch in diameter. ${ }^{245}$

Dow challenged the EPA action as, inter alia, an illegal search. ${ }^{246}$ The federal district court ruled in favor of Dow, finding that the coinpany's security apparatus had created a subjective expectation of privacy, and that general societal support for the protection of trade secrets from

tests. The dissenters argued that the majority's rationale was simply that members of the general public engage in air traffic and might look down and see something. This fact, however, did not explain why the opportunity for such fleeting and casual observation should so completely destroy the landowner's reasonable expectation of privacy. Even if everyone must accept that public use of the navigable airspace may result in occasional overfights, this modern reality should not automatically afford police the unencumbered right to conduct dedicated overflights of such focused intensity. See id. at 222-24 (Powell, J., dissenting).

239. Dow Chein. Co. v. United States, 476 U.S. 227, 229 (1986).

240. Id.

241. Id. Dow allocated $\$ 3.25$ million annually to provide seeurity for its facility, and the physical mcasures included a chain link fence, a closed-circuit television mouitoring systen, alarm systems, notion detectors, roving patrols, and close haison with local law enforcement officials. Dow Chem. Co. v. United States, 536 F. Supp. 1355, 1364-65 (E.D. Mich. 1982), rev'd, 749 F.2d 307 (6th Cir. 1984), aff'd, 476 U.S. 227 (1986).

242. Dow, 476 U.S. at 229. The Environmental Protection Agency has also reportedly obtained high-resolution photography of American conmercial facilities directly from the national security community, which operates aerial and satellite photo-reconnaissance programs inside the United States for training purposes. Sloan, Big Brother Strikes Again, FoRBES, May 12, 1980, at 50.

243. Dow, 536 F. Supp. at 1357 \& n.2. The plane made repeat passes at 12,000, 3000, and 1200 feet. Id. At all times, it was within legal navigable airspace. Dow, 476 U.S. at 229.

244. Dow, 536 F. Supp. at 1367.

245. Id. at 1357.

246. Id. at 1358. Dow also argued that the EPA action was a taking of property (trade secrets) without due process of law in violation of the fifth amendment, and asserted that the agency had exceeded its statutory authority by using warrantless aerial surveillance instead of judicially approved investigatory techniques. Id. 
coinpetitors' airborne snooping indicated that society considered this expectation "reasonable." ${ }^{247}$ The Sixth Circuit reversed, limiting Dow's expectation of privacy to only the specific type of intrusion against which it had protected itself (i.e., ground-level observation) and finding that Dow had voluntarily assumed the risk of exposing itself to overhead observation. ${ }^{248}$

The Supreme Court also concluded that no search had occurred, since " '[w]hat is observable by the public is observable without a warrant, by the Government imspector as well." "249 Although Dow did not necessarily have to undertake the absurdly expensive alteruative of erecting an opaque shield over its entire facility, ${ }^{250}$ it could not claim an expectation of privacy where it had tacitly decided to expose portions of its operations to plain overhead view. ${ }^{251}$

In downplaying the quality of the EPA photography and the inti1nacy of detail it presented, ${ }^{252}$ the Court contrasted this type of "ordinary" technology with more advanced hypothetical kinds of intrusionsthe sorts of inspections that Open Skies might prescribe:

[S]urveillance of private property by using highly sophisticated surveillance equipment not generally available to the public, such as satellite

247. Id. at $1365-67$.

248. Dow Chem. Co. v. Umited States, 749 F.2d 307, 313 (6th Cir 1984), aff'd, 476 U.S. 227 (1986).

249. Dow, 476 U.S. at 238 (quotimg Marshall v. Barlow's, Inc., 436 U.S. 307, 315 (1978)). Dow had conceded that an overflight relying solely upon observation by the naked eye-like ordinary observation from a nearby hillside-would not be a search. Id. at 234; see United States v. Allen, 675 F.2d 1373, 1381 (9th Cir. 1980) (surveillance with binoculars from hill overlooking ranch was not a search), cert. denied, 454 U.S. 833 (1981).

250. Dow, 476 U.S. at 236. The open-air design of the plant stemmed partly from safety considerations. In addition, constructing a roof over just one part of the facility would have cost some \$15 million. Id. at $240 \mathrm{n} .1$ (Powell, J., concurring in part and dissenting in part).

251. See id. at 237-39. Much of the Court's opinion considered whether the facility could appropriately be characterized as constituting an "industrial curtilage" with special protections, comparable to those accorded to the area surrounding a dwelling. The Court determined that the factory fell somewhere between "open fields" and curtilage. Id. at 235-36.

The dissenters in Dow argued vigorously that the majority decision was inconsistent with Katz and "may sigual a significant retreat from the rationale of prior Fourth Amendment decisions." Id. at 244 (Powell, J., concurring in part and dissenting in part). The dissent contended that Dow had done everything plausible to remove itself from observation, and that society should require no greater degree of self-proteetion. Dow had in fact undertaken several programs to protect its facility from unwanted aerial observation. The company monitored overflights, attempted to contact airplanes engaged in "suspicious" behavior, and tried to dissuade photographers from utilizing pictures that might reveal confidential information. Id. at 241-42.

252. See id. at 238. The Court stated that "[t]he photographs at issue in this case are essentially like those commonly used in mapmaking. Any person with an airplane and an aerial camera could readily duplicate them." Id. at 231 . The Court also noted that although power lines as sinall as onehalf inch in diameter were revealed on the photographs, these items were observable only because of their great length and their high contrast with the snow-white background. Other objects of a similar diameter, such as a class ring, were not visible, and the resolution of the photography was insufficient to identify individual persons or to reveal the contents of docuinents. Id. at 238 n.5. 
technology, might be constitutionally proscribed absent a warrant. But the photographs here are not so revealing of intimate details as to raise constitutional concerns. Although they undoubtedly give EPA more detailed information than naked-eye views, they remain limited to an outline of the facility's buildings and equipment. The mere fact that human vision is enhanced somewhat, at least to the degree here, does not give rise to constitutional problems. An electromic device to penetrate walls or windows so as to hear and record confidential discussions of chemical formulae or other trade secrets would raise very different and far more serious questions; other protections such as trade secret laws are available to protect commercial activities from private surveillance by competitors. $^{253}$

The Dow Court thus aligned itself with, but did not cite, an earlier line of cases regarding police "enhancement" of ordinary liuman senses. These precedents estabhshed that in a "plain view" situation, law enforcement" officers could freely look, histen, and sinell witliout converting their observation into a search, ${ }^{254}$ and that tliey could also enhance tlieir ordinary human powers of perception to soine extent through the use of inodest inechanical or other means sucli as flashlights, binoculars, or trained dogs. ${ }^{255}$ More substantial enhanceinent, however, such as that provided by a high-resolution miglit-vision telescope (whicli provides an image no longer within the officer's "plain view"), transforms the inspection activity into a warrantless and presumptively illegal search. ${ }^{256}$

253. Id. at $238-39$ (footnote omitted). In Ciraolo, the Court also noted that the state had conceded that aerial observation "may become invasive, either due to physical intrusiveness or through modern technology which discloses to the senses those intinate associations, objects or activities otherwise imperceptible to police or fellow citizens." California v. Ciraolo, 476 U.S. 207, 215 n.3 (1986).

254. See State v. Dickerson, 313 N.W.2d 526, 533 (Iowa 1981) (police may look through window of door to defendant's lome, plotograpl items inside, and enlarge photographs without warrant); State v. Powell, 99 N.M. 381, 385, 658 P.2d 456, 459 (N.M. Ct. App. 1983) (approving police officer's looking through window of pickup truck even witliout warrant); State v. Planz, 304 N.W.2d 74, 80 (N.D. 1981) (not a search for police to look through window of parked car); 1 W. LAFAVE, supra note $169, \$ 2.2$, at 245.

255. See United States v. Lace, 669 F.2d 46 (2d Cir. 1982) (approving use of binoculars, telescope, and other vision-enhancing devices to scrutinize open areas of defendant's land); Umited States v. Allen, 675 F.2d 1373, 1381 (9th Cir. 1980) (placement of seismometers to momitor velicle traffic into and out of defendant's ranch could raise complex questions), cert. denied, 454 U.S. 833 (1981); United States v. Dubrofsky, 581 F.2d 208, 211 (9th Cir. 1978) (pernissible without warrant to nse "beeper" for covert trailing of a suspect); United States v. Moore, 562 F.2d 106 (1st Cir. 1977) (police pernitted to use beeper witlout warrant to assist in momitoring the location of a package while it was being transported upon public highways, but not when it was inside a lome), cert. denied, 435 U.S. 926 (1978); United States v. Wright, 449 F.2d 1355, 1357 (D.C. Cir. 1971) (approving warrantless use of flashlight to look into garage through gap in garage doors), cert. denied, 405 U.S. 947 (1972); State v. Denton, 387 So. 2d 578, 583-84 (La. 1980) (approving officers' use of "night scope" to observe defendant's activities conducted in darkness on public pier 100 feet away).

256. See United States v. Taborda, 635 F.2d 131, 138 (2d Cir. 1980) (observation by naked eye of activities conducted inside defendant's apartment was not a search, but use of vision-enhancing 
Three years later, in Florida v. Riley, ${ }^{257}$ the Supreme Court revisited the question of warrantless overhead reconnaissance and reinforced its earlier lioldings. In Riley, another anonyinous tip had alerted a county sheriff that the accused was growing inarijuana in a greenliouse at the back of his property. Again, enclosures and vegetation precluded terrestrial observation. This time, the investigating officer used a helicopter to obtain a better vantage point, circling the property twice at an altitude of only 400 feet and peering through holes in the greenhouse left by some missing roofing panels. ${ }^{258}$

When the defendant was charged with marijuana possession, the state trial court suppressed the evidence from the searcli. The Florida Court of Appeals reversed that judgment, and the Florida Supreme Court then reversed the appellate decision. The Uirited States Supreme Court, too, reversed the court below it, and decided not to suppress the evidence, finding that, consistent witl Ciraolo, tliere had been no search. $^{259}$

A four-Justice plurality ${ }^{260}$ determined that while Riley no doubt intended and hoped for privacy in his greenhouse, society was not prepared to accept that claim as reasonable, because the holes in the greenhouse inade its contents visible to the flying pubhic. ${ }^{261}$ There was no constitutional distinction between observation by hehcopter and observation by fixed-wing aircraft, since no evidence suggested that helicopter overflights were unusual in that part of the country. ${ }^{262}$ The plurality also stressed that although the helicopter was flying at lower than the mini-

telescope to detect itenıs not otherwise visible was a search); United States v. Kim, 415 F. Supp. 1252, 1258 (D. Haw. 1976) (warrantless use of $800 \mathrm{~mm}$ telescope to look inside defendant's apartment from a quarter of a mile away violated fourth amendment); People v. Amo, 90 Cal. App. 3d 505, 512, 153 Cal.Rptr. 624, 628 (1979) (use of binoculars to see through window into office building is a search where naked eye would not be able to see inside at all); State v. Knight, 63 Haw. 90, 93, 621 P.2d 370, 373 (1980) (use of binoculars to see marijuana inside greenhouse from 100 yards away is a search); Commonwealth v. Williams, $494 \mathrm{~Pa} .496,500,431 \mathrm{A.2d} 964,966$ (1981) (disapproving warrantless use of "startron" device that enabled poliee to view, from across the street, activities inside apartment in the dark); see also 1 LAFAvE, supra note $169, \S 2.2$ (d), at 347-55 (discussing the difficulty of assessing the warrantless use of devices such as magnetometers, $X$-ray scanners, and ultraviolet lights); Warrantless Aerial Surveillance, supra note 229, at 426 (describing courts' attitudes toward technologically enhanced surveillance). See generally, Granberg, Is Warrantless Aerial Surveillance Constitutional, CAL. ST. B.J., Nov. 1980, at 451-54 (same).

257. 488 U.S. 445 (1989).

258. Id. at 448 .

259. Id. at 449.

260. The judgment of the Court was prepared by Justice White and joined by Chief Justice Rehnquist and Justices Scalia and Kennedy. Justice $O^{\prime}$ Connor filed a separate concurring opinion. Id. at 452. Justice Brennan wrote a dissenting opinion in which Justices Marshall and Stevens joimed. Id. at 456. Justice Blackmun filed a separate dissent. Id. at 467.

261. Id. at 450 .

262. Id. The Court observed that in 1980 there were 1500 helicopters in use by police in every state in the nation. More than 10,000 private and public helicopters were registered. Id. n.2. 
mum legal altitude estabhished by the Federal Aviation Administration for conventional aircraft, it was lawful for a helicopter to lover at that height. The sheriff therefore had a legal right to be where he was, and he could make whatever plain view observations lie wished. ${ }^{263}$

Certain assumptions about the pervasiveness and notoriety of ordinary aircraft overfliglits im this country underhe the Court's logic im Ciraolo, Dow, and Riley. The Justices have stressed that the overhead vantage point is now a familiar one, and that law enforcement officials im these cases saw no more than anyone else could have seen. According to the Court, no one could reasonably claim ignorance about the possibility of being observed from above, and no one could rationally suppose that protections against ground-level scrutiny sufficc to foreclose all other moritoring attempts.

In fact, in the United States today, overhead surveillancc has become quite common. A wide range of civilian activities such as traffic momitoring, weather prediction, land-use planning, agricultural surveys, and natural resource identification ${ }^{264}$ (not to mention industrial espionage ${ }^{265}$ ), regularly employ aerial photography and other forns of

263. Id. at 451-52. The majority opinion concluded by noting that in this case, "no intimate details connected with the use of the hoine or curtilage were observed, and there was no undue noise, and no wind, dust, or threat of injury." Id. at 452. The first factor-the precision of observation capability -is similar to the critical passage in Dow, quoted at supra note 252, but the latter issuesthe lack of damage or danger to the observed party-are new to fourth amendment jurisprudence. Riley, 488 U.S. at $461-62$ (Brennan, J., dissenting).

Justice O'Connor concurred in the judgment of the Court, agreeing that Riley's expectation of privacy was unreasonable, but declining to base her assessinent so heavily upon the fact that the sheriff's helicopter was operating within legal altitude limitations established by the FAA. Justice O'Connor instead argued that regardless of the FAA provisions, the frequency of overflights at the altitude in question was so great that landowners could not reasonably expect privacy. Her opinion was thus based on the pattern of usage of the airways and not on the FAA regulation. Id. at 452-55 (O'Connor, J., concurring).

The Brennan dissent, recalling Dow and Ciraolo, argued that the defeudant had done everything feasible to protect his privacy, and that even society's toleration of comnercial overflights did not completely erode the expectation that law enforceinent officials would not oversee a backyard. Id. at 456-67 (Brennan, J., dissenting).

264. See De Santis, supra note 80, at 188 (Landsat satelite reconnaissance imagery could help "discover new mineral resources, determine crop yields, facilitate search-and-rescue operations and identify areas of drug production"); White, The Camera Keeps Watch on the World, N.Y. Times, Apr. 3, 1966, Magazine, at 27, 58, 60, 63-64 (use of aerial photography for such purposes as street surveys, industrial estimates, and community planning); Zimmerman, Photos From Space, supra note 80 , at 47-48, 50-53 (many countries now employ satellite reconnaissance capabilities for diverse military and scientific purposes, and private industry is developing similar equipment for journalistic use).

265. Dow Cheimical was not alone in thinking that overhead reconnaissance could coinpromise valuable unpatented trade secrets revealed in the physical layout of a production facility. See E.I. duPont deNemours \& Co. v. Christopher, 431 F.2d 1012 (5th Cir. 1970) (aerial overflight that observed and photographed the construction process of a new inethanol production plant could compromise trade secrets and could constitute improper industrial espionage), cert. denied, 400 U.S. 1024 (1971). 
reconnaissance. The Supreme Court has thrown open the door to gov ernment overflights and monitoring, at least when inspectors use sensors that are relatively ordinary in their sensitivity and relatively unintrusive in their operations.

Nevertheless, these cases also illustrate an intellectual poverty and uncertainty typical of the inost recent Katz progeny that an Open Skies regime will have to confront. Regarding the first prong of the Katz test, for example, it is not at all clear how the imspecting party can know whether a particular person has a subjective expectation of privacy. A mere "hope" that one will not be observed is insufficient, of course, even if buttressed by a significant investment in devices and procedures ainied at frustratimg most observation attenipts. But it reniains unclear how much more a person must do to withdraw legitimately from public scrutiny, especially from high-technology observation that might not yet have attained a substantial degree of public familiarity. ${ }^{266}$

Similarly, the Court seenis bhithely to liave assumed that low-altitude overflights, by both airplanes and helicopters, are coninionplace everywhere; at the least, it lias shifted to the defendant the burden of proving that such overflights are rare in a particular locality. ${ }^{267}$ The Court has also ruled on the question of the public's "expectations" about aerial observations, without offering any real enipirical surveys to determine what the populace really understands about overflights, what it thinks is the probability of privacy im a backyard, or what it knows about

266. See Amsterdam, supra note 216, at 402. Discussing "the question of how tightly the fourth amendment permits people to be driven back into the recesses of their lives by the risk of surveillance," he observes that

so far as I am presently advised of the state of the mechanical arts . . . anyone can protect himself against surveillance by retiring to the cellar, cloaking all the windows with thick caulking, turning off the lights and remaining absolutely quiet. This much withdrawal is not required in order to claim the benefit of the amendment because, if it were, the amendment's benefit would be too stingy to preserve the kind of open society to which we are committed ....

Id.

In United States v. Broadhurst, 805 F.2d 849 (9th Cir. 1986), the prosecutor had argued that the defendants' substantial investment in security apparatus and procedures (designed to protect a greenhouse used to grow marijuana) actually demonstrated that they had expected to be observed by the public and the police, rather than that they had, by dint of their labors, expected privacy. The Ninth Circuit, however, dismissed this argument as an attempt to turn Katz on its head. Id. at 854 n.5.

267. In Riley, the Court twice noted that nothing in the record indicated that helicopter flights at 400 -foot altitudes were uncommon in the locality. $488 \mathrm{U} . S$. at 450,451 . However, the Court did not state the converse: that there was anything in the record to establish that such overflight activity was so frequent and well-known as to destroy any expectation of privacy. Justice O'Connor's concurrence explicitly assigued to the accused the burden of proving that this type of overflight was so rare as to violate an expectation of privacy. Id. at 455 . Dissenting opinions by Justices Brennan, id. at 465-66, and Blackmun, id. at 468, would have the government bear the burden of providing information about customary local flight patterns. See also United States v. Allen, 675 F.2d 1373, 1381 (9th Cir. 1980) (noting frequency of helicopter overflight by Coast Guard in area near U.S. ' coastal border), cert. denied, 454 U.S. 833 (1981). 
the powers of modern reconnaissance. Nor has the Court itself surveyed the frequency of overflights, or of other forms of "aerial" observation such as the patterns of deployment of double-decker buses capable of overlooking tall fences, or the frequency of power outages that legitimately send utility crews scrambling up telephone poles, affording them a special perspective on a neighborhood. ${ }^{268}$ Instead, the Court has rehed upon its members' own common sense and experience, hardly a clear guide for future Open Skies inspectors. ${ }^{269}$

Regarding the second prong of the Katz test, the Court's imquiry into what expectations society deems reasonable has become largely an exercise in question-begging. The Court itself determines what is reasonable, based upon its own instinctive and entirely unpredictable sense of what seems overly imtrusive. ${ }^{270}$ The traditional law of trespass no longer guides this judgment about reasonableness, ${ }^{271}$ because some nontrespassory investigations are nonetheless deemed invasions of protected interests, ${ }^{272}$ while some trespassory incursions onto private property are nonetheless considered to have obtained only information exposed to plain view. ${ }^{273}$ Similarly, the law of unfair trade practices does not govern

268. In United States v. Cuevas-Sanchez, 821 F.2d 248 (5th Cir. 1987), police had installed a videotape camera on top of a utility pole where it could overlook activities conducted behind a tenfoot-high fence surrounding the defendant's backyard. The police there had obtained a judicial warrant before installing the camera, and the appeals court snstained the practice but sharply differentiated the case from Ciraolo. The court noted that unlike one-time overflights, this type of activity intrudes so closely into the private sphere that it could not be justified without a warrant. Cuevas-Sanchez, 821 F.2d at 251.

269. See The Supreme Court, 1985 Term-Leading Cases, 100 HARv. L. REv. 100, 135-43 (1986) (criticizing the Ciraolo and Dow decisions for concluding that if there is a chance that a private person might observe an activity from an airplane, then there can be no lingering expectation that police officials will not do so); Joyce, The EPA's Use of Aerial Photography Violates the Fourth Amendment: Dow Cheımical Co. v. United States, 15 CoNN. L. REv. 327, 329 (1983) (supporting the district court's decision in Dow as inore consistent with fourth amendinent jurisprudence).

The existing case law is also not illuminating on the issue of satellite monitoring. Satellites are so expensive and so heavily regulated that ordinary private citizens could not launch or operate them, whereas the government does so with great frequency. What set of "expectations" about the likelihood of being observed would develop under these circumstances?

270. See U1rited States v. White, 401 U.S. 745, 786 (1971) (Harlan, J., dissenting) ("We should not, as judges, merely recite the expectations and risks without examining the desirability of saddling them upon society.").

271. See Oliver v. United States, 466 U.S. 170, 183-84 (1984) (police trespass was a violation of local law but did not violate the fourth amendinent); Hester v. United States, 265 U.S. 57, 58-59 (1924) (trespass in open fields does not violate fourth amendment). See generally Comment, Dow Chemical and Ciraolo: For Government Investigators, the Sky's No Limit, 36 CATH. U.L. REV. 667 (1987) (tracing the erosion of the linkage between trespass laws and fourth amendment protections).

272. See, e.g., Katz v. United States, 389 U.S. 347 (1967) (even where police did not physically invade the telephone booth, the act of wiretapping infringed defendant's expectation of privacy).

273. See, e.g., Oliver, 466 U.S. at 182-83 (police trespass upon fenced and posted private lands, even if in violation of local criminal law, was not a search under the fourth amendment where there was no breach of a legitinate expectation of privacy); Hester, 265 U.S. at 58-59 (trespass in open fields does not violate fourth amendinent). 
the jurisprudence of the fourth amendment; while an industrial rival is not permitted to steal secrets by overflying a facility under construction, those state laws do not define the parameters of constitutional protection. ${ }^{274}$ The Court, however, has not indicated what other sources of law are more rehable or appropriate in this context.

In essence, the Court has rehied upon introspection to determine whether a particular investigatory technique exceeds tolerable levels. While there are some advantages to admitting that "I can't define a reasonable expectation of privacy, but I know it when I see it," 275 there are social costs in this indeterminacy: Open Skies inspectors and planners will have a hard time divining the limits of their legitimate inspection powers. ${ }^{276}$

\section{$\mathrm{V}$ \\ Is OpEn SKIES A "SEARCh"?: Principles}

Agamst this background, the evaluation of Open Skies and the consideration of any possible constitutional limitations on its implementation will rest upon an assessinent of five factors. Treaty negotiators should address these factors in advance, attempting to build into the treaty legal and institutional arrangeinents that could satisfy the concerns of the Umited States judiciary.

\section{A. The Power of the Collection Methodology}

The Dow dicta about high-technology investigatory techniques ${ }^{277}$ are of great importance to Open Skies. Accordingly, the first inquiry should focus on the strength of the surveillance system. Negotiators

274. See Dow Chem. Co. v. United States, 476 U.S. 227, 232, 239 n.6 (1986) (state tort law governing unfair competition does not define the limits of the fourth amendment); E.I. duPont deNemours \& Co. v. Christopher, 431 F.2d 1012 (5th Cir. 1970) (tort of unfair competition in Texas mcludes obtaining information via nontrespassory aerial overflight, but tort might not apply to objects in "plain view"), cert. denied, 400 U.S. 1024 (1971). But see Dow, 476 U.S. at 248-49 (Powell, J., concurring in part and dissentimg in part) (state tort law reflects the legitimacy of Dow's privacy interest, showing that Dow had a "reasonable expectation of privacy" under the fourth amendment).

275. Cf. Jacobellis v. Ohio, 378 U.S. 184, 197 (1964) (Stewart, J., concurring) ("I shall not today attempt further to define the kinds of material I understand to be embraced within that shorthand description [of hard-core pornography]; and perhaps I could never succeed in intelligibly doing so. But I know it when I sec it, and the motion picture involved in this case is not that.").

276. See National Treasury Einployees Union v. Von Raab, 489 U.S. 656, 672, $677-78$ (1989) (Court upholds inandatory drug testing of Customs Service agents who carry flearms, because they have a diminished expectation of privacy, but asserts inability to assess the corresponding rights of other categories of customs officials); see also Oliver, 466 U.S. at 182-83 (test of legitimacy of the expectation of privacy is whether the government's action intrudes unacceptably upon values protected by Constitution); Note, From Private Places to Personal Privacy: A Post-Katz Study of Fourth Amendment Protection, 43 N.Y.U. L. REv. 968, 983 (1968) (expectation of privacy must be both reasonable and justifiable).

277. See supra text accompanying note 253 . 
must examine three different aspects of the momitoring procedure: (a) the familiarity and prominence of the "collection platform"; (b) the types of sensors used; and (c) the power of individual sensors.

First, how familiar and apparent is the collection platform, the vehicle upon which the Open Skies sensors might be carried? ${ }^{278}$ Katz and its progeny direct attention to the state of public awareness about governinent information-gathering activities, and ask to what extent reasonable people are "on notice" tliat particular searclı capabilities exist. Where a person conducts activities in apparent disregard for known opportunities for oversight by government inspectors, that activity is less likely to be judicially protected than if the presence or potential presence of the inspectors was a carefully guarded secret.

For Open Skies, this calculation probably means that ordinary airplanes are superior platforms: they are so familiar and nonthreatening that no one could be ignorant of the possibility of being overflown by thein. ${ }^{279}$ Hehcopters, by contrast, fly less frequently in many parts of the country. As a result, it may be less reasonable to expect that the public at large should be responsible for protecting against helicopters' special capabilities for hovering and low-altitude flight. ${ }^{280}$ Moreover, unmanned, reinotely piloted drones and reconnaissance satellites are even less familiar to the public. Therefore, failing to guard against those types of observation platforms should not be considered a de facto decision to expose oneself to their plain view. ${ }^{281}$

Second, courts will explore tlie types of sensors used by Open Skies investigators. Again, the more familiar the device and the more pedestrian the types of data it collects, the easier will it be to conclude that failure to protect oneself is effectively consenting to a "plain view"

278. The Ciraolo and Dow courts required the defendant to protect his or her privacy against the particular mode of observation the government might employ. In those cases, guarding against ground-based observation was held insufficient to estabhish a reasonable expectation of privacy from airborne sensors. Comment, supra note 271, at 687-88. This logic suggests that future courts considering an Open Skies agreement might differentiate between several types of aircraft (or spacecraft) that government inspectors might operate.

279. In a similar vein, no one could plausibly claim coustitutional surprise if police observed his or her activities by taking advantage of natural vantage points accorded by a nearby hillside or a neighboring building. Even Dow Chemical conceded that warrantless oversight from natural terrain would be unobjectionable. Dow Chem. Co. v. Umited States, 476 U.S. 227, 234 (1986).

280. See National Org. for Reform of Marijuana Laws v. Mullen, 608 F. Supp. 945, 957-59 (N.D. Cal. 1985) (differentiating helicopters from ordinary aircraft based upon capacity for lowaltitude flight and for hovering); People v. Sabo, 185 Cal. App. 3d 845, 852-53, 230 Cal. Rptr. 170, 17475 (1986) (helicopter hovering at low altitudes in non-navigable air space should be treated differently under the fourth anendment from fixed-wing aircraft and from helicopters in navigable air space), cert. denied, 481 U.S. 1058 (1987). But see Florida v. Riley, 488 U.S. 445 (1989) (treating helicopter identically with ordinary airplane).

281. The Dow dissenters disputed the majority's contrasting satellite surveillance and aerial surveillance, stating that "[t]his type of distinction is heretofore unknown in Fourth Amendment jurisprudence." Dow, 476 U.S. at 250 n.12 (Powell, J., concurring in part and dissenting in part). 
observation. $^{282}$ As discussed above, a wide range of technologies exists. $^{283}$

At one end of the spectrum for Open Skies would be ordinary visible-light photograpliy, which is probably so routine that its use could not easily be cliaracterized as a "search." At the other extreme would be electromic eavesdropping and interceptions, the so-called "signals intelligence" that enables the national security community to capture telephone transmissions, to "bug" a room reinotely, to unscramble electromic emanations, and generally to imspect targeted individuals in a stunning, high-technology manner. Certainly, the American public would not have sufficient awareness of these extraordinary powers to be held legally responsible for evading them in order to preserve privacy. ${ }^{284}$

Between these extreines lies an intriguing range of sensors that future Open Skies crews miglit wish to employ, and that raise serious questions about the degree of public awareness or expectation. Infrared photography, for example, lias become more familiar, but is the public at large so accustomed to the "false color" imagery that passivity counts as consent? What about thermal infrared sensors, which reveal heat gradients? The public probably knows that such tools exist, but assuredly they do not know the true capabilities that could be apphicable to Open Skies. Similarly, everyone has heard of "radar," but the modern synthetic aperture radar mecliamisins are so sophisticated that there is serious doubt that everything they sense could be considered witlin "plain view." Particulate samplers or "sniffers" that can identify invisible radioactive particles spewed from a nuclear test, or that could detect minute quantities of substances evidencing a clremical or biological weapon, are well beyond the public ken. ${ }^{285}$ Even more sophisticated future airborne sensors, such as those which measure disruptions in tle local magnetic

282. For soine Open Skies purposes, ordinary photography will suffice and the inspectors will not seek to einploy inore exotic sensors on their overflights. For other purposes, however, the inspecting state will want to use non-optical sensors, particulate samplers, and devices capable of reading identification "tags" affixed to controlled weaponry. See sources cited supra note 71.

283. See supra text accoinpanying notes 63-74.

284. The existing Open Skies negotiations do not include an authorization for the use of SIGINT, but soine have proposed expanding the program in that way. L. DUNN \& B. HENRY, supra note 37 , at 25 . Courts have traditionally been more suspicious of electronic eavesdropping than of other forms of surveillance. See United States v. Giordano, 416 U.S. 505, 516 (1974) (narrow interpretation of title III of Omnibus Crime Control and Safe Streets Act of 1968 so as to limit the use of intercept procedures); United States v. Kahn, 415 U.S. 143, 153 n.12 (1974) (wiretapping should be only a last resort); United States v. White, 401 U.S. 745, 756-68 (1971) (Douglas, J., dissenting) (electronic eavesdropping poses special type of threat to freedoin); Berger $v$. New York, 388 U.S. 41, 63 (1967) ("Few threats to liberty exist which are greater than that posed by the use of eavesdropping devices.").

285. Recent cases have establislied that there is no reasonable expectation of privacy in garbage that has been positioned for trash collectors, Califormia v. Greenwood, 486 U.S. 35 (1988), or in smoke that has been released into the atmosphere, Air Pollution Variance Bd. v. Western Alfalfa Corp., 416 U.S. 861 (1974). Therefore, Open Skies collection of chennical or radioactive debris 
fields, might be adapted for a future Open Skies agreement. Courts will be called upon to determine whether the use of these unprecedented devices amounts to a "search" under the fourth amendment, or merely provides access to information capriciously exposed to the public. ${ }^{286}$

Third, the courts will look closely at the power of the individual sensors used by Open Skies inspectors. ${ }^{287}$ How great is the resolution obtained by the aerial photography? How revealing is the infrared imagery? How much information does the sniffer actually pick up? The Dow Court, for example, stressed that the EPA photography at issue was imsufficient to read documents or to identify individual people, ${ }^{288}$ suggesting that higher levels of resolution might have occasioned a more exacting analysis.

When considering the power of individual sensors, courts ought to parse two different dimensions of "mtrusiveness" to assess the acceptability of the procedure. ${ }^{289}$ The first is "sensitivity," that is, how great is the sensor's ability to detect small stimuli? The second is "selectivity," that is, how well does the sensor focus on only particular types of information, disregarding other data as irrelevant? In principle, the Constitution would favor devices that were less sensitive and more selective, thereby minimizing the imtrusiveness of the surveillance, but there may be some tradeoffs. For example, a highly sensitive but also highly selective sensor, such as a hypothetical device automatically capable of excluding infornation not germane to military matters, would in primciple be more tolerable than a tool that was both less sensitive and less selective. ${ }^{290}$

ejected into the public airways would probably not be considered a search under the fourth amendment.

286. One intriguing possibility would be to differentiate "active" sensors from those einploying more "passive" ineans. Sensors such as visible light cameras, infrared cameras, and sniffers that merely detect particles or energy emitted by, or naturally reflected from, a target would be in the more acceptable "passive" category. See Corngold v. United States, 367 F.2d 1, 3 (9th Cir. 1966) (not a search for police to use scintillation detector to note radiation sent from defendant's apartment into a public hallway froin contraband wristwatches with radium-treated dials). Sensors such as radars or cameras using artificial illumination, which actively "interrogate" a target, would be considered inore intrusive. But cf. State v. Curtin, 332 S.E.2d 619, 624 (W. Va. 1985) ("A fiashlight merely provides at night what the sun provides during the day.").

287. The dissenters in Dow argued that the majority's focus on the power of the inspection methodology was misplaced, and disapproved of the Court's distinction between satellite and aerial reconnaissance. See supra note 281 .

288. Dow, 476 U.S. at 238 n.5 (Powell, J., concurring in part and dissenting in part).

289. Tanzman, supra note 138 , at 57 .

290. Courts have determined that the use of trained dogs to detect the presence of illegal drugs by scent and to alert human inspectors is not a search under the fourth amendment. United States v. Place, 462 U.S. 696, 707 (1983); United States v. Beale, 736 F.2d 1289, 1292 (9tl Cir.) (en banc), cert. denied, 469 U.S. 1072 (1984). This type of investigation is much more "sensitive" than the use of human senses but is tolerable because it is also much more "selective," detecting ouly the specific aromas the dog has been trained to notice and ignoring all non-contraband. See also $1 \mathrm{~W}$. LAFAVE, supra note $169, \S 2.2$ (d), at $347-55$ (devices such as airport inagnetometer or anti-shoplifting 
The challenge for arms control negotiators, and for the public officials charged with the responsibility for impleinenting an Open Skies agreeinent, will be to inake soine educated guesses about the conclusions that future courts might reach in all three of these uncharted areas. There is, unfortunately, too little precedent to predict confidently how courts will balance the incommensurable factors in any of thein.

Worse yet, the apphication of constitutional principles to Open Skies will reveal some of the illogic and some of the gaps in existing jurisprudence in the core areas of the fourth amendment. Why, for exainple, should public expectations matter so inucli? The text of the fourth amendment certainly does not contain language directing attention to that variable. ${ }^{291}$ Similarly, how should the law treat those public expectations that are irrational or otherwise not grounded in fact? It is far from apparent, for example, why the visible portion of the electromagnetic spectrum should be deeined more accessible than others. Why is the detection and interpretation of sound waves more suspicious than the acquisition of photographs? Why are satellites and helicopters more sinister than airplanes? Why should there be a distinction of constitutional proportions between SIGINT and other technical means of data collection? ${ }^{292}$

In soine instances, moreover, the court itself is flatly wrong about its imphicit expectations. For example, the key passage in Dow in which the Supreme Court atteinpts to differentiate the tolerable degree of aerial photography from the presuinptively more mvasive technology of satelhite reconnaissance ${ }^{293}$ is rooted in misconception. Satellites are not markedly superior for this type of photography, and a resolution of one-lialf

sensormatic detection systems, which react only to certain specified items, may be relatively tolerable).

291. The point asserted by the prosecution in United States v. Broadhurst, 805 F.2d 849 (9th Cir. 1986) (discussed at supra note 266), deserves more serious attention in this context. Some people (such as spies, organized crime bosses, and marijuana growers) often have reason to expect that the government will try to detect their aetivities. That fear is one of the key reasons for the great precautions they take-precautions that show not that they subjectively expect privacy, but that they are well aware of the threat that the government will attempt to discover their activities. They certainly hope they will escape notice, and each one of thein probably thinks that he or she has managed to avoid detection-otherwise, they would not conduct the particular conversation, sale, or other transaction while they are under surveillance. See United States v. White, 401 U.S. 745, 751 (1971).

But this concept of "expectations" has a different meaning from its usual application to people who have no special cause to suppose that they might come under government surveillance, and the concept is attenuated in the nationwide context of Open Skies. See Amsterdam, supra note 216, at 384-85 (courts' concern with expectations should not focus on a prediction about the actual degree of privacy expected, but on justified reliance on society's rejection of this type of warrantless surveillance).

292. See 1 W. LAFAVE, supra note $169, \S 2.2(\mathrm{e})$, at 359-60 (discussing differences between police observation via visual and audio surveillance).

293. Dow Chem. Co. v. United States, 476 U.S. 227, 238-39 (1986). 
inch (as obtained by the EPA airplane) is extremely good under any circumstances. Indeed, one of the primary justifications for Open Skies is the prospect that close-flying aircraft could provide even better imagery and data collection than orbiting satellites. ${ }^{294}$

Similarly, the judicial fealty to public expectations, coupled with the fact that public knowledge and opinions can change over tinie, raises the specter that the government might someday deliberately attempt to alter public expectations. Could federal or local authorities legitimately expand the scope of Open Skies nonsearch investigations by persuasively advertising the true power of their satellite and aerial reconnaissance? If the government, instead of keeping its intelligence-gathering capabilities a secret, aggressively displayed them, highlighting the nature and power of modern oversight strengths, public expectations would surely change. Under current jurisprudence, such a change in public expectations could restrict the coverage of the fourth amendment precisely when its protections were most needed. ${ }^{295}$

The special role of the United States government in the Open Skies surveillance program also raises other problems. In Ciraolo and Riley, the Supreme Court stressed that any other nembers of the public could lawfully position themselves where the pohice had been and could therefore niake and record the same observations. ${ }^{296}$ In Dow, this argument was presented as a major factor supporting the legality of the governnient's activities. ${ }^{297}$ Every parent, however, has learned the necessity for forinulating a better response than the Court's to the argument that "all the other kids can do it, so why can't I?" Some things are tolerable when done by private persons, but should be prohibited when done by the government; the aerial reconnaissance cases have glossed over that distinction too quickly. ${ }^{298}$ Perhaps future Open Skies litigation will require us to revisit that troublesome issue more carefully.

294. See supra text accompanying notes 63-74 and 79-91.

295. But see Amsterdam, supra note 216, at 384 (government announcements about new surveillance practices could not suffice to nndercut the coverage of fourth amendment).

296. Florida v. Riley, 488 U.S. 445, 450-52 (1989); Dow, 476 U.S. at 231.

297. The dissenting opmion, however, noted that in view of the prohibitive cost of the camera used by EPA, members of the pnblic would be unlikely to replicate the reconnaissance. Dow, 476 U.S. at 251 n.13 (Powell, J., concurring in part and dissenting in part).

298. See California v. Greenwood, 486 U.S. 35, 54 (1988) (Brennan, J., dissenting) ("The mere possibility that unwelcome [nongovernmental] meddlers might open and rummage through the [trash] containers does not negate the expectation of privacy in their contents any more than the possibility of a burglary negates an expectation of privacy in the home ...." (emphasis in original)); Bivens v. Six Unknown Named Agents, 403 U.S. 388, 392 (1971) ("Our cases have long since rejected the notion that the Fourth Amendment proscribes ouly such conduct as would, if engaged in by private persons, be condemned by state law."); The Supreme Court, 1985 Term-Leading Cases, supra note 269, at 141 (the Court in Dow proceeds on the "dubious assumption" that a person's willingness to accept exposure to casual overflight by high altitnde commercial airliners is automatically also a willingness to accept inspection at close range by police). 


\section{B. The Purpose of the Search}

When a court in a fourth amendinent case gets to the hard work of balancing the government's interest in conducting the search against the target's interest in retaining privacy, ${ }^{299}$ part of the calculation requires a fine analysis of the government's motivation for the investigation and the importance of the inquiry.

In the typical fourth amendment case, the government's purpose is quite straightforward: to accumulate evidence of a crime and prove a link between a particular defendant and the crime's commission. The individual's stake is equally obvious: to preserve his or her liberty by suppressing illegally obtained evidence.

An Open Skies regime, however, serves a different set of purposes and a different constellation of interests. The purpose of the search is to demonstrate American coinphance with the terms of international agreements and otherwise to establish the absence of threatening inilitary activities. The United States government will approach the investigations with an interest in presenting the evidence to the Soviet Union or to other states in the court of world opimion, and not with an interest in a domestic criminal prosecution of any individual citizen. ${ }^{300}$ The goal is not to threaten an individual's hiberty, but to demonstrate American bona fides to the satisfaction of other states. ${ }^{301}$

The constitutional balancing will therefore focus on the importance of Open Skies to a regime of international arms control. As noted above, ${ }^{302}$ we can expect American courts to defer in large measure to the government where search activities imphicate foreign affairs and national security concerns. But the judicial inquiry is nevertheless likely to be

299. See United States v. Place, 462 U.S. 696, 703 (1983) (identifying interests to be balanced in fourth amendment criminal cases). Some authorities consider that this type of balancing is inherent in fourth amendment litigation, and that despite the seemingly stark prohibitive language of the Bill of Rights, courts will always trade off the social values and try to develop an outcome that is reasonable under the circumstances. See Amsterdam, supra note 216, at 354, 403 (court must make value judgments that accommodate the conflicting interests of law enforcement and civil liberties); Wasserstrom, supra note 187, at 129 (court has adopted a balancing test of general reasonableness).

300. The United States Government will, of course, have a continuing interest in the suppression of crime, and the other parties to an Open Skies agreement may also have a stake in a criminal ease where an individual American is charged with violation of a law relevant to the himitations of an arms control agreement. But the overriding purpose of the agreement will concern the exchange of military data, and derivative applications for criminal prosecution will be of secondary importance.

301. Cf. National Treasury Employees' Union v. Von Raab, 489 U.S. 656, 665 (1989) (where the purpose of employee testing for drug or alcohol consumption is public safety rather than criminal prosecution, the "intrusion serves special governmental needs, beyond the normal need for law enforcement" and a special balancing test is required to weigh the government's interest against the individual's privacy interest); Skinner v. Railway Labor Executives' Ass'n, 489 U.S. 602,619 (1989) (same).

302. See supra notes $182-84$ and accompanying text. 
vigorous, and arms control negotiators and implementors cannot prudently count on the courts to accept reflexively the assertions of the executive branch. Instead, courts will look carefully at the facts: how much does the Open Skies treaty actually promote national security? What is its inarginal contribution to the safety of the Umited States, in an era when all inanner of other international accords are being fashioned? ${ }^{303}$ How important is it that the overflights occur, and that they occur on short notice and without any opportumity for judicial intervention? ${ }^{304}$ Even with a completely uninhibited regime of Open Skies, the Umited States would not enjoy perfect security, and even without it, the country would not be plunged into open hostilities. It will therefore certainly not be sufficient to invoke a national security talisinan; the courts will have to be satisfied that this set of measures, with warrantless investigations occurring on a vast scale, inakes an important contribution to the overarching governmental goal.

The government can readily adapt information acquired by the Open Skies overflights for inultiple purposes in the Uinited States and elsewhere, ${ }^{305}$ coinphicating the analysis of the government's purpose. Synergistic use of the accumulated data nnight becoine important in a future Open Skies regime. Already, analysts have suggested that Open Skies imagery and other data can profitably assist econonnic analysis (by estnnating factory production, agricultural status, etc.), environmental assessment (by measuring pollution levels, deforestation, erosion, etc.) and inapping. ${ }^{306}$ It does not strain the innagination, therefore, to foresee that law enforceinent might also becoine a routine beneficiary. ${ }^{307}$

In this context, Open Skies will collide with yet another area of

303. See Halkin v. Helms, 598 F.2d 1, 8-9 (D.C. Cir. 1978) (in law enforcement or intelligence gathering, the significance of any one piece of information often depends upon its relationship to an overall pattern of knowledge; data that seem trivial may become crucial when combined witl other sources).

304. The district court in Dow did uot decide that the inspections and overflights could uot occur, only that they could not occur without a prior warrant, because the admittedly valid purpose behind the government's imquiry would not be unduly frustrated by the interposition of a pre-search judicial review. Dow Chem. Co. v. Uuited States, 536 F. Supp. 1355, 1369-70 (E.D. Mich. 1982), rev'd, 749 F.2d 307 (6th Cir. 1984), aff'd, 476 U.S. 227 (1986).

305. The current NATO proposal calls for sharing the Open Skies data within military blocs, NATO Press Service, supra note 39 at 4-5; the Soviet Union has called for even wider dissemination, USSR Foreign Ministry Press Center, supra note 112, at 80; Warsaw Treaty Organization, supra note 112 , at 1 .

306. OPEN SKIES AIRCRAFT, supra note 65, at 5.

307. Courts have frequently inquired into the government's exact purposes in conductiug warrantless investigations, and lave afforded greater leeway to uational security cases with a "strategic intelligence" objective (for example, gathering information about the activities of a spy, the operation of an espionage ring, and the meehanisms for collecting and forwarding stolen secret papers). Where the government's purpose is not to collect strategic information but to accumulate evidence for criminal prosecution, courts have required a warrant. See, e.g., Zweibon v. Mitchell, 606 F.2d 1172 (D.C. Cir. 1979), cert. denied, 453 U.S. 912 (1981). 
uncertainty im fourth amendment law, the requirement of probable cause. Open Skies will present a unique problem here because foreign crews will determine where and when to fly over the United States, what sorts of sensors to use, and where to aim them. The foreign crews will have the power to make these decisions entirely on their own, for any reason or for no reason at all. They can proceed on the basis of clues provided by other intelligence sources such as NTM, anonymous "tips," or random chance.

The fourth amendment, however, was designed to preclude precisely this type of governmental caprice. Accordingly, the drafters required the government to accumulate a certain quantum of imformation imdependently before it could mvade the citizen's privacy. ${ }^{308}$ Police may not conduct searches randomly or based on unsupported hunches, but must do their homework in other ways before applying for a warrant.

In Ciraolo, the trial court noted that the Santa Clara police had singled out the defendant's home for overflight and photography on the basis of evidence that would not amount to probable cause for the issuance of a warrant. The court differentiated between this circumstance and unfocused, routime patrols that might happen to overfly Ciraolo's home and chance to look down. ${ }^{309}$ The Supreme Court, however, questioned whether this was a rational distinction and had "difficulty understanding exactly how respondent's expectations of privacy from aerial observation might differ when two airplanes pass overhead at identical altitudes, simply for different purposes."310 Open Skies would add another category of overflights, with aircraft operating for other purposes, unconnected to either pohice "routine patrols" or "focused suspicion." Therefore, Open Skies nnight force the Supreme Court to address the issue more directly.

Open Skies might also require the Suprente Court to resolve another aspect of the lingering ambignity about the purposes of a search: whether the restrictions on the government differ where no liberty interests-the core of what the fourth amendment protects-are implicated. Specifically, in a case such as Open Skies treaty implementation (which does not imvolve criminal prosecution), does the fourth amendment permit the government to exercise greater power than usual, because there is

308. But see National Treasury Employees' Union v. Von Raab, 489 U.S. 656, 668 (1989) (authorizing warrantless drug testing of general categories of government employees without individualized probable cause, as "suspicionless searches" justified by special governmental needs); Skinner v. Railway Labor Executives' Ass'n, 489 U.S. 602, 624 (1989) (finding that drug testing of railroad employees without individualized suspicion furthers important government interests and is "reasonable despite the absence of such suspicion").

309. People v. Ciraolo, 161 Cal. App. 3d 1081, 208 Cal. Rptr. 93 (1984), rev'd, 476 U.S. 207 (1986).

310. California v. Ciraolo, 476 U.S. 207, 214 n.2 (1986). 
no reason to be concerned that an individual's personal freedom is at stake? Or does the Constitution in these circumstances provide the law enforcement officials less power than usual, because the government's interest in suppressing a particular activity is ordinarily not as high as in situations that do involve crime? ? $^{311}$

\section{The Character of the Place to Be Searched}

The Supreme Court has long held that "the Fourth Amendinent protects people, not places."312 In other words, the scope of state laws regarding trespass and other property interests does not define the nature of constitutional protections. ${ }^{313}$ Nevertheless, the Court has also acknowledged that the nature of the physical location or the character of the place to be searched strongly affects the degree to which an individual can sustain a reasonable expectation of privacy in a particular activity. $^{314}$

Thus, courts have consistently differentiated commercial properties from domiciles, ${ }^{315}$ and within the domestic area, they have accorded increasing protection to the concentric rings of "open fields,"316 "curtilage," 317 and the home itself. In both Riley and Ciraolo, for example, the marijuana detected by aerial surveillance was within the curtilage, triggering a relatively high standard of scrutiny. ${ }^{318}$ In Dow, even though the

311. See Dow Chem. Co. v. United States, 536 F. Supp. 1355, 1368 (E.D. Mich. 1982) (society is particularly likely to view nitrusive government surveillance as unreasonable when it is applied in a noncriminal context), rev'd, 749 F.2d 307 (6th Cir. 1984), aff'd, 476 U.S. 227 (1986); Camara v. Municipal Court, 387 U.S. 523, 530 (1967) (it is "anomalous to say that the nidividual and his private property are fully protected by the Fourth Amendment only when the individual is suspected of criminal behavior").

312. Katz v. United States, 389 U.S. 347, 351 (1967).

313. See supra notes 271-73 and accompanying text.

314. See Oliver v. United States, 466 U.S. 170, 178, 182-83 (1984); Katz, 389 U.S. at 361 (Harlan, J., concurring).

315. The Court has called protection of the home the basic purpose of the fourth amendment. See United States v. Karo, 468 U.S. 705, 714-15 (1984); Welsh v. Wisconsin, 466 U.S. 740, 749 (1984); Steagald v. United States, 451 U.S. 204, $211-12$ (1981); Silverman v. United States, 365 U.S. 505,511 (1961). Businesses have a reduced expectation of privacy but still enjoy a substantial degrec of fourth amendment protection. See Donovan v. Dewey, 452 U.S. 594, 598-600 (1981) (allowing "greater latitude" to conduct warrantless inspections of commercial property because of lesser expectation of privacy); Marshall v. Barlow's, Inc., 436 U.S. 307, 311-13 (1978) (establishing that fourth amendment prohibition against unreasonable searches apphies to administrative searches of private commercial property); Sec v. City of Seattle, 387 U.S. 541, 545-46 (1967) (concluding that warrant procedure applies to nonconsensual administrative searches on business premises).

316. See, e.g., Oliver v. United States, 466 U.S. 170, 182-83 (1984); Air Pollution Variance Bd. v. Western Alfalfa Corp., 416 U.S. 861, 865 (1974).

317. The curtilage is defiued as the area immediately surrounding the dwelling and closely associated with it, sharing nuany of its uses and deserving similar protections. United States v. Dunn, 480 U.S. 294, 300-01 (1987); Oliver, 466 U.S. at 180.

318. Florida v. Riley, 488 U.S. 445 , 450 (1989); California v. Ciraolo, 476 U.S. 207, 212-14 (1986). 
company attempted to argue that the entire manufacturing facility constituted an "industrial curtilage," the Supreme Court decided that for purposes of aerial inspection, the plant was inore akin to "open fields" and thus deserved much less protection. ${ }^{319}$

Open Skies aircraft, however, would iguore these fine legal distinctions. The arms control inspectors would have authority to overfly the entire country, and would be free to keep their cameras clicking over farms, forests, factories, and lomes. Military structures, of course, would be of the greatest interest, and, on inost occasions, peering into someone's backyard would waste time and film. Nevertlieless, a major purpose of Open Skies flights would be to explore "ambiguous circumstances," and sucli circumstances will undoubtedly present themselves on or near private property. Consequently, there can be no broad exclusions froin the blanket power to overfly and use ligh-powered sensors. The constitutionality of the overflight regime can be no stronger than its weakest legal link, and the entire treaty regime will fall if residential scrutiny is deeined impermissible.

The "cliaracter of the place" analysis inay also imphicate the types of sensors employed on an Open Skies mission. ${ }^{320}$ One "place" ordinarily considered "safe" is indoors; people generally liave a very ligh expectation of privacy regarding activities conducted inside buildings. ${ }^{321}$ Unless a missing roofing panel, ${ }^{322}$ an unclosed door, ${ }^{323}$ or a window witlout curtains ${ }^{324}$ provides an unobstructed view from a public area, courts gen-

319. The concept of an "industrial curtilage" was a novel argument in fourth amendment hitigation. The Court reasoned that Dow's facility "can perhaps be seen as falling somewhere between 'open fields' and curtilage, but lacking some of the critical characteristics of both." Dow Chem. Co. v. United States, 476 U.S. 227, 236 (1986).

320. See supra notes $282: 86$ and accompanying text.

321. In Dow, the district court was careful to explain how the scenes depicted in the EPA photographs more closely approximated "interior" regions of the overall facility, even though only the "exteriors" of individual buildings and pipes were visible. Dow Chem. Co. v. United States, 536 F. Supp. 1355, 1357 \& n.3 (E.D. Mich. 1982), rev'd, 749 F.2d 307 (6th Cir. 1984), aff'd, 476 U.S. 227 (1986); see also Umited States v. Allen, 675 F.2d 1373, 1380 (9th Cir. 1980) (approving the use of various high-technology surveillance devices, but noting that the case did not involve the use of vision-enhancing equipment to peer into the interiors of buildings), cert. denied, 454 U.S. 833 (1981); Uinted States v. Kim, 415 F. Supp. 1252, 1256-58 (D. Haw. 1976) (prohibiting warrantless use of high-powered telescope to see details inside residence). But see United States v. Broadhurst, 805 F.2d 849, 856 (9th Cir. 1986) (translucent walls or roof may reduce expectation of privacy in a building such as a greenhouse).

322. Florida v. Riley, 488 U.S. 445,450 (1989).

323. See, e.g., United States v. Dunn, 480 U.S. 294, 305 (1987) (officers' use of a flashlight beam directed through the essentially open front of defendant's barn did not transform their observations into a search); United States v. Conner, 478 F.2d 1320, 1323 (7th Cir. 1973) (police officers' observation of interior of garage from outside prior to entry did not constitute a search); People $v$. Wheeler, 28 Cal. App. 3d 1065, 1069, 105 Cal. Rptr. 56, 58 (1972) (observation through open garage door lawful regardless of whether the illumination permitting the observation is natural light, artificial hight, or light from a flashlight held by an officer).

324. See, e.g., United States v. Johnson, 561 F.2d 832, 842 (D.C. Cir.) (not unreasonable for 
erally consider the interior of a building to be shielded from public scrutiny. ${ }^{325}$

Soine Open Skies sensors, lowever, may have the capacity to look througli walls and roofs. Advanced radars and infrared cameras can detect evidence of activities or objects that are hidden from ordinary eyesiglit or photograpliy. The potential to peer through opaque structuresthe fear the Dow Court voiced ${ }^{326}$-is not as futuristic as it may seem, and Open Skies negotiators and implementors will lave to deal with it sooner rather than later.

\section{Opportunities for Minimization}

Courts examining an Open Skies regime will no doubt inquire whetlier other procedures or standards could be developed to minimize the intrusions on privacy witlout unduly coinpromising the government investigation. ${ }^{327}$ If less invasive alternatives exist for accomplishing the national security objectives, or if the government could create partial protections to serve both sets of interests adequately, the courts will pursue them. . $^{328}$

One such partial measure could be blanket invocation of an

officer who observed narcotics operation through open window to wait half an hour for reinforcements before entering), cert. denied, 432 U.S. 907 (1977); Lorenzana v. Superior Court, 9 Cal. 3d 626, 638, 511 P.2d 33, 42, 108 Cal. Rptr. 585, 594 (1973) (unreasonable search where eavesdropping officer stood upon private property that exhibited no invitation to public use); State v. Dickerson, 313 N.W.2d 526, 532 (Iowa 1981) (not a search for police to look through window of front door, take photographs of the interior, and enlarge the pictures to reveal more detail); State $v$. Crea, 305 Minn. 342, 346, 233 N.W.2d 736, 740 (1975) (not unreasonable for police without warrant to shine light through baseinent window to view stolen snowmobiles inside).

325. See United States v. Karo, 468 U.S. 705, 718 (1984) (warrantless use of electronic "beeper" to monitor movement of items on public highways is permissible, but using the beeper to reveal the presence of items inside a home requires a warrant); Commonwealth v. Williams, $494 \mathrm{~Pa} .496,500$, 431 A.2d 964, 966 (1981) (extended, continuous observation via binoculars and startron of private activities conducted inside apartment is unreasonable). The area surrounding the hoine also benefits froin special protections. See California v. Ciraolo, 476 U.S. 207, 215 n.3 (1986) (government concedes that "[a]erial observation of the curtilage may become invasive, either due to physical intrusiveness or through modern technology which discloses to the senses those intinate associations, objects or activities otherwise imperceptible to police or fellow citizens").

326. Dow Chein. Co. v. United States, 476 U.S. 227, 239 (1986).

327. In ordinary law enforcement operations, a judicial finding that a "search" has occurred does not necessarily mean that the activity must come to a halt; rather, it simply requires a warrant procedure inserting review by a disinterested judicial figure between the law enforcentent officers and the public. See United States v. White, 401 U.S. 745, 789-90 (1971) (Harlan, J., dissenting); see also Bionic Auto Parts \& Sales v. Fahner, 721 F.2d 1072, 1079 (7th Cir. 1983) (state inust tailor inspection procedures to its proper objectives and must minimize the dangers inherent in the unbridled exercise of administrative discretion). In the context of Open Skies, however, the warrant requirement would be so inconsistent with the structure of the treaty that the two could not coexist.

328. The entire area of "adininistrative searches," for example, was a creation of the Suprenie Court, as it attempted to fashion a modus vivendi between the interests of government inspectors and the concerns of private property owners. See supra note 218 and accompanying text. The Court developed a nodified warrant procedure that permitted the inspections, but still accorded soine 
exclusionary rule, specifying in advance (in the treaty or in domestic impleinenting legislation) that all information produced by or derived from Open Skies operations would be inadmissible in any criminal or other punitive proceeding. This would ease inany apprehensions about undue government searches without jeopardizing the purpose of Open Skies. This strategy, however, would provide ouly a partial solution to the problem, since the purpose of the fourth amendinent is to bar certain unwanted categories of government actions, not simply to deny to prosecutors the fruits of unconstitutional acts. ${ }^{329}$

Negotiators should also address other possible limitations on Open Skies that might prove interesting to courts. For example, the public might benefit from advance notice of the inspectors' intended routes. The government will obviously know the flight plan; perhaps the public should know it as well. While the short time frame of the inspections will impede important military-related concealment, it might enable private citizens who cared to do so to remove themselves from observation. At the very least, the notification process could provide the government another plausible argument to assert in court.

Similarly, Open Skies operators could provide overflown owners or occupants with copies of the photography and other information obtained during recoimaissance. The current NATO proposal for Open Skies does not contemplate this type of sharing of the acquired data, but it might ease the fears of the overflown populace.

It may be, however, that the government should take exactly the opposite approach and place greater restrictions upon the dissemination and use of Open Skies information. The government could perhaps ameliorate some of the privacy concerns raised by Open Skies if it assured citizens that imagery would not be available to the public, leaked to neighbors or competitors, or displayed in an embarrassing or offensive fashion. This strategy could also permit distinctions based on the content of the information: the government could restrict photographs of hoines more than those of uninhabited wilderness; similarly, the government could guard imagery from sensors that could penetrate roofs more tightly than conventional pictures.

protections to the citizenry. See See v. City of Seattle, 387 U.S. 541 (1967); Camara v. Municipal Court, 387 U.S. 523 (1967).

329. In the Dow case, for example, the exclusionary rule was irrelevant as a remedy because the case did not arise as a criminal prosecution; the company initiated the action as an offensive suit, seeking a deelaratory judgment and an injunction. Dow Chem. Co. v. United States, 536 F. Supp. 1355, 1357 (E.D. Mich. 1982), rev'd, 749 F.2d 307 (6th Cir. 1984), aff'd, 476 U.S. 227 (1986); see also Skinner v. Railway Labor Executives' Ass'n, 489 U.S. 602, 622 (1989) (finding that a warrant requirement would contribute little to individuals' protections against improper intrusions under a mandatory drug testing regime with well-known and narrowly defined regulations). Compare the fifth amendment's protection against self-incrimmation, which the government may circumvent by granting immurity from prosecution. Kastigar v. United States, 406 U.S. 441, $460-61$ (1972). 


\section{E. Recourse for Abuse}

A court might also ask what possible recourse the Open Skies program affords to aggrieved individuals attempting to vindicate their asserted rights. Three possibilities emerge: self-help, damages, or injunction.

The first recourse for aggrieved individuals is self-help. As noted above, ${ }^{330}$ the Open Skies agreement would not impose direct responsibilities or compulsions upon the ordinary citizen. The government would not require private persons to change their behaviors, admit foreign inspectors into their homes or busimesses, or refram from concealing or sheltering their private activities. While Open Skies would thus not require a privacy-seeking individual to "retire to the cellar," ple expedient would remain for each individual to withdraw from overhead view anything he or she did not care to permit foreign crews to oversee. Ciraolo, Dow, and Riley already require this degree of self-protection, and Open Skies would add only marginally to people's existing wariness of conducting activities outdoors. ${ }^{332}$

A second recourse would be to sue either the United States Government or the foreign inspectors for damages resulting from losses incurred through the operation of Open Skies. ${ }^{333}$ As noted above, ${ }^{334}$ such a suit would need to allege nivasion of privacy or conversion of trade secrets acquired through overflight, ${ }^{335}$ and would have to surmount substantial

330. Supra notes $159-63$ and accompanying text.

331. Amsterdam, supra note 216, at 402.

332. This type of private self-help would not disrupt the implementation of an Open Skies agreement. Most activities that are large enough to be important to the overflights would be impossible to conceal or to move indoors. Where arms control negotiators do want to deal with sinall, portable items, they will have to draft substantive treaties that include additional verification procedures aimed at those specific problems.

333. See Carlson v. Green, 446 U.S. 14, 20 (1980) (damages action for violation of fourth amendinent proper under either Bivens or the Federal Tort Claims Act, 28 U.S.C. $\$ 2680(\mathrm{~h})(1988)$ ); Bivens v. Six Unknown Named Agents, 403 U.S. 388, 397 (1971) (government agents' violation of fourth amendinent gives rise to private cause of action for damages).

334. See supra notes $151-52$ and accompanying text.

335. A different type of lawsuit could arise if a government contractor-who had a statutory or contractual responsibility for maintaining the confidentiality of official secrets im its possession-was suddenly required to do even more to protect those secrets because of new treaty-required inspections. For exanple, the contractor might have to erect a new dome or roof to cover open areas, bring more activities indoors, or modify the materials used to construct the walls and roofs of its buildings. Many future arms control agrecments may result in this type of lawsuit, and the potential for such a lawsuit has alrcady surfaced in conneetion with the INF Treaty, which includes provisions for a permanent Soviet inspectorate outside the Hercules imissile facility near Magna, Utah. See Morrison, supra note 95, at 2580; Summary and Text of the INF Treaty and Protocols, ARMS CONTROL TODAY, Jan./Feb. 1988, INF Supp. 16. A future chemical weapons agreenent would also likely include inspection provisions that could exacerbate this problem. See Barrett, Verification of a Chemical Weapons Ban: The On-Site Inspection Burden, in ARMS CONTROL Verification \& THE New Role OF ON-STTE INSPECTION 139-58 (L. Dunn ed. 1990); Morrison, supra note 95, at 2581. But Open Skies will not trigger as much new activity in this area, since 
procedural hurdles ${ }^{336}$ such as sovereign or official immunity ${ }^{337}$ and the pohitical question doctrine. ${ }^{338}$ But sone parties might well be able to frame such a suit to allege the type of concrete, individualized hann necessary for standing, ${ }^{339}$ and the treaty itself, or its implementing legislation, could facilitate the process of hearing individuals' conılaints by expressly creating a cause of action. ${ }^{340}$

Protecting trade secrets, in particular, will beconie a major issue in future arms control negotiations, ${ }^{341}$ and the Open Skies agreeinent inay be on the leading edge of this trend. ${ }^{342}$ As the inspection powers involved in verification becone nore invasive and comprehensive, private businesses will worry-with good reason-that valuable trade secrets and production processes will fall into the hands of conipetitors in the inspecting state or elsewhere. ${ }^{343}$ Even if the United States Govern-

routine overflight by Soviet and other reconnaissance satellites has already driven most classified activity indoors.

336. See J. MOORE, F. TIPSON \& R. TURNER, supra note 187, at 1028-29; Rotenberg, Private Remedies for Constitutional Wrongs-A Matter of Perspective, Priority, and Process, 14 HASTiNgs CONST. L.Q., Fall 1986, at 77, 86.

337. See supra note 154 and accompanying text; see also Butz v. Economou, 438 U.S. 478 (1978) (establishing qualified immumity for federal officials from damages suits); Chagnon v. Bel1, 642 F.2d 1248 (D.C. Cir. 1980) (immurnty of Attorney General and those working at his discretion for warrantless wiretapping), cert. denied, 453 U.S. 911 (1981); Halkin v. Helms, 598 F.2d 1 (D.C. Cir. 1978) (denying relief in case alleging illegal wiretapping by various federal agencies).

338. Courts lave shown considerable deference to the executive branch in the conduct of foreign affairs, as they are reluctant to complicate interactions with foreign sovereigns. See supra notes 182-84 and accompanying text. More generally, the political questions doctrine posits the existence of "certain constitutional question which are inherently non-justiciable. These "political question,' it is said, concern matters as to which departments of government other than the courts, or perlaps the electorate as a whole, inust have the final say." L. TRIBE, AMERICAN Constitutional Law § 3-13, at 97 (1988).

339. See Brown v. United States, 411 U.S. 223, 229 (1973) (defendant who had no reasonable expectation of privacy or interest of any kind in the premises searched had no standing to contest admissibility of evidence seized there); United States v. Broadhurst, 805 F.2d 849, 851-52 (9th Cir. 1986) (fourth amendment rights are personal, and only the individual whose privacy interests have been infringed may assert them.)

340. See D. ARONOWITZ, supra note 144, at 151-53 (arins control agreement could provide imternational remedies, create an adjudication tribunal, and mandate the creation of a trust fund to pay compensation for damage done by inspectors).

341. Id. at 150-51 (the umique claracter of injuries to trade secrets warrants special attention, and an arms control regime should establish a suitable program of remedies).

342. The cliemical weapons convention now under negotiation squarely raises the issue of protecting commercial secrets, and the negotiators lave devoted considerable attention and specific provisions of the treaty text to addressing industrial concerns. See 1 THE ChEMICAL INDUSTRY and the Projected Chemical Weapons Convention 30-31 (1986) (Proceedings of a SIPRI/ Pugwash Conference) [hereinafter THE CHEMICAL INDUSTRY]; Carpenter, Government Regulation of Chemical Manufacturing in the USA as a Basis for Surveillance of Compliance With the Projected Chemical Weapons Convention, in 2 THE ChemiCal INDUSTRY, supra, at 11, 22-24; Hoffmann, Some Aspects of Verification From the Viewpoint of the Chemical Industry of the Federal Republic of Germany, in 2 THE CHEMICAL INDUSTRY, supra, at 97-104.

343. Most often, overliead reconnaissance does not revcal any important trade secrets that are not easily obtainable in other ways, but in certain circumstances the layout of a facility, the testing of 
ment does not deliberately misuse the acquired information, it might be liable if the data acquired under its protection leaked to foreign or domestic industrial rivals. ${ }^{344}$ Private corporations will therefore have a significant stake in the miplementation of an Open Skies agreement, and negotiators have already signaled their awareness and understanding of the issue and have accepted responsibility for guarding against the prospect that aerial observation could provide a cover for commercial espionage. $^{345}$

Moreover, it makes sense for public pohicymakers to deal directly and prospectively witl these unfair competition concerns. ${ }^{346}$ Open Skies, after all, is a matter of national strategy, undertaken for the good of the society as a whole, and its costs should appropriately be spread over the entire country rather than falling on those few wlio are affected by the accidents of chance or the choices of foreign governments.

The third possible avenue of recourse against abuse would be to seek an injunction against implementing Open Skies. Such a suit would provide the most direct challenge to the arms control regime, and would be a plausible approach for testing the constitutionality of a government action that inflicts a very small amount of actual damage, but inay do so upon milhions of overflown individuals.

Again, the procedural problems are profound, ${ }^{347}$ but courts have issued injunctions im similar cases. In Marshall v. Barlow's, Inc., ${ }^{348}$ for example, the Supreine Court upheld the grant of an injunction on fourth amendinent grounds, barring the enforceinent of a program of warrantless inspections undertaken by the Occupational Safety and Health

new products, or the patterns of incoming and outgoing traffic might be revealing. In Dow Chemical Co. v. United States, 476 U.S. 227 (1986), and in E.I. duPont deNennours \& Co. v. Christopher, 431 F.2d 1012 (5th Cir. 1970), cert. denied, 400 U.S. 1024 (1971), a corporation felt sufficiently threatened by aerial photography that it sustained protracted hitigation.

344. See Megapulse, Inc. v. Lewis, 672 F.2d 959 (D.C. Cir. 1982) (damages for violation of trade secrets).

345. See Opering Statement by Sergiu Celac, supra note 46 , at 4 ("[P]articipating States should be protected against possible cominercial use, without their consent, of the information and data acquired by the observing state.").

346. In article IX of the PNE Treaty Protocol, the parties specified that proprietary rights in information would be undisturbed by the treaty, that claims about the protection of those rights would not impede impleinentation of the treaty, and that neither party could release information to the public without the consent of the other. PNE Treaty, supra note 78, Protocol, art. IX, S. Exec. Doc. N, 94th Cong., 2d Sess. 5, 22 (1976), 15 I.L.M. 891, 900, reprinted in ACDA TREATY Book, supra note 2, at 194, 209.

347. See City of Los Angeles v. Lyon, 461 U.S. 95, 106 (1983) (injunction deried where there was no proof that plaintiff was likely to be injured again in the future by police behavior); Halkin $v$. Helins, 598 F.2d 1 (D.C. Cir. 1978) (denying rehef in ease alleging illegal wiretapping); J. MOORE, F. TIPSON \& R. TURNER, supra note 187, at 1028-29 (describing reinedies for fourth amendinent violations); Tanzman, supra note 138, at $39 \mathrm{n} .117$ (listing cases in which plaintiffs have sought injunction for fourth amendment violations).

348. 436 U.S. 307 (1978). 
Administration. ${ }^{349}$ The Court did not hesitate to strike down an important series of government investigations where it found that the protections for businesses were inadequate. ${ }^{350}$ While it might be possible for Congress to pass a statute prohibiting injunctions in arms control cases, such an act would be complicated and legally and politically probleinatic. ${ }^{351}$

\section{CONCLUSION}

To a reinarkable degree, the concerns of thirty-five years ago are still the concerns of today. The debates about Open Skies in the 1950s bear an eerie resemblance to the current haggling over international and doinestic policy, as if a new generation of national security actors were still reading froin the yellowed scripts of its Eisenhower-era predecessors.

Froin the perspective of arms control, a community that has witnessed stunning revolutions in weapons teclinology, military strategy, and Cold War politics, not inuch has changed on the agenda of issues relating to Open Skies. The Bush administration echoes the traditional hitany of benefits that a treaty might offer: the amelioration of worries about the possibility of surprise attack, the hopes for an intelligence bonanza froni new access to the Soviet Union, and the eagerness to put newfound Soviet opemiess to the test. At the same time, the traditional downside risks of arms control are just as apparent today as they ever were: can we really trust the Soviets to comply; dare we afford thein this degree of access to our secret installations and our advanced observation teclinology; and is the operation really worth the financial costs?

From the perspective of constitutional law-a realin that has likewise experienced contortions of doctrine and upheavals of precedent-

349. Id; see also National Treasury Employees' Union v. Von Raab, 489 U.S. 656 (1989) (partially affirming court of appeals' decision to vacate an injunction ordered by district court to prohibit mandatory drug testing of government employees); Megapulse, Inc. v. Lewis, 672 F.2d 959 (D.C. Cir. 1982) (permitting injunction against government disclosure of conmercial trade secrets); National Org. for Reform of Marijuana Laws v. Mullen, 608 F. Supp. 945, 962-63 (N.D. Cal. 1985) (granting injunction against state and federal narcotics control agents performing warrantless searches with low-flying helicopters).

350. Marshall v. Barlow's, Inc involved administrative searches undertaken by OSHA to investigate comphance with various federal statutes regulating workplace safety. When the Court determined that the inspection program was so broad as to apply to all businesses engaged in interstate commerce, it declared inapplicable the reduced scrutiny applied to "pervasively regulated industries." When judged by the standards of ordinary fourth amendment protections, the warrantless inspections were improper, and the Court sustained the injunction. Marshall, 436 U.S. at 313-14.

351. See Tanzman, supra note 138, at 63-66 (considerable congressional controversy has surrounded efforts to develop a federal statute to restrict remedies for constitutional violations); Tanzman \& Kellman, Legal Implementation of the Multilateral Chemical Weapons Convention: Integrating International Security with the Constitution, 22 N.Y.U. J. INT'L L. 475 (1990) (regarding constitutional imphications of neasures to apply "pervasive regulation" to the chenical industry). 
the underlying issues are also the same as they always have been: how to perform the delicate balancing act required to preserve individual hiberty in an ordered society. The challenges of national security, and the opportunities seemingly offered by Open Skies, inake that precarious balance even inore visible and unavoidable. As the Supreme Court noted in a different context, "[i] $t$ would indeed be ironic if, in the name of national defense, we would sanction the subversion of one of those liberties . . . which niakes the defense of the Nation wortliwhile."352

Perhaps it is only an illusion to suggest that we have inade inuch progress in either sector. There has certainly been vast inovement in both arms control and constitutional law over the past thirty-five years, but are we as a society any inore free and safe than we were when Eisenhower and Khrushchev debated the issues that now bedevil Bush and Gorbachev? This Section offers a series of observations about the degree of advanceinent in both arms control and jurisprudence.

\section{A. Progress in Arms Control}

Regarding Open Skies in particular, three observations are in order. First, a comprehensive multilateral agreement would be both pohtically and militarily useful at this time. Politically, Open Skies could provide a timely symbol of good faith, a vivid demonstration of the world's commitnient to finding mutually acceptable solutions to common security problems by casting aside old reservations. Militarily, aircraft carrying advanced sensors could provide proinpt, regular, low-altitude surveillance, efficiently supplementing satellite observation.

Second, Open Skies, at least in its current format, could be implemented in the United States consistently with the strictures of the fourth amendment. The slim nuajority that produced Ciraolo and Dow was inaintained im Riley, ${ }^{353}$ and the primciples enunciated are not likely to unravel in the near future. When the sensors employed are no inore imvasive or powerful than sophisticated visible-hight pliotography, aerial reconnaissance is not a "search," whether accomplished by airplane or by helicopter, undertaken on a routine patrol or with a directed focus, or targeted at a domicile or a factory. Where Open Skies negotiators seek to progress beyond that level of surveillance, the constitutional infirmities will grow, and no one can confidently predict how future courts will react to infrared, radar, particulate, or magnetic sensors. A best gness is

352. United States v. Robel, 389 U.S. 258, 264 (1967) (discussing the first amendnent freedonı of association).

353. It may be noteworthy that Riley, decided in 1989, produced only a four-Justice plurality decision, with Justice O'Connor's concurrence providing the fifth vote. Vigorous dissents by Justices Brennan and Blackmun echoed the earher dissents in Ciraolo and Dow. Commentators have also criticized the Court's current position as inconsistent with Katz See, e.g., 1 W. LAFAVE, supra note $169, \S 2.3(\mathrm{~g})$, at $420-23$. 
that courts, in support of high-level foreign pohicy, would find soine way to sustain those intrusions. Nevertheless, the more vigorous the sensors, the more stringent will be the constitutional scrutiny.

Third, the uncertainty of judicial precedent requires that current negotiators tailor an Open Skies treaty to meet the demands of our Constitution as well as the constitutions of the other parties. By anticipating fourth amendment difficulties, the diplomats may be able to rescue those portions of the treaty they most ardently seek. For exainple, they should avoid SIGINT sensors, and they should consider procedures to safeguard the interests of commercial secrecy and domiciliary privacy. If negotiators can minimize the threat of unfamiliar, invasive sensors and strengthen protections against abuse, courts will receive the treaty more favorably.

Beyond those specifics, the confrontation between Open Skies and the fourth ainendment prompts two more generalized observations about the future progress of conteinporary arms control. First, this investigation proves that there can, indeed, be too much of a good thing. Effective verification is certainly essential for arms control; if Open Skies can enhance America's eyes and ears in monitoring potentially threatening activities inside the Soviet Union and elsewhere, it will significantly promote interuational peace and security. But at some point the undaunted pursuit of verification becoines self-defeating; if taken to excess, our fascination with technological gimmickry and pohtical transparency can undercut real progress toward the security they were originally intended to support. Both the Soviet Union ${ }^{354}$ and the United States ${ }^{355}$ have jumped on the bandwagon of untimited verification, but both should now pause to consider the direction in which that vehicle is pointed.

Future arms control accords will inevitably einbrace verification provisions that would have seemed unthinkable ouly a few years ago, let alone in 1955. The provisions envisaged for agreenients on strategic nuclear arms, conventional forces, and chemical weaponry will inake all modern inspection precedents seem primitive by comparison. ${ }^{356}$ Conversely, the threats of industrial espionage, coinpromise of official secrets, and invasion of personal privacy will also intensify.

354. See Statement by Eduard Shevardnadze, supra note 118, at 3, reprinted in VESTNIK, at 60 (Soviet foreign minister Shevardnadze stated that "as far as verification measures are concerned, these can never be im excess. . . . I would even risk suggesting the following formula: sufficiency in arms, and an excess of verification measures.").

355. Statement by U.S. Secretary of State James A. Baker III, supra note 121, at 4 (calling for an Open Skies treaty that would accord parties "the right to use any technology that will do the job").

356. See Morrison, supra note $\mathbf{9 5}$, at $\mathbf{2 5 8 0}$ (predicting that the current United States capabilities for conducting on-site inspections of the Soviet Union will be dwarfed by future arms control assignments). 
This consideration, in turn, leads to a second generally applicable lesson of the ongoing experience with Open Skies negotiations. In most previous arms control efforts, the negotiating states have insisted upon a tight link between the substantive limitations on arms and the supporting verification or inspection provisions. A single agreement or treaty, such as the new Treaty on Conventional Forces in Europe, ${ }^{357}$ has governed both the quantitative or qualitative restrictions on weaponry, and the procedures and mechanisms that confirm compliance with those restrictions. ${ }^{358}$ Open Skies would, for the first time, sever that link.

Breaking the link between disarmament and verification provides greater flexibility because it enables arms controllers, in an appropriate case, to put elements of the inspection process into place im advance of the substantive restrictions. ${ }^{359}$ Creative use of "confidence-building measures" unaccompanied by arms reductions can immediately reduce the mutual fears of surprise attack and pave the way for more substantial reductions at a later stage. ${ }^{360}$ Breaking the link, however, also deprives the inspection process of its core rationale, and critics may ask why the negotiating states are creating an expensive and cumbersome apparatus if it does not lead to any immediate tangible savings or arms reduction. With the link severed, the mspection system can begin to look too much like a fishing expedition, with insufficient connection to the real world of armanients. This severing process can be especially problematic in situations like Open Skies, where the advent of judicial proceedings may prompt sliarpened imquiry into the true extent of the governinent's stake in the intrusions, the possibility of minimizing the burdens innosed upon the citizens, and the opportunities for balancing the conflicting interests in a different way.

357. The CFE Treaty, supra note 7 , follows the usual pattern, providing, in a single set of documents, for the arms reductions and the associated verification arrangements.

358. See Common Security: A Programme for Disarmament, The Report of the INDEPENDENT COMMISSION ON DISARMAMENT AND SECURITY ISSUES 134-37 (1982) (arguing for greater openness on military matters, but also for a close link between the scope of any arms control treaty and its means of verification).

359. For example, it may be wise for countries to negotiate and implement an early agreement on effective systems for momitoring the production of a category of weaponry, even before the states have reached consensus upon the ultimate numbers of those arms that each side will be permitted to possess. This type of preliminary verification measure would facilitate a substantive agreement by reducing opportunities for undetected cheating and by testing the power of the verification system.

360. In the various sets of negotiations concerning military activities in Europe, for example, the states have sometimes found it convenient to separate the deliberations about real reductious in troops, tanks, and aircraft from the negotiations concerning "associated measures" tlat could build confidence in the military stability of the region. Kirk, Verifying a CFE Agreement, Issue Paper publislied by the Ameriean Association for the Advancement of Science, Program on Science, Arms Control, and National Security, at 10-11 (Jan. 1990). 


\section{B. Progress in Constitutional Law}

The meaning of the fourth amendment, a single laconic sentence that has spawned countless cases and volumes of commentary, remains obscure and uncertain even in its core areas. ${ }^{361}$ The restriction upon government inquiries imposed by the fourth amendment has been retrenched, with its tenuous logic muddied, by recent decisions of the Supreme Court. ${ }^{362}$

It is clear that courts will defer to the executive in the formulation and implementation of foreign policy, and a reference to national security will automatically ehcit substantial, ${ }^{363}$ although not necessarily con1plete, ${ }^{364}$ deference. There is, however, no persuasive logic for this unusual judicial self-restramt; it is impossible to predict when the Court will step back, citing the need to avoid embarrassing the executive, ${ }^{365}$ and when the Court will instead play a more active role, denigrating any "talismamic incantation"366 of the foreign affairs power by the President.

More importantly, fourth amendment cases have consistently exposed the need for the law to keep pace with the relevant technology. Restrictions upon government imvestigations should grow apace with the officials' ability to launch new types of probes into the citizens' lives. ${ }^{367}$ The fourth amendment, rooted im concerns about the Enghish kings sending soldiers to rifle through patriots' papers, ${ }^{368}$ has evolved into a bulwark agamst all manner of modern scientific intrnsions. Wiretapping, electromic surveillance, aerial reconnaissance, and a host of other monitoring techniques unknown to the founding fathers have come withm the ambit of the fourth amendment ${ }^{369}$ as courts have struggled to adapt

361. See Amsterdam, supra note 216, at 349, 395.

362. See generally Wasserstrom, supra note 187, at 119-30 (describing the gradual weakening of fourth amendment protections by the Supreme Court, from the Warren Court to the present).

363. See Dames \& Moore v. Regan, 453 U.S. 654 (1981); Umited States v. Butenko, 494 F.2d 593, 608 (3d Cir.), cert. denied, 419 U.S. 881 (1974).

364. See Halperin v. Kissinger, 606 F.2d 1192, 1200-01 (D.C. Cir. 1979) ("The Court has not demied the reality of dangers from foreign or internal conflicts. Rather, it has recognized the need to respect constitutional requirements even in troubled times."), aff'd in part, cert. dismissed in part, 452 U.S. 713 (1981).

365. See United States v. Curtiss-Wright Export Corp., 299 U.S. 304, 320-21 (1936).

366. United States v. Robel, 389 U.S. 258, 263 (1967).

367. See, e.g., California v. Ciraolo, 476 U.S. 207, 214 (1986) ("[Sincel Justice Harlan's observations [in Katz v. United States, 389 U.S. 347, 362 (1967), about future electronic developments and the potential for electronic interference with private communications . . . the Court has required warrants for electronic surveillance ...." (citations omitted)).

368. See Payton v. New York, 445 U.S. 573, 583-85 \& n.21 (1980).

369. See Florida v. Riley, 488 U.S. 445, 462 (1989) (Brennan, J., dissenting) ("If indeed the purpose of the restraints imposed by the Fourth Amendment is to 'safegnard the privacy and security of individuals' then it is puzzling why it should be the hehcopter's noise, wind, and dust that provides the measure of whether this constitutional safegnard has been infringed."); United States v. White, 401 U.S. 745, 756 (1971) (Douglas, J., dissenting) ("Electronic surveillance is the greatest leveler of human privacy ever known. How nost forms of it can be held 'reasonable' within the 
eighteenth-century language to twentieth-century conditions. ${ }^{370}$ As future technological advances increase the potential for further assaults upon the privacy of the citizenry, the fourth amendinent's protection must continue to apply. ${ }^{371}$

\section{Final Thoughts}

This study of an intersection between arms control and constitutional law suggests that stretching either disciphine to cover new sectors may jeopardize the disciplines theinselves. The stretching reveals gaps both in the fabric of the fourth amendment and in the logic of national security negotiations. Precedents suggest that each subject has only tenuous stability even within its central domam; as each ventures into new spheres, its conventional wisdom is undercut.

We should therefore be wary of novel opportunities, even if they coine dressed in benigu first appearances. The fourth amendinent exists, after all, to guard against excesses sponsored by our own government, and the case law warns us to be attentive even to "the obnoxious thing in its mildest and least repulsive form."372 "Experience should teach us to be inost on our guard to protect liberty when the Government's purposes are beneficent. ... The greatest dangers to hiberty lurk in insidious encroachınents by men of zeal, well-meaning but without understanding. $\$ 373$

An Open Skies treaty can avoid these pitfalls, and can make a

meaning of the Fourth Amendment is a mystery."); Olmstead v. Umited States, 277 U.S. 438, 475-76 (1927) (Brandeis, J., dissenting) ("Whenever a telephone line is tapped, the privacy of the persons at both ends of the line is imvaded. . . As a means of espionage, writs of assistance and general warrants are but puny instruments of tyranny and oppression when coinpared with wiretapping."); Dean v. Superior Court, 35 Cal. App. 3d 112, 116, 110 Cal. Rptr. 585, 588 (1973) ("The Fourth Amendment guards the privacy of human activity from aerial no less than terrestrial mvasion.... Reasonable expectations of privacy may ascend into the airspace and claim Fourth Amendment protection."). But see Katz v. United States, 389 U.S. 347, 365 (1967) (Black, J., dissenting) ("The second clause of the [Fourth] Amendment ... establishes its Framers' purpose to limit its protection to tangible things. . . A conversation overheard by eavesdropping, whether by plain snooping or wiretapping, is not tangible and . . . can neither be searched nor seized.").

370. See, e.g., Dow Chem. Co. v. United States, 536 F. Supp. 1355, 1368 (E.D. Mich. 1982) ("[T]he Constitution and Bill of Rights are not to be read as covering only the technology known in the 18th century." (quoting U.S. v. White, 401 U.S. 745, 756 (1971) (Douglas, J., dissenting))), rev'd, 749 F.2d 307 (1984), aff'd, 476 U.S. 227 (1986).

371. See Amsterdain, supra note 216, at 386, 396. To some extent, the coverage accorded by the fourth amendinent has varied according to the wealth and lifestyle of the target population: those who cannot afford thick-walled, air conditioned housing have had to conduct their daily affairs in a fashion that is more visible to their neighbors and also to the inquiring eye of the (warrantless) police. Id. at 404. Open Skies would, in this context, be a "leveler," simce it could look into private lives of all citizeus alike, whether in multi-family or single-family honsing, or whether out in the open or surrounded by high walls and shrubs.

372. Boyd v. Umited States, 116 U.S. 616, 635 (1886).

373. Olmstead v. United States, 277 U.S. 438, 479 (1927) (Brandeis, J., dissenting); see also Skinner v. Railway Labor Executives' Ass'n, 489 U.S. 602, 635 (1989) (Marshall, J., dissenting) 
worthwhile contribution to national security and international stability. The fourth amendment can accommodate this new challenge and opportunity, stretching this far-but not nuch farther-to embrace the new investigations. 